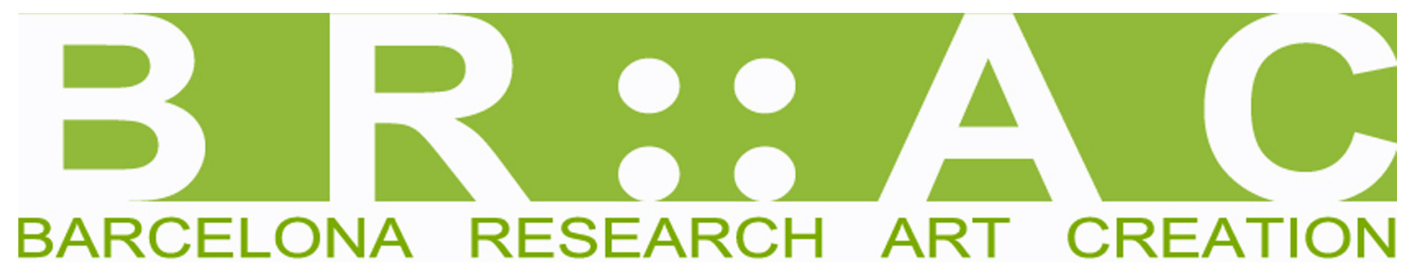

\title{
Volume 1, Number 2
}

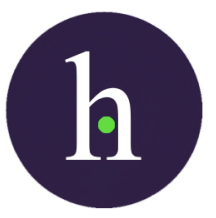

Metaverso y artista - David Serra Navarro - 130

Joc, treball i art. Els pragmatistes de Chicago i la construcció de formes Articles socials d'experiència democràtica - Núria Sara Miras Boronat - 153

Apuntes sobre la enseñanza de la escultura en México Francisco Javier Tous Olagorta - 175

Las voces y el cine invisible - Joaquim Cantalozella y Marta Negre - 203

Review

Conxita Boncompte, "Iconografia picassiana (1905-1907). Influencia de la pintura pompeiana”. Goya, núm. 335 (2011), pp. 156-179 Mireia Freixa - 228 
Instructions for authors, subscriptions and further details:

http://brac.hipatiapress.com

\section{Metaverso y artista}

David Serra Navarro ${ }^{1}$

1) Departamento de Filología y Comunicación. Universitat de Girona, España.

Date of publication: October 3rd, 2013

To cite this article: Serra Navarro, D. (2013). Metaverso y artista. BRAC Barcelona Research Art Creation, 1(2), 130-152. doi: 10.4471/brac.2013.06

To link this article: http://dx.doi.org/104471/brac.2013.06

\section{PLEASE SCROLL DOWN FOR ARTICLE}

The terms and conditions of use are related to the Open Journal System and to Creative Commons Non-Commercial and Non-Derivative License. 
BRAC - Barcelona Research Art Creation. Vol. 1 No. 2, October 2013

pp. $130-152$

\section{Metaverse and Artist}

David Serra Navarro

Universitat de Girona

\section{Abstract}

This paper shows an interpretation of the virtual world Second Life through their artistic actions, especially based on the code performance notion, questioning and reflecting on the medium itself. A cross view to make visible the main focus of interest of the metaverse in an approximation of aesthetic analysis, and understanding the creative dispersion that seemingly aimless transits and is manifested in a virtual body.

Keywords: Virtual body, Second Life, relational aesthetics, virtual object, code performance 
BRAC - Barcelona Research Art Creation. Vol. 1 No. 2, October 2013

pp. $130-152$

\section{Metaverso y Artista}

David Serra Navarro

Universitat de Girona

\section{Resumen}

El siguiente artículo muestra una interpretación del mundo virtual de Second Life a través de sus acciones artísticas, especialmente desde la noción code performance, cuestionando y reflexionando sobre el propio medio. Una visión transversal que quiere hacer visible los principales focos de interés de dicho metaverso en una aproximación de análisis estético, y entender su dispersión creativa que transita aparentemente sin rumbo y que se manifiesta en un cuerpo virtual.

Palabras claves: Cuerpo virtual, Second Life, estética relacional, objeto virtual, code performance 
L Los mundos virtuales constituyen un nuevo foco de atención para los creadores de contenidos, pero también suponen un nuevo medio a explorar desde su vertiente artística y sus posibilidades expresivas. La diversidad y complejidad de estas plataformas que configuran los entornos virtuales en línea nos ofrecen un amplio abanico de peculiaridades, estableciéndose como nexo común las características de corporeidad, interactividad y persistencia. Nuestro interés, por este medio transversal y el individuo que lo habita, lo delimitaremos sobre el metaverso ${ }^{1}$ de Second Life. Linden Lab es la corporación responsable de esta propuesta, mostrada al público en el año 2003 bajo la dirección de Philip Rosedale y el determinante asesoramiento de Jaron Lanier y Lawrence Lessig, Second Life promueve una política de contenidos en la que sus usuarios tienen el control de la propiedad intelectual de sus obras, hecho más que significativo para explicar una estimulación creativa en la producción de objetos virtuales. En consonancia, este mundo virtual que funciona con divisas reales, se nutre económicamente del tránsito y consumo virtual, siguiendo un modelo meritocrático en el que sus usuarios también ven recompensadas sus contribuciones. De esta manera, sumergirnos en su posible esfera artística implicará conocer la disolución del «objeto artístico» en un sistema de intercambios y transacciones simbólicas, pero a su vez integrado como un elemento de mercado y lenguaje.

Si bien podemos categorizar la actividad artística del metaverso en función del producto resultante, acercándonos a términos como el hyperformalism de Dan Coyote ${ }^{2}$, la práctica machinima ${ }^{3}$ o la code performance de Gazira Babeli ${ }^{4}$, se sugiere una visión alternativa que pueda dibujarnos un escenario de esta realidad artística que fluye entre la estética, la ética y la política del entorno virtual en cuestión.

\section{La imagen-cuerpo}

Abordar la imagen que discurre en tiempo real $^{5}$ significa entender el objeto virtual como una extensión del cuerpo, y una negociación del sujeto entre lo virtual y su significado. En este sentido, en el proceso de 
transferencia de cuerpo a «objeto-cuerpo», nos lleva a interpretar la figura del artista bajo dos posicionamientos vinculados a la estética relacional de Nicolas Bourriaud. Primeramente como un «semionauta» que navega entre signos y con los que crea nuevas conexiones, pero también como un signo más de este universo. Por lo tanto, este enfoque quiere ser una muestra de apertura conceptual, un planteamiento en el que no se discrimine la producción virtual en función de su apariencia, sino que interconecte la deriva cultural de Second Life a través de subjetividades virtuales y lenguaje. Como nos señala Mike Featherstone (2007), el tramado cultural de imágenes y signos saturan la sociedad, y hacen de la vida un consumo estético que rompen los límites entre arte y vida cotidiana, dándose así una reestructuración de la producción y fuerzas productivas que sitúan las relaciones sociales en el mismo plano de lo económico. En paralelo, siguiendo las argumentaciones de Roy Frankenberger (2008), en que nos describe nuevos modelos de gobernabilidad a raíz de un cambio de poder dominado por la economía de signos y un sentido estético globalizado, nos trasladamos de nuevo sobre la gestión individualizada de la producción de sentido; en este caso retomando el contexto social en el que se inician los procesos de significado-contenido, en una constante revisión del «yo-avatar» en relación al entorno. Así pues, el siguiente artículo pretende reflexionar la interacción en un entorno virtual singular mediante la praxis artística, tomando la performance como eje central en el que el sujeto cuestiona su nuevo cuerpo como instrumento de comunicación y de expresión artística.

\section{Code performance y acción mimética}

Paradójicamente, en un mundo sin restricciones físicas, la copia de lo real marca un itinerario visual en el imaginario de Second Life; ya sea en sus paisajes que clonan grandes ciudades, en sus habitantes bípedos, en la negación de la ingravidez o en sus productos humanizados. La retroalimentación entre ambos mundos se extiende mediante la imagen, conduciéndonos a unas relaciones sociales mediatizadas por la imagensignificado, y que posiblemente nos reflejen la noción de espectáculo de Guy Debord (1967). La simulación parece llenar el inventario de cada avatar, y su producción nos refleja parte de la experiencia depositada en 


\section{David Serra Navarro - Metaverso y artista}

cada usuario, adoptando formas, objetos y prótesis más propias del mundo real que del metaverso. No obstante, en esta manipulación colectiva en la que impera la imagen de lo real, ¿hay cabida para nuevos lenguajes?

Una de las prácticas artísticas más determinantes en la resolución de este interrogante se encuentra en la noción code performance; tal acción consiste en trasladar en Second Life la reproducción real de la acción del cuerpo, a modo de happening, ahora mediante un alter-ego que se inscribe en un entorno virtual. Aparentemente esta es otra modalidad de mímesis, talmente como un performer virtual en el que su nuevo cuerpo se manifiesta como soporte y material artístico, y que nos apunta hacia un catalizador de la condición humana en la perspectiva social y simbólica, su fenomenología existencial y el concepto de biopoder de Foucault (Scheper-Hughes 1994, p. 232). No obstante, en esta concepción del cuerpo como elemento que fluctúa en el espacio y el tiempo, y lugar en donde construir una identidad en relación al otro, no podemos comprender la performance desde la fisicalidad y el dolor a que puede verse sometido el cuerpo; se pierde su dimensión material y se actúa en la descorporeidad. Qué sentido adquieren en el plano virtual las acciones de los artistas Chris Burden, Marina Abramovic o Stelarc?

Tomemos por ejemplo la performer Sigalit Landau en Barbed Hula ${ }^{6}$ (2000), cuyas cicatrices nos remiten a la supresión del ritual y al deseo de ser liberado de las restricciones sociales; mientras, imaginemos su avatar homólogo, el cual sólo recreará el deseo de acercarse a la realidad. En la misma línea, sin riesgo físico, el salto al vacío de Yves Klein (Le Saut dans la Vide, 1960) se desnaturaliza en otro mensaje; ahora el individuo ingrávido está condenado a no lastimarse, a persistir en un bucle sin otro fin que la desconexión de la red. Como nos señala Claudia Giannetti (2003), introduciéndonos en otro concepto paralelo:

El público se transforma en voyeur de su propia metaformance, a la vez que se disipa la división clara entre el cuerpo remoto o telepresente y el cuerpo físico real, ya que el interactor pasa a existir (virtualmente) en y entre ambos lugares. (p.216) 


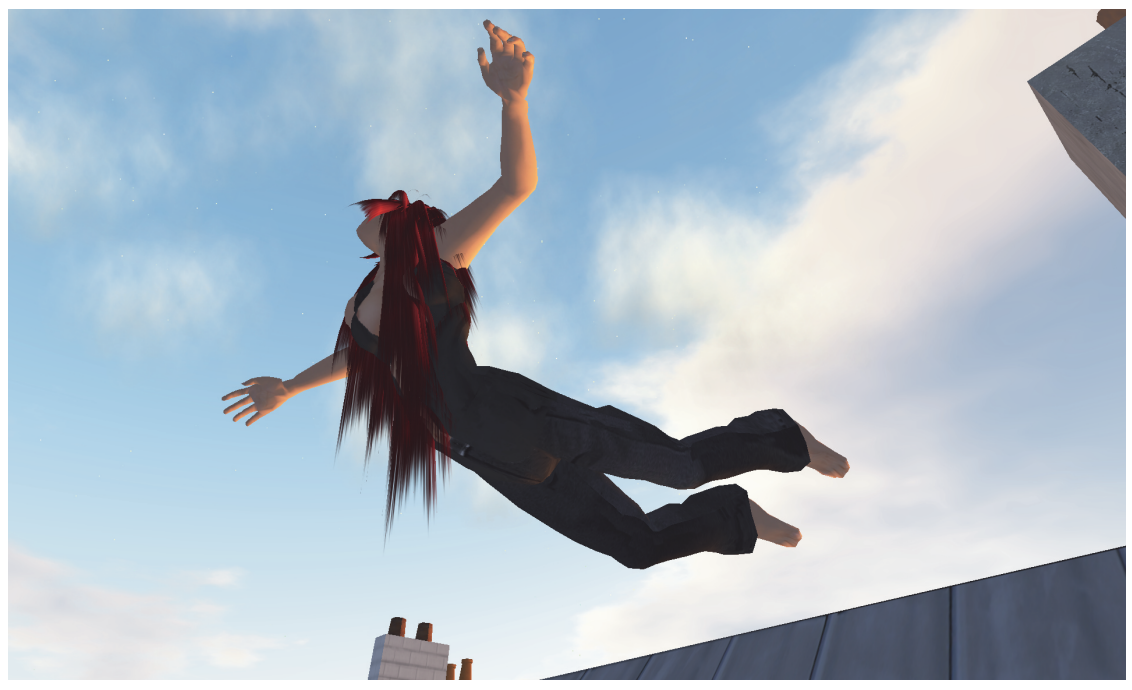

Figure 1. Yves Klein tribute, Kenneth Russo 2010. Esta captura de interfaz corresponde al proyecto Culdesac Island del artista Kenneth Russo, concretamente la imagen muestra un usuario utilizando el código abierto que replicaba la acción de Yves Klein, reviviendo una experiencia inalcanzable e ironizando sobre la condición del avatar. Fuente: Kenneth Russo.

La producción code performance del universo de Linden Lab puede suscitarnos una deriva cultural de creaciones dispersas y efímeras, sin embargo, como figura icónica de esta praxis, cabe citar la obra iniciada en el año 2006 de la artista virtual Gazira Babeli. Sus aportaciones no residen en clonar la historia de la performance, sino en cuestionar el propio medio y el propio cuerpo virtual. Babeli añade una significación a los límites del lenguaje corporal virtual, juega con la plasticidad de la identidad, y reinventa al artista en un marco aún por explorar. Entre sus obras más determinantes encontramos Avatar on Canvas (2007), Come Together (2007) o Ursonate in Second Life - Monument to Kurt Schwitters (2007); un conjunto de propuestas que se muestran al espectador tanto en formato código como en formato objeto, interpelando la experiencia de éste y convirtiéndole en parte del medio, en un «espectactor» (Boal, 1980). Según Domenico Quaranta (2010, p. 
160-175), Gazira Babeli es en ella misma un proyecto artístico, una identidad en un universo simulado, y en esencia el resultado de la manipulación y subversión de los códigos. De esta manera, sumándose a este modo de experimentación virtual popularizado por Babeli, nos encontraremos en paralelo con otros artistas y colectivos que ven en Second Life una alternativa para desenvolver nuevas experiencias: China Tracy con su obra i.Mirror (2007) para la 52 ${ }^{\mathrm{a}}$ Bienal de Venecia, en la que se documentan desde la idea belleza los excesos de consumo y capitalismo virtual; Eva y Franco Mattes con sus Synthetic Performances (2007) reviviendo a Joseph Beuys o Vito Acconci en el metaverso; o incluso el propio Stelarc con Avatars have no organs (2009), una performance que integrará realidad y virtualidad para describirnos un nuevo estadio del cuerpo sin subordinaciones biológicas y una amplificación de la experiencia.

\section{Devenir objeto en movimiento}

En el momento en que el usuario accede a desdoblarse en un nuevo ente virtual, frecuentemente bípedo y con rasgos importados de la realidad, se está produciendo un contrato simbólico y cultural en el que se rompe la dicotomía sujeto-tecnología; un producto final que se materializa en la interfaz, un acto de comunión entre aquello virtual y aquello real. Como nos señala Zygmunt Bauman (2003), en una sociedad "líquida", individualizada y simultáneamente interconectada, se nos aparece constantemente un duelo entre la libertad y la comunidad. La tensión entre lo colectivo y lo personal, nos presenta y representa un juego de procesos de socialización dentro de un imaginario colectivo vivido paradójicamente en el protagonismo individual. En esta colisión de lo virtual y de lo real se inicia la intersubjetivización del individuo, convertido en parte del flujo de información que transita modificando los sentidos del propio medio. Cabe señalar que la intersubjetivización puede considerarse como una extensión de la subjetivización (Traugott, 2003, p. 134), un mecanismo de reclutamiento de significados y que en el este caso el "nuevo individuo" adoptará como herramienta comunicativa. En otras palabras, el sujeto controla su experiencia desde un nuevo ángulo de la realidad, y su vehículo es el cuerpo virtual: un 
objeto de significación cambiante. Del face-to-face al object-to-object, un nueva forma de comunicación vinculada a un diseño de entorno virtual, en este caso el mundo de Second Life.

Por lo tanto, la figura del artista performativo bajo esta óptica nos sugiere una posición de reencuentro, de "participación mágica" (Maffesoli, 2009), que replantea el presente y lo cotidiano en el "movimiento" solitario y compartido. Recordemos a Susanne K. Langer, en su libro Feeling and Form (1953), abordaba la noción de las artes visuales como espacios virtuales en los que: "Una imagen no es en realidad más que un "objeto" exclusivamente virtual. Su importancia radica en el hecho de que no la utilizamos para que nos guíe hacia algo tangible y práctico, sino que la tratamos como una entidad completa que sólo tiene relaciones y atributos virtuales, nada más; todo lo que es, está en su forma visible» (1953, p. 48). Ahora la imagen somos nosotros, tomamos su presencia como un estado de consciencia que nos ayudará a construir nuevos modelos de realidad a través de la participación. Una "imagen-objeto-en movimiento" que supera desde la interactividad la separación cuerpo-mente, y que nos muestra una reestructuración de nuestra percepción y pensamiento, acogiéndose en un nuevo estado del cuerpo como instrumento de intercambio.

El metaverso proporciona la hipermediación y la hibridización de la información, es el paso de la metáfora a la metonimia que disipa lo teatral para entrar en un juego común marcado por la acción del individuo. Esta idea, en que lo dinámico fija un posicionamiento vital, nos aproxima a un amplio marco de trabajo en el que lo imaginario adquiere un valor añadido de realidad; la hipermediación entendida como la inmersión del sujeto en los métodos interactivos de escritura y su relación en distintos grados de significación. Ya no se delimita mediante la representación, el objeto-cuerpo nos permite movernos y sentirnos dentro de aquello intersticial, artístico. En el "analogon" de Second life parece que todo sucede en la pantalla, así cabe diferenciar varios niveles de interacción y una gran variedad de objetos que configuran este entorno; la gradación empieza por el objeto estático persistente y termina en el objeto-cuerpo, dejando entre los dos extremos prótesis, dispensadores, algoritmos con funcionamiento autónomo, o prototipos de inteligencia artificial que derivan por el espacio. Sin embargo, delante esta clasificación objetual no podemos 
olvidarnos de su componente social en el que de forma inmersiva se escenifican una serie de prácticas rituales, vertebrando un juego que une multiplicidades de experiencias y que crea sentido de comunidad. Comprender el nuevo yo significa descubrir el propio entorno, y esta realidad conducida mediante lo performativo como vía de liberación se desenvuelve en un contexto liminal. Victor Tuner nos describía:

«...liminality represents the midpoint of transition in a statussequence between two positions, outsiderhood refers to actions and relationships which do not flow from a recognized social status but originate outside it, while lowermost status refers to the lowest rung in a system of social stratification in which unequal rewards are accorded to functionality differentiated positions» (1974, p. 237)

De esta manera, Second Life se puede entender como una interfaz asociada al espacio liminal, un canal de transición en el que se potencia la experiencia del cuerpo. Una estrategia de construcción de experiencia común, en la dispersión y en la fluidez; talmente como una fusión del teatro y lo ritual que nos acerca a la idea de Jerzy Grotowski de comunicación espiritual, una ceremonia que lleva a los "espectadores" a la catarsis mediante el trabajo (acción) del actor. En esta línea, José Antonio Sánchez nos apunta:

El cuerpo subjetivo mantiene una potencialidad movilizadora que incrementa su eficacia en sociedades marcadas por la hipermediación y la teatralidad generalizada. La movilización puede producirse como acción, situación, recorrido o encuentro $\mathrm{y}$ contribuir desde la co-presencia a pensar nuevos modos de relación (2009, p. 8)

El vínculo del cuerpo como objeto de negociación nos transmite una escena compartida de consumo de experiencias, una unidad social que impulsivamente utiliza el movimiento para desarrollar su identidad. 


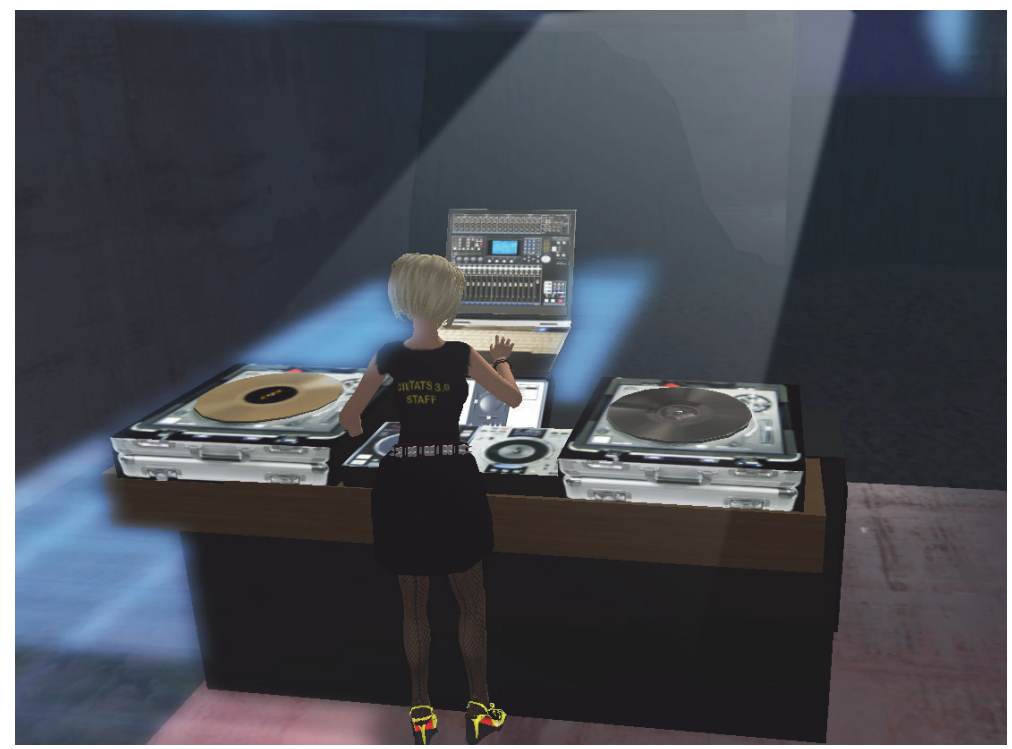

Figure 2. Avatar DJ en sala virtual. Posiblemente la escenificación de las raves sea una de las manifestaciones más gráficas en que cultura, cuerpo e identidad se funden en modo ritual. Estas acciones de baile frenético suelen reproducirse en el marco de Second Life, tomando de nuevo el cuerpo como protagonista. Fuente: Kenneth Russo.

\section{Ecosistema económico y contributivo}

A diferencia de los populares servicios de redes sociales, la plataforma de Philip Rosedale, Second Life, no basa su negocio interno en la acumulación de usuarios, apropiación de contenidos e impacto publicitario. Su política defiende la propiedad intelectual de cada residente virtual, o dicho de otra manera, el trabajo puede convertirse en recompensa. Si bien el incentivo más visible es el económico, también se contemplan unos valores meritocráticos hacia la contribución de conocimiento. Un ejemplo que simplificaría esta lógica pudiera ser la creación de un "objeto-prótesis" que pese a un valor económico nulo (freebie) se difundiera entre la comunidad, ya sea como expresión estética compartida (moda), o reconocimiento hacia su autor. 


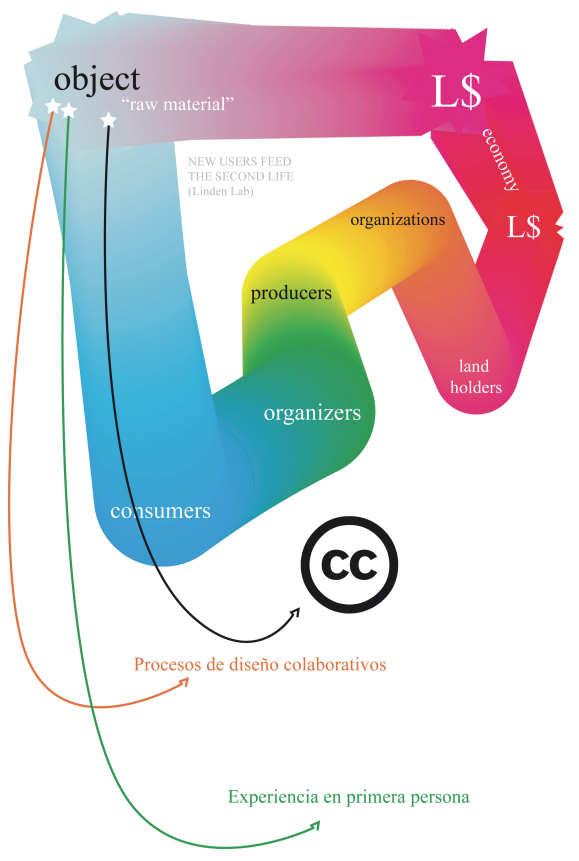

Figure 3. Esquema de retroalimentación económica del medio. El objeto virtual es una pieza clave en el engranaje de negocio, pero también es la herramienta que confiere actividad creativa al usuario. Fuente: autor.

Bajo estas directrices, basadas en motivar la creación de objetos, se nos plantean varias visiones sobre el tipo de producción individual: el objeto como mercancía, el objeto como anexo al cuerpo y/o el objeto como delimitador del espacio. ¿Dónde situar el cuerpo? Quizás las posibilidades funcionales de los objetos vayan más allá de esta simplificación clasificatoria, no obstante se nos dibuja un panorama en el que la imagen es la mediadora comunicativa y el organismo avatar le proyecta velocidad, tiempo real. Las creaciones se acumulan en todos los rincones del metaverso, en los supermercados automatizados, en los inventarios de los avatares o inmortalizadas en las instantáneas de los usuarios; en definitiva son el alfabeto que les permite articular significado. Esta realidad, y no ficción, desencadena un conjunto de 
procesos relacionales en los que el cuerpo no se queda al margen. Lo performativo es el motor que pone en circulación lo creado, unos valores comunicativos que impregnan cada cuerpo de forma cambiante, popular y sin otra restricción que la libertad de elección de su portador. De nuevo libertad y comunidad son los dos ejes que sacuden al alter-ego en un continuum que debe gran parte de sus sinergias al diseño del medio, una singularidad en la red. Por lo tanto el artista de la acción se acaba mezclando con la acción de la comunidad, y sus contribuciones se hibridizan entre códigos, objetos e imaginario colectivo.

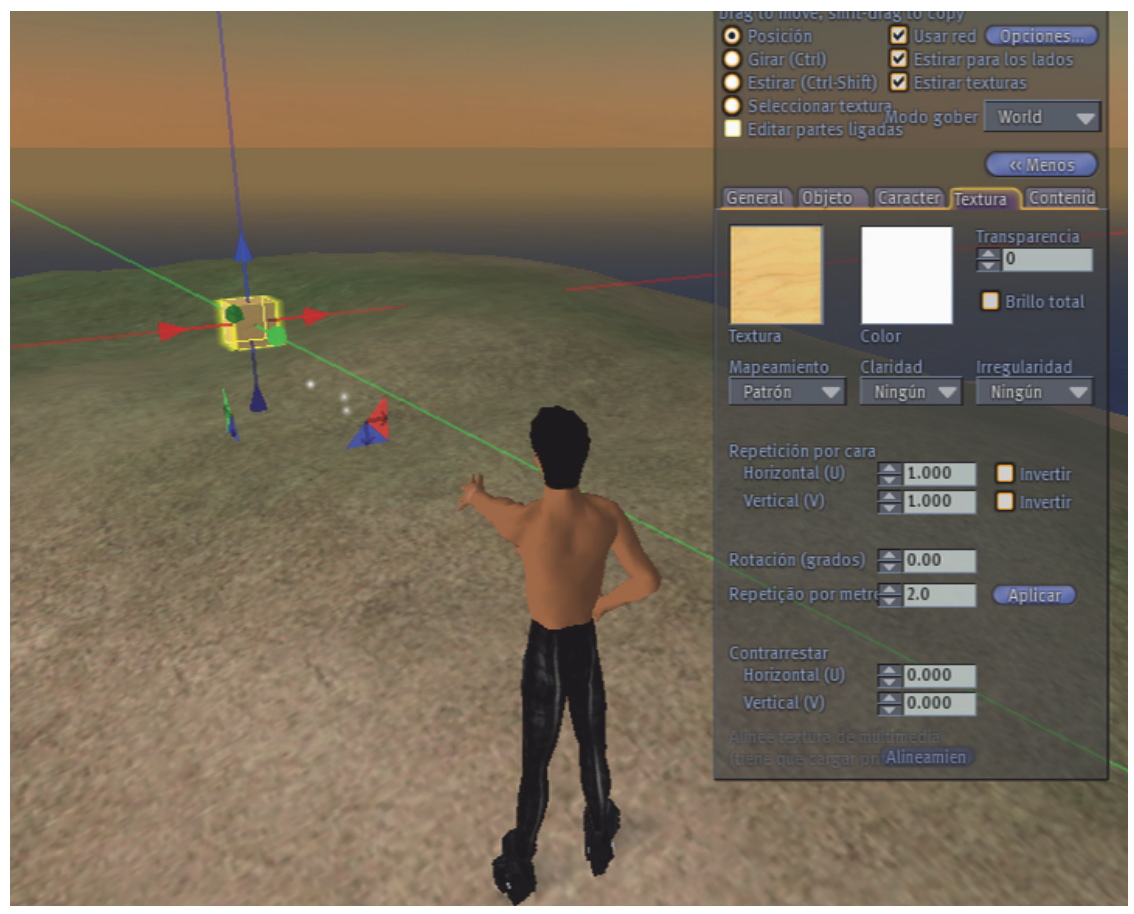

Figure 4. Avatar creando objeto en un sandbox. Second Life proporciona de forma abierta un gestor-modelador 3D de contenidos, en el que los residentes acceden de manera intuitiva, y que no precisa grandes conocimientos de programación LSL (Linden Script Language). El sistema también ofrece la posibilidad de acceder a múltiples bibliotecas y tutoriales de programación más compleja. Fuente: autor. 


\section{El cuerpo contenedor}

No sería del todo objetivo decir que en Second Life existe libertad para crear en cualquier terreno, sólo los propietarios previo pago pueden depositar y exhibir sus objetos. Esto significa que se crea una limitación de posibilidades hacia los usuarios que no disponen de suficientes recursos económicos para comprar suelo virtual con dinero real. Sin embargo, en esta jerarquía que repercute en la modelación del paisaje, encontramos unas zonas llamadas arenales (sandboxes) que cumplen una función muy específica, permitir el desarrollo creativo y el testeo algorítmico bajo una limitación de tiempo. Es decir, son unos espacios de experimentación abiertos, pensados para promover el talento y la actividad productiva, pero con una persistencia de pocas horas. Se puede crear pero no se puede exponer, con lo que probablemente el "producto" nunca será encontrado durante el transcurso de una exploración del lugar. Son objetos efímeros. La única manera que se contempla para salvaguardar este material es trasladarlo dentro del inventario (disco duro interno del registrado) o anexarlo a una parte del cuerpo, utilizando la superficie de la anatomía como una prolongación del suelo virtual. Precisamente en esta última peculiaridad, que inicialmente responde más a una cuestión técnico-empresarial de cómo gestionar y optimizar los privilegios de un objeto, nos encontramos con un nuevo soporte expositor: el cuerpo.

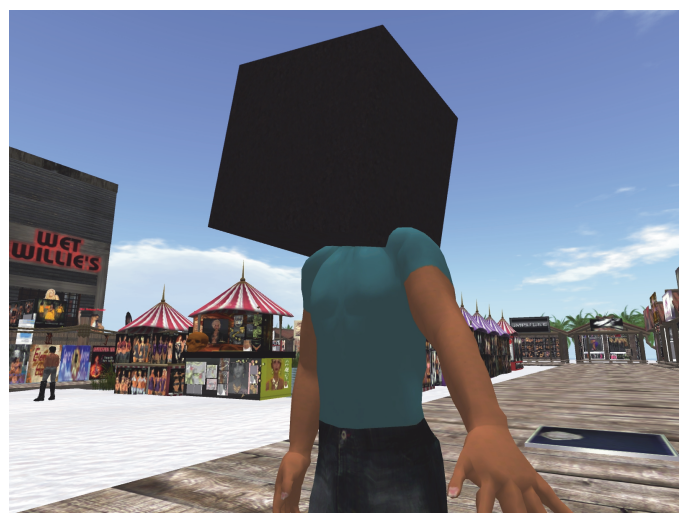

Figure 5. Objeto anexado en cabeza. Los objetos pueden fusionarse en cualquiera de las partes anatómicas del avatar. Estos polígonos base (prims) modifican la apariencia del usuario y establecen nuevas formas de comunicación visual. Fuente: autor. 
Cada avatar utiliza su representación para desplazarse, pero también como portador de los objetos virtuales cuyos autores no poseen privilegios de owner (generalmente en manos de otras corporaciones). La cuestión es que más allá del terreno virtual el cuerpo amplifica su capacidad estrictamente de representación, ya que nos sugiere un propio entorno de investigación semiótica en el que indagar los límites de nuestra proyección. En este sentido, Douglas Rushkoff nos señala: «Our digital experiences are out-of-body. This biases us toward depersonalized behavior in an environment where one's identity can be a liability» (2010, p. 79). Por esta razón, el foco de estas metaestructuras de lenguaje convergen en un yo abstracto, en formación y rizomático; un contorno pixelado que no puede detenerse y que se cuestiona a sí mismo en su línea de tiempo. En consonancia, retomando la obra de Gazira Babeli Come Together, una performance en que los cuerpos virtuales de los espectadores se fusionaban con el propio performer, nos delata este estado cambiante; un cuerpo que nos fuerza a interrogarnos sobre nuevas relaciones entre el sujeto y el mundo en su sentido más amplio. El artista conoce el poder de la acción, pero su "obra" se nutrirá de la interrelación con los procesos metacognitivos de los usuarios que le rodean; en este caso usuarios que aprehenden de, y con, su cuerpoavatar.

\section{Participación}

Poniendo en duda la libertad de los usuarios, desde una perspectiva de la estética normalizada del metaverso, se nos aparecen una serie de acciones subversivas que "combaten" las normas del propio medio. Son actos de resistencia, de manifestación, de contestación social, y que responden al uso del nuevo cuerpo como instrumento de agitación virtual. Muestras de resistencia simbólica que raramente se pueden trasladar al mundo real, y que por esta misma razón dotan de sentido el vínculo avatar-entorno. Frecuentemente, y tomando de referencia el pionero grupo de performers Second Front ${ }^{6}$ (2006), nos encontramos con diferentes estrategias comunicacionales basadas en el mensaje irónico y en la representación metafórica. Tal como nos define la declaración de artista de Liz Solo, miembro del colectivo Second Front, 
sus influencias provienen de: «...numerous sources, including Dada, Fluxus, Futurist Syntesi, the Situationist International and contemporary performance artists such as Laurie Anderson and Guillermo GomezPena, Second Front creates score-based performances and interventions that challenge notions of traditional performance, virtual embodiment and the culture of immateriality». ${ }^{7}$

Un dato que nos lleva a interpretar el metaverso más allá del tráfico de información, que nos induce a interrelacionar consciencias cambiantes que hablan a través de su cuerpo, de un mundo corporal y relacional. Un cuerpo que se opone a un metaverso construido a base de mezclas de fragmentos independientes de realidad, y que unifica relacionalmente la superficie que simula en el entorno. Lo subversivo es visualizar los procesos de producción cognitiva, la pantalla es el cuerpo. Este fenómeno está directamente unido a las nuevas formas sociales de consumo digital, transformando los papeles del espectador $\mathrm{y}$ despertando nuevas audiencias que quieren formar parte de la propia acción. Como nos apuntaba Sara Diamond, las nuevas tecnologías nos piden otra forma de diálogo con el mundo:

«..technology is a material force: while social, cultural and economic structures shape technology, technology also acts back on social, cultural, economic and physical bodies. The materiality of technology and of the image (which acts not only on language but as a language on us) are in constant tension..» (Diamond, 1996, p. 134).

Una producción cultural que se encadena con formas de consumo identidario (Featherstone, 2007), y que afirma al propio sujeto en la individualidad. La performance consumida, desde el cuerpo y en el cuerpo ("exocuerpo digital"), nos construye narraciones en la interconsciencia de un inevitable ser humano que vive y persiste, pero que también convive en la acción. Se trata de la creación de un marco sociocultural articulado, un espacio de creación de formas culturales y un consumo de experiencias que el mundo material no puede satisfacer. Cada avatar determina su destino en un mundo igualitario sin desventajas socioeconómicas (Kelly, 2004, p. 62-63). La disolución de 
las fronteras, en un encuadre ubicuo y simultáneamente autónomo en las experiencias en primera persona, que toman lo performativo como propagador de nuevas realidades. Una forma de arte que se extiende en modo de metacognición, que refleja y se refleja en una realidad rizomática de procesos vitales. En esta sintonía, rescatamos la figura de Nicolas Bourriaud y su entendimiento relacional:

La globalización es económica. Punto. El arte sólo sigue los contornos de ella, porque es el eco, más o menos lejano, de los procesos de producción [...] el arte no procede por imitación de procedimientos y modos contemporáneos, sino según un juego complejo de resonancias y resistencias que a veces lo acerca a la realidad concreta, otras lo aleja hacia formas abstractas, o arcaicas. [...] El arte da cuenta de la evolución de los procesos productivos en su globalidad, de las contradicciones entre las prácticas, de las tensiones entre la imagen que una época crea de sí misma y la que proyecta realmente. En una época en que las representaciones se interponen entra la gente y su vida cotidiana, o entre los seres humanos mismos, es absolutamente normal que el arte se aleje a veces de la representación para transformarse en una parte de la realidad en sí. (Bourriaud, 2009, p, 177)

La estética relacional concibe la realidad material de la forma como relacional, ya que la experiencia formal de la relación produce realidad; es decir, según Bourriaud no hay existencia real sin la interacción, que es la que promueve las formas democráticas de participación artística. Dejando atrás la contemplación y la función de almacenamiento cultural, esta teoría relacional nos acerca a un campo más amplio, en el que el arte está incluido pero que se despliega la forma globalmente. En esta línea José Luís Brea nos señala: «...la energía simbólica que moviliza la cultura está empezando a dejar de tener un carácter primordialmente rememorante, recuperador, para derivarse a una dirección productiva, relacional. [...] Para en cambio convertirse en esa herramienta mediante la que inteligimos el mundo colectivamente.» (Brea, 2007, p. 5). 
Esta visión del mundo articulado culturalmente entra en sincronía con la definición de Félix Guattari y Gilles Deleuze de la obra de arte como bloques de perceptos y de afectos, que revisada en clave actual encuentra en la complejidad de las nuevas tecnologías un nuevo tipo de forma-mundo. En la convergencia arte-ciencia-tecnología se nos presenta el concepto espacio-tiempo como lugar practicable. Tiempo interactivo, tiempo del perpetuum mobile, que interferirá en la imagen en el tiempo de anunciación de esta; aquello virtual subvertirá el registro tradicional del tiempo, y el espacio será el resultado de esta actualización constante. Al trasladarnos en el metaverso, esta reflexión estética no se producirá sobre la forma instrumental o representativa, sino sobre las transformaciones e hibridaciones en la poética de aquello tecnológico. Un proceso a través de la imagen digital interactiva confiere sentido a los objetos. Por lo tanto, el cuerpo es el portador de la acción, interactiva, instantánea, y que dará pie a un sistema activo de captación y evolución de la información. El cuerpo como un fluir en el medio, y que cuestiona al spect-actor mediante prácticas perfomativas las dicotomías natural-artificial o naturaleza-cultura, estableciéndose como un lenguaje propio que modela nuevos modelos de comunicación no verbal, que implica a otros cuerpos, y que en su vertiente de fuerza comunicante construye nuevos códigos. Otra particularidad del cuerpoavatar es que el usuario reviste su apariencia para mostrarse al mundo pero también para definirse en el mundo, talmente como un voyeur de su propia representación. Así pues, se actúa a partir de una imagen del signo que se desearía ser, olvidando el espejo de Lacan en que el usuario se representaría creyendo que es. Una muestra de transitoriedad, de movimiento, y comportamiento social, que en ojos de Gilles Lipovetsky podría interpretarse como "la moda que teje sociedad":

«We have reached the era of consummate fashion, the extension of the fashion process to broader and broader spheres of collective life. Fashion is not so much a particular peripheral sector, now, as a general form at work in society as a whole. Everyone is more or less immersed in fashion, more or less everywhere.» (Lipovetsky, 1994, p. 131). 


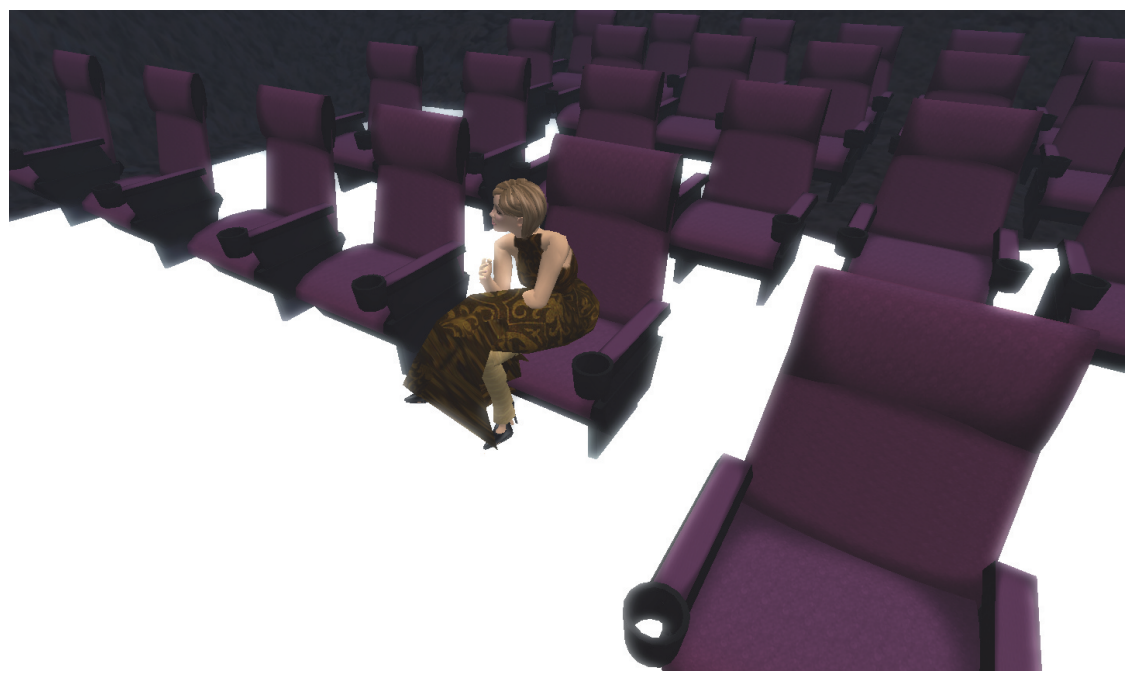

Figure 6. Avatar en sala de proyección vacía. Los espacios del metaverso establecen una relación de intersubjetividad con el usuario, no obstante es en la relación concreta cuerpo-espacio donde se interpela al usuario. Fuente: autor.

Lo participativo, el encaje y diálogo de los cuerpos, fundamenta la acción artística y las negociaciones de sentidos. En la acción deviene un intercambio simbólico, otra experiencia, que como nos describe Rosanne Stone: «Penetrating the screen involves a state change from the physical, biological space of the embodied viewer to the symbolic, metaphorical consensual hallucination of cyberspace; a space that is a locus of intense desire for refigured embodiment.» (Stone, 2000, p. 522). El metaverso nos proporciona otro contexto para expandir nuestro cuerpo, y salvando las distancias la performance nos remite a una estética interactiva que no siendo material se abraza a la idea duchampiana de vida, o al sentido vital de las composiciones de John Cage, tomando al "otro" que se escapa del simulacro. De forma concisa, Diana Domingues nos apunta:

El ciberarte, por la interactividad, demanda la presencia del cuerpo en acción. Sus interacciones generan ambientes vivos. Así, es una 
forma de arte que estrecha sus relaciones con la vida, reforzando la premisa duchampiana de aproximar el arte a la vida. En las interacciones no es más el objeto que interesa, sino un campo de relación que se realiza en estados imprevisibles, de regeneraciones y que ocurre entre el cuerpo y las tecnologías, en una "zona de intervalo" donde algo acontece y que no podría existir sin la presencia y acción del cuerpo con las tecnologías con las cuales está interactuando.» (Domingues, 2000, p. 7).

Interacción y sistema son nodos claves de un proceso abierto de cocreación de experiencias en un medio transmedia, induciendo a producir nuevos relatos en comunidad y desde el cuerpo-nodo. La cuestión es que nuestra "presencia" adquiere un nuevo envolvente dentro esta caja escénica que es Second Life, una ilusión que sólo puede llevarnos al significado comprendiendo el estado intersticial del medio; la acción se diluye en códigos, y la figura del performer se nos aparece en la pantalla en luz-objeto que confiere pequeños fragmentos de realidad a "otros" interactuantes-luz. Nos situamos en un punto medio, en una zona de contacto, en un cuerpo-interfaz que reclama su camino errático mediante el movimiento. La inmanencia propia de las experiencias tintadas de lo tecnológico nos destapan un nuevo conocimiento, y un nuevo modelo vida para los sujetos; un giro radical que Scott Lash nos describirá de la siguiente manera: "Culture is displaced into an immanent plane of actors attached or interfaced with machines. Now we experience cultural things not as trascendental representations, but instead as immanent things: as objects, as technologies» (Lash, 2002, p. 9).

\section{Comunicación y objeto}

El código, el que posibilita nuestro alter virtual, es una herramienta de subversión que encarna un poder simbólico a través de su representación objetual. Nuestro avatar no sólo representa, sino que presenta un modo de actuación, estableciéndose una negociación entre nuestra identidad en formación y el objeto virtual que lo esculpe ante 
nuestros ojos. La batalla de estas aproximaciones artísticas no tiene lugar en el cuerpo individual fenomenológico, su atractivo se perfila como un proceso fusión entre lenguaje y límites relacionales; una convergencia entre el objeto semiótico y la subjetividad virtual de quién decide controlarlo. Por esta razón, sin categorizar, y sin ahondar en la dispersa especificidad de la producción virtual, intuimos como el medio Second Life deviene un espacio-tiempo intersticial en el que desarrollarse artísticamente. Más allá de una comunidad en red, el metaverso se articula como un laboratorio social en el que sus usuarios utilizarán su nuevo cuerpo-objeto para comunicarse, interactuar y descubrir conexiones entre ambos mundos. Sin ánimo de quitar importancia a los nuevos ismos que surgen en este entorno, ya que demuestran un amplio repertorio de expresiones y fragmentos significantes, en su análisis global, el signo en tiempo real nos delata otra visión del escenario artístico más cohesionado y más ubicuo. Con esta visión de pájaro, y dejando atrás muchos otros elementos no circunstanciales, como el valor económico del signo, se nos despliega un océano a medio camino entre lo real y lo virtual; un espacio para explorar en primera persona y vivirlo en clave real, ya sea definiendo una extensión de nuestro cuerpo, comprendiendo nuevas relaciones con el mundo o preguntándonos si realmente la contribución del artista en Second Life es difundir conocimiento. Todo desde la acción, el cuerpoacción del metaverso.

Quizás el salto al vacío no ha hecho más que empezar, hacia un futuro incierto en que se diluyen nuevas formas relacionales de entender y habitar el ciberespacio estéticamente.

\section{Notas}

${ }^{1}$ El término metaverso se identifica con la idea de universo paralelo, y proviene de la novela Snow Crash de Neal Stephenson (1992); también se utiliza habitualmente para describir la visión del trabajo en espacios 3D totalmente inmersivos.

2 Véase trabajos de Dan Coyote en línea: http://www.dancoyote.com/ Recuperado el 9 de mayo de 2011.

${ }^{3}$ El machinima, contracción de los términos machine y cinema, hace referencia a un género audiovisual que utiliza generalmente los gráficos de los videojuegos como elementos de una narración. Se constituye como un espacio donde confluye cine, 
animación y juego; una animación que es capturada en tiempo real en un entorno virtual.

4 Véase trabajos de Gazira Babeli en línea: http://www.gazirababeli.com/WORKS.php Recuperado el 10 de junio de 2010.

5 Hay que precisar que la idea de tiempo real en Second Life está condicionada por el tiempo de reacción de sus servidores, siendo en muchos casos más una intención que una realidad. Véase los términos asociados: rezzing $i$ derezzing en: http://secondlife.wikia.com/wiki/Rez Recuperado 10 de julio de 2012.

6 Véase video en línea: http://www.videoartworld.com/video_66.html Recuperado 14 de julio de 2011.

7 Véase integrantes del grupo (entre ellos Gazira Babeli) y documentación en línea de sus performances en: http://www.secondfront.org/index.html Recuperado el 4 de febrero de 2012.

${ }^{8}$ Véase Artist's Statement en página web personal de Liz Solo:

http://www.lizsolo.com/secondfront.html Recuperado el 7 de febrero de 2012.

\section{Referencias}

Bauman, Z. (2003). Comunidad. En busca de seguridad en un mundo hostil. Madrid: Siglo XXI.

Boal, A. (1980). Stop: c'est magique! Río de Janeiro: Civilização Brasileira.

Bourriaud, N. (2006). Estética relacional. Buenos Aires: Adriana Hidalgo.

Bourriaud, N. (2009). Radicante. Buenos Aires: Adriana Hidalgo.

Brea, J. L. (2007). Cultura RAM, Mutaciones de la cultura en la era de su distribución electrónica. Barcelona: Gedisa.

Debord, G. (1967). La société du spectacle. Paris: Les Éditions Gallimard (1992).

Diamond, S. (1996). Technology matters: material issues in the information age. En: Peter White (ed) Naming a Practice, Curatorial Strategies for the Future (Banff: Walter Phillips Gallery Editions, 1996).

Domingues, D. (2000). Cibercultura, creación e interactividad. En:

FERLA, Jorge La. (Org.). De la pantalla al arte transgénico.

Buenos Aires: Livros del Rojas - Universidad Buenos Aires.

Featherstone, M. (2007). Consumer Culture and Postmodernism. 2nd

Edition. London, Thousand Oaks, New Delhi: SAGE

Publications.

Frankenberger, R. (2008, 25 de junio). Learning from Baudrillard and 
Foucault: Consumer Culture, Social Milieus and the Governmentality of Lifestyle, $31^{\mathrm{a}}$ conferencia anual ISPP, París. Giannetti, Cl. (2003). Arte humano/máquina: virtualización, interactividad y control. En: Hernández Sánchez, D. Arte, cuerpo, tecnología. Ediciones Universidad Salamanca, p. 216.

Graham, E. L. (2002). Representations of the Post-Human: Monsters, Aliens, and Others in Popular Culture. New Brunswick, NJ: Rutgers University Press.

Kelly 2, R.V., (2004). Massively Multiplayer Online Role-Playing Games. North Carolina, USA: McFarland \& Company, Inc. Langer, S. K. (1953). Feeling and Form: A Theory of Art. New York: Charles Scribner's.

Lanier, J. (2010). You are not a gadget: A manifesto. New York: Alfred A. Knopf.

Lash, S. (2002). Critique of Information. London: Sage.

Lessig, L. (2004). Free Culture: How Big Media Uses Technology and the Law to Lock Down Culture and Control Creativity.

Recuperado el 3 de mayo de 2008, de www.jus.uio.no/sisu/free_culture.lawrence_lessig/portrait.pdf Lipovetsky, G. (1994). The Empire of Fashion: Dressing Modern Democracy. Trad. Catherine Porter. Princeton: Princeton Univ. Press.

Maffesoli, M. (2009). El reencantamiento del mundo. Una ética de nuestro tiempo. Buenos aires: Dedales.

Quaranta, D. (2010). Media, New Media, Postmedia. Milano: Postmediabooks.

Rushkoff, D. (2010). Program or Be Programmed. Ten Commands for a Digital Age. New York: OR Books.

Sánchez, J. A. (2009). Teatralidad y Cultura Visual. Revista 0000. Museo Reina Sofía: Madrid, pp. 8-11.

Scheper-Hughes, N. (1994). Embodied Knowledge: Thinking with the Body in Critical Medical Anthropology. En: Assessing Cultural Anthropology. Rob Borofsky, ed. New York: McGraw-Hill. Serra, D. (2012). Culdesac Island [194/204/21]. Girona: Documenta Universitaria.

Stone, R. A. (2000). En: Bell, D.; Kennedy, B.: The cybercultures 
152 David Serra Navarro - Metaverso y artista

reader. London: Routledge.

Traugott, E. C. (2003). From subjectification to intersubjectification. En:

Raymond Hickey (ed.), Motives for Language Change. Cambridge:

Cambridge University Press, pp. 124-139.

Turner, V. (1974). Dramas, Fields, and Metaphors: Symbolic Action in

Human Society. Ithaca, NY: Cornell University Press.

David Serra Navarro es Profesor Visitante de la Universitat de Girona, Departamento de Filología y Comunicación UdG. España.

Contact Address: Universitat de Girona. Departamento de Filología y Comunicación. ST. DOMÈNEC. Plaza Ferrater Mora 1. 17071 - GIRONA. España. E-mail address:

david.serranavarro@udg.edu 
Instructions for authors, subscriptions and further details:

http://brac.hipatiapress.com

\section{Joc, Treball i Art. Els Pragmatistes de Chicago i la Construcció de Formes Socials d'Experiència Democràtica.}

Núria Sara Miras Boronat ${ }^{1}$

1) Universität Leipzig, Alemanya / Seminari de Filosofia Política de la Universitat de Barcelona (SFP-UB).

Date of publication: October 3rd, 2013

To cite this article: Miras Boronat, N. (2013). Joc, Treball i Art. Els Pragmatistes de Chicago i la Construcció de Formes Socials d'Experiència Democràtica. BRAC - Barcelona Research Art Creation, 1(2), 153-174. doi: 10.4471/brac.2013.07

To link this article: http://dx.doi.org/10.4471/brac.2013.07

\section{PLEASE SCROLL DOWN FOR ARTICLE}

The terms and conditions of use are related to the Open Journal System and to Creative Commons Non-Commercial and Non-Derivative License. 
BRAC - Barcelona Research Art Creation. Vol. 1 No. 2,

October 2013 pp. 153-174

\section{Play, Work, and Art. The Chicago Pragmatists on Constructing Social Forms of Democratic Experience}

Núria Sara Miras Boronat

Universitat de Barcelona

\section{Abstract}

G.H. Mead stated in 1896 that there are three general types of human activity: work, play and art. Play, work and art are the cornerstones of the kind of social experience the Chicago pragmatists (Mead, Dewey and Addams) had in mind and the basis of any democratic education. These are also three ways to enrich and diversify the patterns of social interaction in any given community, the social conditions for which keep changing in a social environment with growing complexity. The first aim of the paper is to present the conception of game and play due to G.H. Mead as intrinsically linked to the other two types of human activity. The second aim of the paper is to critically examine the possibilities for a pragmatist social philosophy in the current global world.

Keywords: play, work, art, pragmatism, social philosophy, democracy, pluralism, social justice. 
BRAC - Barcelona Research Art Creation. Vol. 1 No. 2,

October 2013 pp. 153-174

\section{Joc, Treball i Art. Els Pragmatistes de Chicago i la Construcció de Formes Socials d'Experiència Democràtica}

Núria Sara Miras Boronat

Universitat de Barcelona

\section{Resumen}

En 1986 Mead apuntó que existen tres tipos generales de actividad humana: el trabajo, el juego y el arte. Juego, trabajo y arte son las piedras angulares de la clase de experiencia social que los pragmatistas de Chicago tenían en mente y la base para cualquier educación democrática. También son tres modos de enriquecer y diversificar los modos heredados de interacción social para cualquier comunidad dada, modos cuyas condiciones han ido variando en entornos sociales de creciente complejidad. El primer objetivo del artículo será presentar la concepción de juego debida a G.H. Mead, intrínsecamente vinculado a los otros dos tipos de actividad humana. El segundo objetivo del artículo será el de examinar críticamente las posibilidades de la filosofica social pragmatista para el actual mundo globalizado.

Palabras claves: juego, trabajo, arte, pragmatismo, filosofía social, democracia, pluralismo, justicia social. 


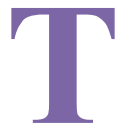

ot $\mathrm{i}$ que el joc ha estat sempre part de la vida humana en tot temps i cultura, el seu significat antropològic ha estat tradicionalment ignorat per la filosofia occidental com a quelcom marginal, frívol i poc digne d'atenció. No obstant això, importants metàfores i usos del concepte de joc ens haurien de venir a la memòria com quelcom força habitual en la història del pensament. Recordem, per exemple, l'enigmàtic fragment B52 d' Heràclit on es parla del temps com un nen que juga als daus, recuperat per la doctrina cosmològica de l'amor fati de Nietzsche (Fink, 1993), les reflexions de Plató a les Lleis sobre els homes com a joguines dels déus, l'aposta de Pascal o els jocs de llenguatge de Wittgenstein. El joc s'ha demostrat com un model útil per fer entenedors conceptes abstractes i fugissers com el funcionament de les convencions socials, la creativitat o el poder implacable de l'atzar sobre una existència, finita $i$ exposada a l'arbitrarietat de poders inabastables per a les criatures humanes (Sutton-Smith, 2003; Runkel, 2003, González, 2006). D’aquest concepte de joc en podríem dir, provisionalment, un concepte instrumental ja que la seva funció és, en primera instància, posar-se al servei d'altres fenòmens o conceptes. L'estudi substantiu del joc com a fenomen primàriament $\mathrm{i}$ ineludiblement humà va haver d'esperar encara, però, a les primeres dècades del segle XX.

Afortunadament, l'estudi del joc va començar a intensificar-se a la dècada dels seixanta i gaudeix avui dia d'una bona salut, sobretot pel que fa a la recerca empírica. Una gran varietat de disciplines s'ocupen del joc, de manera que aquest tòpic mostra una envejable interdisciplinarietat comparat amb altres temes de recerca en la ciència social. Els diferents aspectes del joc com a pràctica social poden fer asseure a la mateixa taula a sociòlegs, matemàtics, pedagogs, treballadors socials, medicina esportiva, filòsofs i especialistes en intel-ligència artificial. Alhora, el joc s'està fent cada cop més present en tots els dominis de la nostra vida social. D'aquest fenomen en va alertar, amb un tint força irònic ja l' historiador de la cultura holandès Johan Huizinga amb el seu Homo Ludens (1938). Avui dia, molts especialistes dels recent estrenats Game Studies parlen de gamification, com l'ús del joc, sobretot del videojoc en altres dominis de la vida social ${ }^{1}$. Per tant, sembla necessari retornar sobre les diverses dimensions 
d'interacció social i les seves connexions. Pioners en aquest camp van ser els pragmatistes nord-americans de l'Escola de Chicago. En les següents apartats provarem d'exposar breument la seva teoria dels tres tipus d'activitats humanes en conjunció amb la seva utopia social democràtica. Després passarem a fer-ne una valoració crítica, tot provant d'avaluar-ne els mèrits i les virtuts per un món cada cop més opac, si no més lúdic.

\section{El concepte de joc i la visió pragmatista de la filosofia}

Abans d'introduir el concepte pragmatista de joc, caldria fer una referència general al que es considera l'herència filosòfica de l'Escola de Chicago, sobretot el que és comú a les seves tres figures més rellevants: John Dewey (1859-1952), George Herbert Mead (18631931) i Jane Addams (1860-1935). La tesi que defensarem aquí és que l'Escola de Chicago tenia com a un dels seus principals objectius posar a la pràctica una teoria de l'experiència social democràtica que es basava en una combinació harmònica entre el treball, el joc i les arts. El pilar d'aquesta teoria era una vocació eminentment pedagògica en almenys dos sentits. Primer, perquè havia de servir d'orientació en la confecció dels currícula escolars. Segon, perquè aspirava a esdevenir una pedagogia social que impliqués més enllà de l'escola a la resta d'institucions i agents socials.

El concepte de joc que es vol exposar en aquest article és el fruit de la col-laboració per anys entre aquestes tres grans figures de l'Escola de Chicago. No obstant això, em centraré principalment en la figura de Mead per dues raons. Primer, perquè l'enfocament de Mead és més sistemàtic i filosòfic. Segon, perquè els conceptes de game $i$ play ${ }^{2}$ elaborats per Mead tenen un significat central per a la constitució de la subjectivitat (Mead en diu self ${ }^{3}$ ) en la seva obra més important, el llibre pòstum Mind, Self and Society (1934). El paper de Dewey i Addams en l'elaboració d'aquests conceptes no s'ha de menystenir i tot i que és difícil calibrar-ne els efectes pel caràcter de l'escriptura de Mead i la circumstància de la publicació pòstuma de la majoria de les seves obres. Per això ens agradaria recordar aquí alguns fets rellevants relacionats. John Dewey pot ésser considerat el filòsof de l'educació dels Estats Units d'Amèrica, engegant un moviment molt influent anomenat 
"progressive education" (Westbrook, 1991; Pinhard, 2009). De Jane Addams en podríem dir que era la força executora del pragmatisme de Chicago: una dona d'acció compromesa amb la reforma social. La Hull House que ella va fundar amb altres el 1889 continua funcionant sota les mateixes directrius fins avui ${ }^{4}$. La Hull House va ser important no només per la introducció de la filosofia del kindergarten de Friedrich Fröbel als Estats Units ${ }^{5}$, sinó també per haver allotjat anarquistes, marxistes, teòrics socials, artistes i altres crítics del capitalisme industrial, la defensa de la igualtat entre gèneres, el treball socioeducatiu dins la comunitat d'immigrants i la promoció de la diversitat cultural. Podem apreciar com totes aquestes funcions se sintetitzen en pamflets escrits per Addams com A Plea for More Play, More Pay and More Education for Our Factory Girls and Boys (1914) o Recreation as a Fundamental Element for Democracy (1913) de la seva col-laboradora Mary McDowell (Deegan, 1999). Jane Addams va rebre fins i tot el Premi Nobel de la Pau el 1931 i va gaudir d'una vasta fama internacional. Però justament el seu compromís públic amb el pacifisme i el seu feminisme militant la situen en un lloc incòmode per la teoria política nordamericana. Per aquestes raons considerem que no se li ha donat el lloc que li correspon en el sí del pragmatisme nord-americà en particular i en la filosofia social en general ${ }^{6}$.

Addams, Dewey and Mead eren molt actius en el servei a la comunitat $\mathrm{i}$ coneixien de primera mà les dures condicions de vida als settlements de Chicago ${ }^{7}$. Una de les seves principals preocupacions era que el treball a la fäbrica estava per sota d'un nivell mínim de dignitat humana que capacités als treballadors i els permetés expressar tots els interessos i valors centrals per a les seves vides. L'ideal de vida pragmatista implica una visió integral de la vida humana on comunitat, universitat, ciutadania, escola, família i govern treballen pel benefici de tots. Per tant, caldrà dir alguna cosa més sobre aquesta primera fornada ${ }^{8}$ de pragmatistes nord-americans com a escola filosòfica per entendre en quin context de pensament s'insereix aquesta fenomenologia de les activitats humanes. Aquest moviment filosòfic va ser fundat per Charles Sanders Peirce ${ }^{9}$ i prosseguit per pensadors com John Dewey i George Herbert Mead. Com el mateix nom suggereix, el "pragmatisme" és una teoria que neix i té el seu fi últim en la praxis humana. L'escola, principalment radicada a Amèrica, es va fer ràpidament molt popular. 
Se sap que les xerrades divulgatives de William James, sense anar més lluny, aplegaven centenars de persones desitjoses de conèixer la última moda filosòfica de la mà del catedràtic de psicologia de la universitat de Harvard. Però l'escola no va ser immune a la crítica. En poc temps el "pragmatisme" va ser simplificat pels seus detractors, que l'equiparaven sense més ni més a la difusió ideològica dels fins del capitalisme industrial nord-americà. Aquesta va ser la primera recepció predominant a Alemanya i la Gran Bretanya (Russell, 1966). Més endavant, alguns dels pragmatistes més fervorosos acabaren per refusar el terme, tot proposant alternatives potser més precises, però menys engrescadores com "pragmaticisme" (Peirce) o "empirisme radical" (James). Amb això i tot, la seva obra segueix sent un referent pragmatista.

Quines són les tesis que defensa el pragmatisme com a filosofia? El que tots els pragmatistes tenen en comú, sobretot en la seva variant clàssica, és la reavaluació del concepte filosòfic d' experiència. L'ús que els pragmatistes en fan pretén anar més enllà de l'empirisme tradicional $\mathrm{i}$ acollir tots tipus d'experiència (natural, moral, artística, religiosa $\mathrm{i}$ mística) per evitar el reduccionisme a la mera dada no elaborada i captada pels sentits. La importància del concepte d'experiència es pot resseguir en els títols de les obres principals del pragmatisme clàssic, per exemple: Experience and Nature (1925) i Art as Experience (1934) de John Dewey; o The Varieties of Religious Experience (1902) de William James. L'experiència mai és absoluta o donada d'una vegada per totes, sinó que es presenta sempre d'una forma discreta $\mathrm{i}$ fragmentada. Per tant, la tasca metodològica i epistemològica més important serà la de la reconstrucció (Dewey, 1920). El món dels pragmatistes consisteix no "en les coses ja fetes, sinó en procés", per citar un passatge famós de A Pluralistic Universe de William James (James, 1987, p. 751) ${ }^{10}$. Donat que l'experiència, la matèria primera del coneixement, és quelcom encara per fer i per consumar, l'epistemologia pragmatista serà, conseqüentment, fal-libilista (afirma que el nostre coneixement ha de ser sotmès a prova i revisat periòdicament) $i$ pluralista (sosté que hi ha tantes formes de coneixement com fonts d'experiència, James, 1907). La teoria del coneixement pragmatista té alhora una implicació pràctica. Els pragmatistes comparteixen la profunda convicció que l'experiència social tampoc s'ha d'acceptar tal i com ens ve donada sinó que ha de ser modelada i millorada per tal de 
preparar el terreny a la democràcia per venir ${ }^{11}$. La democràcia real (que no la democràcia actual) estarà arrelada en un ethos democràtic que és un mode de vida que proveeix les condicions perquè cada individu pugui desenvolupar les seves capacitats i participar activament en la vida política de la seva comunitat ${ }^{12}$.

El credo pragmatista s'identifica sovint amb el credo liberal. Però en aquest article ens agradaria presentar el pragmatisme de Chicago com una oportunitat perduda per construir una modalitat d'experiència social que seria més igualitària $i$ pluralista $i$ que podria estar en millors condicions d'oferir oxigen en el nostre atapeït i dens món globalitzat. "Experiència social" s'usa aquí encara de forma general per referir tot tipus d'activitats $\mathrm{i}$ interaccions entre agents socials en una societat donada. És encara prou vague i general per encabir tot tipus d'accions a nivell descriptiu. D'altra banda, "experiència social" té una avantatge important des del punt de vista de l'epistemologia social. L'experiència és quelcom dinàmic $\mathrm{i}$ amb història (Dewey, 2005), alhora quelcom mal·leable i susceptible de millora. Per això s'avé més amb la concepció pragmatista de la filosofia, com hem provat de demostrar en aquest primer apartat. El model d'experiència social anhelat per Mead segueix el principi enunciat el 1896: "Hi ha tres tipus generals d'activitat humana: el treball, el joc i les arts" (Deegan, 1999, p. 33). Penso que aquest tres tipus d'activitat estan intrínsecament connectats entre sí, com es veurà quan parlem de la crítica social pragmatista. El joc constitueix el principal camp d'experimentació amb la pròpia conducta i amb la pròpia subjectivitat. Podríem dir que l'espai de joc és com un laboratori per la democràcia perquè els nens adquireixen els hàbits de conducta $\mathrm{i}$ són introduïts en pràctiques de cooperació social principalment a través del joc. Només a partir del joc, dirà Mead, serà possible que esdevinguem agents socials.

\section{El joc en la psicologia social de Mead}

Mary Jo Deegan, estudiosa de l'obra de Mead i editora del volum Play, School and Society lamenta el fet que els conceptes de "game" i "play" han tingut tan poc ressò en la literatura especialitzada, tot i jugar un paper crucial en l'obra de Mead. Deegan apunta a la qüestió de gènere ja que el joc ha estat considerat tradicionalment "feina de dones" per 
part dels sociòlegs (Deegan, 1999, p. lii). La seva reflexió demostra que el joc va ser precisament una tasca de les més importants contemplada en el treball social de Mead i els altres pragmatistes de Chicago. Ara ens toca a nosaltres recuperar els conceptes de Mead i examinar-ne les implicacions socials i polítiques.

Els conceptes de "game" $i$ "play" estan estretament relacionats amb el concepte sociològic de rol (Arditi, 1992). Des d'una perspectiva funcionalista, que és la perspectiva escollida per Mead, qualsevol ordre social pot ser entès com una distribució extensa de rols o funcions socials. Un individu és capaç d'adoptar un rol o altre depenent de la seva posició en la societat, i aquesta posició se suposa que ens diu alguna cosa sobre la identitat de l'individu. La capacitat d'adoptar rols (role-taking) és, per tant, una capacitat essencial a l'hora d'esdevenir un subjecte social (self). Cada rol està lligat a una determinada perspectiva en el sí d'institucions socials: un rol, com en el joc, obliga i prohibeix un nombre predeterminat de moviments. Aquí caldria dir alguna cosa també sobre la perspectiva funcionalista que els pragmatistes fan servir. Sovint passa que el funcionalisme es considera una mena de visió mecànica i determinista de la societat. Però tal i com l'entenen elles, el funcionalisme basat en la capacitat d'adoptar roles és una mena de ficció, una metàfora útil per representar una realitat social força més complexa. És clar que qualsevol societat és molt més complicada i misteriosa que un nombre simplificat de rols o funcions social; els agents socials són quelcom més que els rols que són capaços d'adoptar en contextos socials definits a priori. Els rols són una abstracció per dibuixar modes d'interacció social que estan donant-se en una societat a diferents temps i nivells. En aquest sentit diem que és més un organisme viu que una màquina. Per dir-ho en altres paraules: aquest model no exclou ni la novetat ni la sorpresa, simplement intenta emmarcar la novetat o la sorpresa dins un context (finit) de propòsits humans.

La capacitat d'adoptar rols és un signe de maduresa de les criatures naturals, això és, que per adquirir maduresa el nombre de rols que podem adoptar ha d'anar creixent i diversificant-se de manera que acabin esdevenint quelcom més o menys connatural a la nostra persona. La capacitat d'adoptar rols s'adquireix durant la infància i a través del joc, per tant, el joc té un rol central a l'hora d'adquirir consciència de nosaltres mateixos. Mead distingeix dues fases que es corresponen 
respectivament als termes play i game. Play (o "pure play") és el que l'infant aprèn primer abans de passar a l'estadi del joc organitzat (organized game). Play és igual a play at being something, és a dir, jugar a ser alguna cosa: "l'infant juga a ser mama, professora, policia, això és, a adoptar diferents rols" (Mead, 1967, p. 55). En aquest primer estadi, l'infant pot assimilar un nombre limitat de respostes i s'identifica només temporalment amb una organització molt simple d'estímuls i respostes. Mead anomena aquestes estructures simples d'estímulresposta la "conversa de gestos" (conversation of gestures) ${ }^{13}$. En aquest estadi, l'infant només ha après a respondre a cada acció amb una reacció, però encara no pot ser conscient del fet que les seves accions tenen un sentit social o moral ${ }^{14}$. El procés global d'aprenentatge de rols no es completa fins que l'infant és capaç d'entendre simultàniament la resposta dels altres. Aquesta situació és la de l'organized game, per la qual: "[l'infant] ha de poder prendre l'actitud de qualsevol altre implicat en el joc i saber que aquests diferents rols han de tenir una relació definida entre ells" (Mead, 1967, p. 151).

Per tal d'entendre la situació del joc organitzat ens pot ser útil seguir a Mead i utilitzar l'exemple d'esports com el baseball (Mead, 1967, p. $154)^{15}$. El que trobo especialment interessant, però, és que Mead parla del joc primari (play) principalment en termes de joc d'imitació (el que es coneix en la literatura com a pretend-play) ${ }^{16}$. Aquí podria elevar-se la pregunta de quina relació guarda l'habilitat de prendre rols d'un altre $\mathrm{i}$ l'autenticitat requerida per esdevenir una personalitat plena. És a dir, qui sóc jo al final de tot? On es troba la meva autèntica personalitat? No sóc més que una suma arbitrària de rols en un moment donat? Sóc quelcom que està més enllà dels rols que duc a terme? O només em defineixo pel rol que sóc capaç de realitzar en aquest precís moment? Què diuen aquests rols de la societat en la que visc? A tot això, Mead apunta crípticament que:

L'organització del subjecte és simplement l'organització per part de l'organisme individual del conjunt d'actituds envers el seu entorn social que és capaç d'adoptar; i les actituds envers ell des del punt de vista d'aquest entorn, o, com a element funcional en el procés d'experiència social i comportament que constitueix aquest entorn (Mead, 1967, p. 91) 
Aquí hi veiem dues coses: que el subjecte és una forma d'organització que inclou no només la meva actitud cap als altres (l'individu actuant com a jo, com a subjecte), sinó també la comprensió recíproca de les actituds dels altres envers ell (el subjecte que es percep com a objecte directe de l'acció d'altres). El que Mead sembla voler dir en aquest punt és que el subjecte individual d'alguna manera actua com un doble mirall del conjunt de rols socials presents en la seva societat. El subjecte consisteix en una organització concreta i individualitzada d'aquests rols i aquesta organització és la presentació del seu jo en societat (Goffman, 1959). El subjecte (self) és alhora tots aquests rols posats junts i quelcom que sembla estar per sota o per sobre d'aquests rols. El problema de la subjectivitat és un problema filosòfic de primer ordre. Per descomptat que l'infant encara no pot reflexionar críticament sobre aquest salt qualitatiu entre rols i autèntica personalitat. Però jugant a ser una altra cosa aprèn en general que hi ha patrons conducta que poden ser adoptats i abandonats depenent de la constel-lació social en què es trobi. L'infant aprèn gradualment que la seva conducta és la forma com els altres el veuen. Al nivell del joc primari: “[...] el subjecte que està creixent té tanta realitat o tan poca com els rols que juga l'infant" (Mead, 1967, p. 370). El món real i el món imaginari es mesclen i originen una tercera realitat, un autèntic món de ficció en la vivència de l'infant sense que això esdevingui problemàtic o angoixant. En aquest estadi, el nen o nena es refereix sovint a sí mateix en tercera persona. Quan arriba al nivell del joc organitzat, l'infant comença a entendre com se suposa que s'ha de sentir en tal posició o tal altra en primera persona ${ }^{17}$. Jugant aprenem a posar-nos en la pell de l'altre, per dir-ho en llenguatge col·loquial. I hi ha potencialment un número molt elevat de posicions dins qualsevol comunitat donada. I és clar que sempre tenim l'opció de crear-ne de nous inventant nous jocs, sempre i quan els altres s'avinguin a participar-hi. Els límits comunals són negociables i susceptibles a la persuasió.

Fins aquí hem pogut veure que la teoria del desenvolupament moral de la personalitat de Mead és formalista, basat en la capacitat de canviar les posicions dins un conjunt d'actors interactuant entre sí i aquesta capacitat és en el seu primer estadi de desenvolupament merament cognitiva. Seguint a Mead, l'infant haurà adquirit prou hàbits a partir del joc quan hagi completat tot el cercle del seu món social. Entendre el joc 
organitzat, que és una representació a escala del món adult (Mead, 1967, p. 159-160) és una pre-condició per al subjecte i per la reconstrucció social que li serà demandada quan sigui reconegut com a membre adult de la societat.

\section{Joc, treball i art com a pedres angulars de l'experiència social}

Com es relaciona l'espai de joc amb els fins de la democràcia? És l'espai de joc un context d'experimentació amb la creativitat individual i el lloc on es detecten les disfuncions de la comunitat? ${ }^{18}$ Els pragmatistes afirmen que l'espai de joc ha de tenir un lloc adequat en el sí d'una democràcia. Què significa aquesta afirmació? En primer lloc, que tots els infants mereixen un lloc on jugar. Aquesta afirmació s'ha d'entendre en el context educatiu en què sorgeix la filosofia pragmatista: els suburbis de la Chicago industrial amb altes quotes d'immigració, vagues de treballadors $i$ una alta conflictivitat social. Una de les principals tasques de la Hull House va ser treure els nens de les fàbriques i tornarlos a les escoles i als parcs (Hamington, 2009). Això no ha passat només al Chicago de principis de segle, ja que continua passant en molts països i segueix sent part important de la demanda de l'article 31 de la ONU sobre els drets de la infància. En un segon nivell de reflexió i més enllà de la rellevància històrica de la defensa dels drets de l'infant per part dels pragmatistes, penso que la importància del concepte pragmatista de joc és que permet ser vinculat a les altres formes d'activitat humana: el treball i les arts. En la visió utòpica de la societat de Mead, aquestes tres activitats es corresponen a una forma d'organització social en què els interessos de tots els membres de la societat són tinguts en consideració. Mead identifica l'artista amb el crític social, per tant, és indispensable per a l'expansió dels nostres horitzons. Per tal d'entendre això, farem referència en trets generals a aquesta visió utòpica pragmatista de la societat. James la va anomenar "república ètica"; Mead, parla "de l'altre generalitzat"; Peirce, per la seva banda, anhela una "societat d'investigadors"; Dewey marca el pas d'una Gran Societat a una Gran Comunitat. Si posem tots aquests ideals utòpics junts en resulta una societat d'individus reflexius i compromesos que treballen per enfortir els llaços comunitaris d'una banda i per ampliar els límits de les seves comunitats tot fent-les més sensibles a la diversitat humana. Provaré de 
mostrar-ho a partir de les darreres notes de Mind, Self and Society de Mead.

És un fet reconegut que les societats modernes estan esdevenint cada cop més complexes i abstractes, de manera que el significat de la ciutadania cada cop és més i més diluilt. Els actors socials es troben complicats en diverses xarxes de rols, cadascuna de les quals està alhora lligada a determinades expectatives, rols i deures. Aquesta intensificació de les xarxes socials és anomenada per Mead un "ideal de societat altament avançada" (Mead, 1967, p. 307). La situació del subjecte modern és cada cop més semblant a la d'un joc d'alta dificultat. Però en el joc social l'element lúdic és absent: les regles tenen conseqüències cada cop més confoses i menys calculables, els agents socials es troben cada cop més escindits entre responsabilitats en concurrència directa les unes amb les altres. És per això que fins i tot l'analogia entre la societat i el joc té un límit.

Mead detecta aquesta complicació exponencial de l'agència social i prova d'oferir una sortida optimista. La seva visió de la societat és funcionalista, però alhora dinàmica i orgànica. Mead parla d'una interdependència entre el nivell d'organització i unitat del grup social i el corresponent nivell d'organització i unitat interna dels individus (Mead, 1967, p. 144), tot i que fa d'una forma indirecta. Què implica aquesta interdependència entre el subjecte social i el grup al que pertany, segons Mead? Primer, considerant que cap grup social és un grup sense fissures, podríem extreure'n la conseqüència que el subjecte social està implicat tant en processos que impliquen cooperació i reforcen la cohesió social com en d'altres processos que resulten de la competència i el conflicte entre membres del grup social. Segon, que la realització de cada subjecte depèn del reconeixement dels altres i aquest reconeixement dependrà alhora del conjunt de respostes que cada societat està preparada per assumir. Tercer, que hi un moviment recíproc entre autocrítica individual i crítica social (Mead 1967, p. 255), de manera que en el procés d'intercanvi conversacional permanent entre subjecte i societat, el subjecte no només té el dret, sinó també el "deure de parlar a la comunitat de la que és part i influir en els canvis que tenen lloc en les interaccions entre individus" (Mead, 1967, p. 168).

Quines són les conseqüències de la visió de la societat de Mead? En la meva opinió, la principal virtut d'aquesta concepció medeana és que 
es basa en un intent d'equilibrar la responsabilitat individual amb la responsabilitat comunitària. D'una banda, la societat sencera és responsable dels actes dels seus membres i ha de tenir cura de tots aquells que siguin menys capaços o necessitin especial protecció. D’una altra, els individus no són mai subjectes passius sense la possibilitat d'expressar-se, sinó que les seves accions i omissions estan tenint tàcitament conseqüències per a tots els altres. La concepció de Mead prova de situar l'acció social d'una manera que sigui realista però mai resignada. És cert que els patrons de comportament que podem aprendre estan limitats pel context social, però això no és determinisme social sempre que nosaltres provem d'introduir canvis a partir de la nostra acció individual. Ara bé, l'èxit de tota novetat social dependrà sempre d'una conjuntura que li sigui favorable, i en aquesta conjuntura hi intervenen la història $\mathrm{i}$ els límits de la comunitat $\mathrm{i}$ també, perquè no dirho, l'atzar i la sort. El fer-nos reflexius sobre els rols, les actituds envers els altres i les conseqüències esperables de les accions, diu Mead, ens trobem reconstruint constantment la nostra societat més immediata (Mead, 1967, p. 386). La tasca de reconstrucció requereix creativitat i imaginació, això és, la capacitat de jugar mentalment amb diverses possibilitats per poder enriquir i ampliar el nostre imaginari social. Per dir-ho d'una altra manera: per actuar dins la societat, per treballar per ella caldrà desenvolupar la imaginació necessària per poder-nos moure entre diferents rols, els rols que hem après tot jugant. Dewey anomenava l'adquisició d'aquesta competència plasticitat (Dewey, 1966). Aquí, el tercer tipus d'activitat humana, l'art, reclama la seva funció social. Aquesta funció social era una reivindicació clàssica del pragmatisme, sobretot defensada per Jane Addams, qui deia que: "les arts (...) són precisament allò que encarna els fins últims de la Hull House" (Addams, 1960, p. 185). És a dir, la crítica de la societat industrial a través dels mitjans disponibles d'expressió individual i acció col·lectiva.

Amb aquestes notes hem introduït també una petita indicació de com revaluar les relacions entre joc, treball i art. El joc és un element necessari per tal de desenvolupar les habilitats cognitives i les virtuts morals que ens permeten interactuar amb altres. Però l'element lúdic no ha de ser del tot abandonat quan entrem en el món adult ja que contribueix essencialment al desenvolupament de l'imaginari social. La imaginació és una facultat individual que alhora és condició necessària 
per tal d'expandir i diversificar els patrons heretats de conducta. Pels adults, el joc ha de ser quelcom més que la mera recreació o l'exempció del treball (Dewey, 1966, p. 285). El treball ha de retenir quelcom de l'actitud lúdica; en cas contrari, l'activitat laboral es realitza merament pels seus resultats econòmics i deixa d'estar connectada amb una vida digna. Per això els pragmatistes defensen que les nostres societats han de tenir cura de proporcionar unes condicions laborals que deixin un marge suficient a la plasticitat i a la llibertat per tal de donar "els estímuls adequats a l'emoció i a la imaginació" (Dewey 1966, p. 205). El treball mecànic i alienant no pot proporcionar aquest estímuls. La manca de treball, sigui quin sigui, segurament tampoc.

Un altre factor important per estimular la imaginació i les emocions ve donat pel gaudi de les belles arts. És per això que les arts han de fer part dels currícula de les escoles:

la criatura encara no madura no ha de dedicar-se només al treball monòton perquè la societat estaria perdent quelcom massa valuós en acabar de forma prematura amb aquella varietat i promesa i esclat de vida que són la possessió exclusiva de la joventut i la base de l'art. (Addams, 1930, p. 358)

Dewey insisteix sovint sobre la desastrosa compartimentació entre activitats que suposa distingir entre utilitat i cultura (Dewey, 1966, p. 260). El pes de la utilitat dignifica exclusivament el treball amb valor econòmic i material mentre trivialitza les "activitats improductives" com el joc i l'art. La conseqüència inevitable és la reducció i empobriment de la nostra experiència social i comunal.

És per aquest raó que els pragmatistes postulen la continuïtat entre les diverses formes d'experiència i reivindiquen l'eliminació de divisions artificials $i$ estèrils. Joc, treball $i$ art poden correspondre a categories relatives a pràctiques socials ben definides en quant al mode de la seva execució. Però elements lúdics, estètics i productius es troben en major o menor mesura en les nostres pràctiques socials, acomplint diverses funcions en l'execució mateixa de la pràctica. Pensem, per exemple, en el professor de piano. Només amb certa disciplina de treball haurà pogut assolir cert grau d'excel·lència necessari per exercir la seva professió, però aquesta excel·lència ha fet menester el gaudi en l'exercitació de la 
música com a activitat plenament estètica, fent que la disciplina hagi resultat ser-li tan natural com un joc, aprenent-ne els límits, negociant amb gosadia amb els cànons. El professor de piano que no sàpiga transmetre aquesta harmònica combinació d'elements lúdics, disciplinaris i estètics segurament no serà un bon professor de piano.

En aquesta compartimentació "fluida" d'activitats, mantenim que el joc és la forma més bàsica de praxis humana. Hans-Georg Gadamer (1999) ha explicat a finals del segle XX que l'experiència estètica és un tipus molt especial de joc de les facultats cognoscitives, seguint l'estela de la Crítica del judici (1790) de Kant les Cartes sobre l'educació estètica (1795) de Schiller. Tornem a tancar el cercle sobre el joc després d'haver-lo desplegat sobre el treball i les arts. Desgraciadament, els pragmatismes clàssics no van poder conèixer el moviment de l'hermenèutica filosòfica iniciat per Gadamer, però penso que una síntesi entre ambdós seria un diàleg fructífer a partir del encara poc estudiat The Philosophy of the Present (1932) de Mead. Però això ja és una altra història.

Ara per ara hauríem de retenir que el fi últim de la filosofia social pragmatista és la creació d'una experiència social genuïnament democràtica. Per Mead, com per Addams, proporcionar les condicions d'aquest tipus específic d'experiència requereix un canvi de perspectiva:

Sempre és fàcil per una democràcia que insisteix en dictar els seus propis programes excloure la imaginació, desconfiar del sentiment i empetitir l'espai de recreació. Cal quelcom com una fe unida i energia col·lectiva per insistir en el fet que els grans regals fets a la humanitat haurien de trobar la forma d'expressió que es desenvolupa en les arts. (Addams, 1960, p. 185)

En resum, la pintura final de la societat pragmatista té una doble estructura. D'una banda, una societat que demanda als individus que cultivin virtuts cíviques, això és, hàbits que afavoreixen la vida comunitària. L'adquisició d'aquests hàbits està condicionada per les primeres fases del joc infantil i va progressant en tota mena de jocs organitzats pels quals adquirim patrons de conducta que es van consolidant de forma natural i ens orienten en el futur. D'altra banda, l'individu ha de reconèixer els interessos de tots els implicats en la tasca 
de reconstrucció social. Mead anomena aquesta referència als interessos de tots "imperatiu categòric" (Mead 1967, p. 386), que és un imperatiu que reclama el més ampli univers de discurs. Penso que just aquest punt pot ser interessant pel nostre món globalitzat. Veig en el pragmatisme de Chicago dos tipus diferents de moviments. El primer és un esforç per acomodar diferències individuals tot ampliant la imaginació social i política de la comunitat, de manera que pugui prevaldre la natural constitució pluralista de les nostres societats. En aquest moviment cal fer molta feina a nivell del joc i del cultiu de les arts, que són les que s'ocupen d'exercitar el coneixement empàtic de l'altre i el salt qualitatiu que cal per anar més enllà de la mera facticitat. L'altre moviment reclama un mínim de justícia social de manera que tots els individus puguin tenir les mateixes oportunitats de desenvolupar els seus interessos particulars. En aquest moviment és indispensable una regulació del treball assalariat compatible amb l'expressió més àmplia possible d'interessos humans (compatibles amb la democràcia, però aquest parèntesi segur que també el podríem discutir). Finalment, aquests dos moviments de dins cap a fora i de fora cap endins estarien travessats per un tercer moviment transversal que empenyeria per tal de fer els límits comunitaris més laxes i fer les comunitats més inclusives. Només una societat amb un mínim de justícia social ${ }^{19}$, això és, una societat no oprimida per la tirania política o per la tirania de les condicions laborals pot promoure activament l'expansió dels horitzons comunitaris a través de l'exercici lliure de la imaginació política.

Es diu que la filosofia de Mead és ingènua pel que fa a les possibilitats reals de la creativitat humana. Però Mead no està pensant en una societat que no deixi prou lloc als errors i les faltes. Però, com Mead diu: "els errors no són pecats" (Mead 1967, p. 389). I podríem afegir aquí: hi ha maneres de millorar l'ordre social en general, però aquestes solucions tampoc són miracles. Requereixen compromís i l'acció co-responsable d'individus i comunitats.

\section{Conclusions i tasques pendents}

M'agradaria resumir fins aquí el que considero que han estat les aportacions més interessants de la filosofia pragmatista clàssica en general, i de Mead en particular: 
(1) Es recupera el significat central i antropològic del joc. El joc és un concepte nuclear de la psicologia social, no només pel desenvolupament infantil, sinó també pel seu lloc dins el sí de la vida humana. Els espais de joc actuen com a laboratoris d'experiència social: refermen els mecanismes de control social, però també ens permeten detectar les disfuncions de l'ordre social i tornar críticament sobre elles.

(2) El joc es posa en connexió amb els altres dos tipus fonamentals d'activitats humanes: el treball i les arts. Només la conjunció harmònica dins la societat d'aquest tipus d'activitats, fugint de la priorització excessiva de les unes sobre les altres, ens proporcionarà les condicions necessàries per enriquir els modes heretats d'experiència social.

(3) Donada la postulada continuïtat entre individu i comunitat, escola i entorn laboral, les formes socials i polítiques d'associació, es proposa aquí un model de co-responsabilitat. D'una banda, els individus han de ser reflexius $i$ oberts al perfeccionament de pràctiques cooperatives $i$ assumir la responsabilitat sobre el seu entorn. D'altra banda, l'entorn social ha de prendre consciència que sempre serà tan dèbil com el més vulnerable dels seus membres ${ }^{20}$. Però la co-responsabilitat només serà possible si l'estructura bàsica de la societat ofereix un mínim d'igualtat formal a nivell de drets socials $\mathrm{i}$ econòmics $\mathrm{i}$ és capaç de reconèixer la pluralitat intrínseca de les formes de vida dins la comunitat. Per tant, la visió pragmatista de la societat és un intent de donar cabuda alhora a les demandes de la universalitat dels drets $\mathrm{i}$ al reconeixement de la diversitat humana ${ }^{21}$.

Espero amb això haver presentat d'una forma prou atractiva i entenedora la filosofia social pragmatista. Aquesta filosofia es compromet amb una forma de progrés social que reivindica no només el perfeccionament dels mitjans, sinó també dels fins. Per perfeccionar els mitjans només ens calen avenços tècnics. El pragmatisme, però, pensa que el progrés suposa "enriquir els propòsits existents i formar-ne de nous" (Dewey 1966: 223). El progrés social és un treball constant d'expansió d'horitzons i d'ampliació de cercles, una feina constant sobre l'experiència social comuna. El progrés no és lineal i endavant, com pensaven els positivistes, sinó "lateral" com proposa Jane Addams, a partir del "coneixement empàtic" (Hamington, 2009). Només en aquest sentit podrem parlar d'una societat democràtica progressiva amb les paraules de Dewey, una societat que "compta les variacions 
individuals com un bé preciós ja que troba en elles els mitjans per al seu propi creixement. Per això, una societat democràtica, per ser consistent amb el seu ideal, haurà de permetre la llibertat intel·lectual i el joc entre diversos interessos i talents en les seves mesures educatives" (Dewey, 1966, p. 305).

La filosofia social pragmatista ha estat aquí exposada com una proposta atractiva a l'hora de reflexionar sobre el paper del joc, el treball i les arts en la societat democràtica, però no podem considerar-la encara autosuficient ni acceptar-la acríticament, doncs això aniria en contra del seu propi esperit. Els pragmatistes van dedicar molta energia a reivindicar l'espai de joc d'acord amb l'incipient playground movement (Hamington, 2009) i a denunciar les disfuncions socials causades per l'avenç feroç d'un capitalisme sense rostre humà. La seva visió de l'art més enllà de l'escola i la vida comunitària, l'art de museu $\mathrm{i}$ de crítica refinada els semblava una aberració. Art as Experience de Dewey és un intent força críptic i encara poc estudiat que no escapa a ambigüitats i segurament caldria actualizar-lo. Recuperar-lo en les seves línies més inspiradores, si s'escau, és una tasca que avui, amb pesar, encara tenim pendent.

\section{Notes}

1 Ian Bogost, reconegut dissenyador de jocs i especialista en comunicació, s'hi ha pronunciat força críticament. Vegi's adreça web a les referències bibliogràfiques.

2 Al nostre terme "joc" li corresponen els respectius "game" and "play" anglesos. Els termes no se solapen exactament i com ha mostrat Huizinga (2007) abastament, cal ser curosos amb els camps semàntics dels fenòmens lúdics en les diverses famílies lingüístiques, perquè algunes associacions poden arribar a resultats sorprenents. Per aquest motiu, seguirem usant "game" i "play" al llarg de tot l'article. Però la principal raó és la distinció sistemàtica que en fa Mead, identificant els termes amb diferents etapes del desenvolupament de la personalitat de l'infant.

3 També seguirem usant ocasionalment el terme "self". Aquest "self" es podria traduir com a "subjecte" o com a "personalitat", també mostra certa proximitat amb el terme psicoanalític del "jo" però sense pressuposar profunditats insondables (els pragmatistes són externalistes) ni enrevessats traumes infantils (des del pragmatisme es parlaria de "disfuncions socials"). El "self", tal i com en parla Mead i veurem més endavant, és el centre de totes les nostres disposicions conductuals envers els altres i es caracteritza per cert grau de reflexivitat.

4 Vegi's el lloc web de la Jane Addams Hull-House:

http://www.uic.edu/jaddams/hull/hull_house.html

5 Mary McDowell va estar formant mestres de kindergarten entre 1894 i 1901. Fröbel 
defensava, entre altres coses, que cada petit món ha de tenir el seu espai de jocs, ja que les activitats lúdiques nodreixen virtuts morals i cíviques (Fröbel, 1997, p. 50).

6 El pacifisme, ahir com avui, era considerat antipatriòtic, sobretot en el context que ella va viure, marcat per la Primera Guerra Mundial. Segons Deegan (1999) i Hamington (2009), el feminisme i el pacifisme d'Addams explicarien en gran part la recepció insuficient de la seva obra.

7 Els settlement de Chicago eren els suburbis poblats majoritàriament per població immigrant del camp dels Estats Units i de totes les nacionalitats del món que treballaven principalment a les fàbriques en una Chicago que es transformava a gran velocitat en un monstre industrial (Westbrook, 1991).

8 La meva tesi és que es pot parlar a grans trets de tres fornades o generacions de pragmatisme filosòfic; primer a Amèrica, però després també a Espanya, Itàlia, Alemanya $\mathrm{i}$ en altres països. La primera generació, coneguda com a "pragmatisme clàssic", es compon de l'obra de C.S. Peirce, F.C.S. Schiller, William James, John Dewey, G.H. Mead, George Santayana, Jane Addams i Giovanni Papini. La segona generació es correspondria a l'interval aproximat 1960-1980 i inclouria a W.V. Quine, Richard Rorty, Hillary Putnam, Richard Bernstein, Karl-Otto Apel, Jürgen Habermas i Nelson Goodman, entre d'altres. La tercera generació sembla ser molt més heterogènia i hi podríem comptar a Cornel West, Robert Brandom, Richard Shusterman, Charlotte Haddock Siegfried i Hans Joas. Per descomptat que aquesta divisió en generacions no té la pretensió de ser una genealogia exhaustiva del pragmatisme ni reduir la contribució teòrica dels autors esmentats al pragmatisme. El pragmatisme, com totes les grans famílies filosòfiques, presenta les seves idiosincràsies i desavinences internes. Avui dia segueix força actiu, com es pot veure en pàgines insígnia del moviment com www.pragmatism.org

9 Els articles de Peirce "The Fixation of Belief" (1877) i "How To Make Our Ideas Clear" són considerats els textos fundacionals de l'escola. William James va escriure anys després un llibre amb el títol Pragmatism. A new name for old ways of thinking (1907) que pot ser vist com una compendi general de la filosofia pragmatista respecte totes les subdisciplines filosòfiques, principalment en metafísica, ètica i filosofia política.

10 Les fonts bibliogràfiques d'aquest article es troben en tres llengües (anglès, alemany, castellà), mentre que l'exposició es fa en català. Per tal de fer el text final més uniforme i llegible he decidit traduir totes les cites al català. Fins on jo sé, no existeix cap traducció al català de les obres dels pragmatistes clàssics.

11 Aquesta doctrina s'anomena també "democràcia radical" (Bernstein, 2010). Aquesta teoria de la democràcia radical s'ha de distingir de la democràcia radical defensada per Ernesto Laclau i Chantal Mouffe, entre d'altres. La visió radical de la democràcia defensada pels pragmatistes es basa en afirmacions com aquesta, deguda a Dewey: "E1 fi de la democràcia és radical perquè no s'ha assolit encara adequadament a cap país ni a cap època" (citat per Bernstein, 2010, p. 77)

12 Es podria objectar aquí que els pragmatistes idealitzen la democràcia $\mathrm{i}$ no es preocupen de reflexionar críticament sobre els seus límits. Això és veritat pels pragmatistes ja que segons ells: “(...) la democràcia no és un alternativa a altres principis de la vida en societat. És la idea de la vida comunitària en sí mateixa" (Dewey 1984, p. 328). Espero mostrar al final d'aquest article que l'ideal democràtic requereix també una reconstrucció constant.

13 Segons Mead (1967) la "conversa de gestos" es correspon a l'estadi més rudimentari 


\section{Núria Sara Miras Boronat - Joc, Treball i Art}

de l'adquisició del llenguatge. No només els humans, també altres animals ostenten formes bàsiques de conversa de gestos. Però només els humans l'han refinat fins a una forma de conducta significativa o llenguatge.

14 Axel Honneth sosté que la primera imatge del propi jo és purament cognitiva, però que es pot transformar en pràctica quan entrem en contextos normatius (Honneth, 1994, p. 123). Això suggereix que la construcció de la personalitat ha de passar no només per diferents estadis cognitius, sinó també per diferents estadis de desenvolupament moral.

15 En el nostre context cultural, segur que ens aclareix més aquesta analogia pensar en el Barça de Messi. Altres potser trobaran més il•lustrativa l'analogia amb els escacs. També ens pot ajudar pensar els diferents rols com en els papers d'un drama amb actors interactuant de formes diverses que depenen de la seva rellevància per a l'argument o la trama de l'obra. Goffman (1959), un deixeble de Mead, fa precisament aquesta analogia d'una manera prou interessant.

16 La distinció entre game i play sembla ser molt simple, però és molt important per connectar les diverses fases de desenvolupament de la personalitat en la teoria de Mead. La meva tesi és que el joc d'imitació (pretend-play) és la millor il.lustració pel joc primari, ja que permet explicar-lo en termes d'una conversa gestual molt rudimentària, un altre concepte clau dins la psicologia naturalista de Mead. Mead també fa servir d'exemple en aquesta el cas freqüent de l'amic imaginari (Mead, 1967; Deegan, 1999), també ho fa Joas (1989). Però jo defenso que el joc d'imitació és encara una forma més bàsica $\mathrm{i}$ tot $\mathrm{i}$ que no disposo de dades empíriques, diria que l'amic imaginari no es un fenomen tan vast com la mera imitació dels rols dels grans per part dels petits. També trobo problemàtica l'equiparació de Honneth entre adopció de rols i joc primari, d'una banda, i el joc organitzat i la competició, d'un altra (Honneth, 1994, p. 124). L'assimiliació entre joc primari i l'adopció de rols planteja la pregunta de si ja hem adquirit en aquest estadi una noció de què significa adoptar un rol en general, qüestió no plantejable des de la lectura de Mead, ja que aquesta noció no s'adquireix fins a l'estadi del joc organitzat, quan assolim la perspectiva del que Mead anomena "l'altre generalitzat" (generalized other). Però assolir aquesta perspectiva tampoc significa que la meva relació amb els altres reals o potencials sigui una relació competitiva. En altres paraules: els jocs de competició només són possibles a l'estadi del joc organitzat però el joc organitzat pot presentar-se en variants no competitives (per exemple, els jocs de rol on l'objectiu no es guanyar sinó l'excel•lència en la qualitat de la performance). Mead es refereix ocasionalment a altres tipus de jocs, com per exemple, jugar amb nines com una possibilitat de jugar amb rols o el joc de fet $\mathrm{i}$ atrapar, però mai ofereix cap sistematització de les "innumerables formes de joc" (Mead, 1967, p. 364) ni respon a la pregunta de quina edat aproximada marca el pas del joc primari al joc organitzat (Joas, 1989, p. 117).

17 També la distinció entre "jo" $(I)$ i “em/mi/ a mi" (me) és fonamental per a la teoria de Mead de la personalitat però ell mai la va vincular directament amb la distinció entre game $i$ play. Per tant estic assumint que l'organització dels diferents me en un $I$ es correspon al subjecte ja madur. En altres passatges Mead postula que el joc, juntament amb el llenguatge, il.lustren les condicions socials sota les quals el subjecte es capaç de percebre's alhora com a objecte (Deegan, 1999, p. 7). Això parlaria a favor de la meva tesi. Però en un altre lloc Mead apunta que el joc organitzat "requereix un subjecte ple, mentre que pel joc primari [play, NSMB] només calen peces del subjecte" (Deegan, 1999 , p. 15). El joc és un procediment reglat proper al dispositiu complex de l'univers adult, de manera que és pensable que diferents nivells de jocs segons la seva complexitat 
puguin correspondre a diferents graus de maduresa.

18 "El joc tendeix a reproduir $\mathrm{i}$ afirmar tant les crueses com l'excel-lència de la vida adulta circumdant. L'escola ha d'ocupar-se de proporcionar un entorn en què joc i treball han de ser conduïts de manera que facilitin un creiexement mental i moral desitjable. No n'hi ha prou amb introduir només jocs i treballs manuals. Tot depèn de la manera en què aquests són emprats." (Dewey, 1966, p. 196).

19 D'acord amb Hamington (2009) aquest punt era una de les claus de l'ètica social d'Addams, per qui la democràcia havia d'establir un nivell mínim d'igualtat econòmica i social tant com la dimensió política.

20 Addams s'inspirava en aquestes línies de Carlyle: "Els hombes no poden viure aïllats, estem tots units en la misèria mútua com els nervis ho estan al mateix cos. Cap home, per elevada que sigui la seva posició, pot oblidar-se del que està molt més avall" (Pinhard, 2009, p. 52).

21 En aquest punt estic d'acord amb les principals conclusions d'Aboulafia (2001).

\section{Referencias}

Aboulafia, M. (2001). The Cosmopolitan Self. George Herbert Mead and Continental Philosophy. Urbana/Chicago: The University of Illinois Press.

Addams, J. (1930). The Second Twenty Years at Hull-House. New York: MacMillan.

Addams, J. (1960). A Centennial Reader. New York: The Macmillan Company.

Arditi, G. (1992). Role as a Cultural Concept, in P. Hamilton (ed.) George Herbert Mead: Critical Assessments, vol. III, New York: Routledge: 199-221.

Bernstein, R. (2010). The Pragmatic Turn. Cambridge, MA: Polity Press.

Bogost, I. (03.05.211). Persuasive Games. Exploitiationware. Recuperat (12.05.2013), de Gamasutra (www.gamasutra.com).

Deegan, M. J. (1999). Play, School and Society. New York/Berlin: Peter Lang.

Dewey, J. (1920). Reconstruction in Philosophy. New York: Henry Holt and Company.

Dewey, J. (1966). Democracy and Education. London: The Free Press.

Dewey, J. (1984). The Later Works, vol. 2 1925-1927. Carbondale and

Edwardsville, Southern Illinois University Press.

Dewey, J. (2005) Art as Experience. New York: Penguin.

Fink, E. (1993). La filosofia de Nietzsche. Madrid: Alianza. 
Fröbel, F. (1997). Spiel als höchste Stufe der Kindesentwicklung

(1826), in H. Scheuerl (ed.), Das Spiel, vol. 2, Basel: Beltz: 46-50.

Gadamer, H.-G. (1999). Wahrheit und Methode. Tübingen: Mohr Siebeck.

Goffman, E. (1959). The Presentation of the Self in Everyday Life. New York: Doubleday \& Company.

Hamington, M. (2009). The Social Philosophy of Jane Addams.

Urbana/Chicago: University of Illinois Press.

Honneth, A. (1994). Kampf um Anerkennung. Frankfurt am Main:

Suhrkamp.

Huizinga, J. (2007). Homo Ludens. Madrid: Alianza.

James, W. (1907). Pragmatism. A New Name For Some Old Ways of

Thinking. London: Longmans, Green \& Co.

James, W. (1987) A Pluralistic Universe, in Writings 1902-1910. New

York: The Library of America: 625-819.

Joas, H. (1989). Praktische Intersubjektivität. Frankfurt am Main:

Suhrkamp.

Mead, G. H. (1967). Mind, Self, and Society from the Standpoint of a Social Behaviorist. Chicago: The University of Chicago Press.

Pinhard, I. (2009). Jane Addams: Pragmatismus und Sozialreform.

Pädagogische Theorie und Praxis der Progressive Era. Opladen

\& Farmington Hills: Budrich UniPress,.

Runkel, G. (2003). Das Spiel in der Gesellschaft. Münster: LIT.

Russell, B. (1966). Philosophical Essays. London: George Allen \& Unwin.

Sutton-Smith, B. (2001). The Ambiguity of Play. Cambridge/London:

Harvard University Press.

Westbrook, R. B. (1991). John Dewey and American Democracy.

Ithaca/London: Cornell University Press.

Núria Sara Miras Boronat es Investigadora Postdoctoral del Seminari de Filosofia Política, Universitat de Barcelona

Contact Address: c/ Alcalde Costa 40, 1r E. 25002 Lleida. E-mail address: nuriasara@gmail.com 
Instructions for authors, subscriptions and further details:

http://brac.hipatiapress.com

\section{Apuntes sobre la Enseñanza de la Escultura en México}

Francisco Javier Tous Olagorta ${ }^{1}$

1) Escuela Nacional de Artes Plásticas / Universidad Nacional Autónoma de México. Posgrado en Artes Visuales - Departamento de Escultura - México, D.F.

Date of publication: October 3rd, 2013

To cite this article: Tous Olagorta, Fco. J. (2013). Apuntes sobre la Enseñanza de la Escultura en México. BRAC - Barcelona Research Art Creation, 1(2), 175-202. doi: 10.4471/brac.2013.08

To link this article: http://dx.doi.org/10.4471/brac.2013.08

\section{PLEASE SCROLL DOWN FOR ARTICLE}

The terms and conditions of use are related to the Open Journal System and to Creative Commons Non-Commercial and Non-Derivative License. 
BRAC - Barcelona Research Art Creation. Vol. 1 No. 2,

October 2013 pp. 175-202

\section{Notes on Teaching of Sculpture in Mexico}

Francisco Javier Tous Olagorta

Universidad Nacional Autónoma de México.

\section{Abstract}

In an informative way, here is a presentation of some notes and reflections of the course of the course of the history in the fine art of sculpture, starting from the Ancient Academy of San Carlos in Mexico, founded in 1781, which was transformed after its independence and throughout 232 years into the Escuela Nacional de Artes Plásticas, incorporated since 1910 to the Universidad Nacional of Mexic, which is now one of the most important referring in the República Mexicana and Latin America for teaching and research within the universities where are taught Visual Arts, taking into account that since August 2011 began to teach a doctorate in Arts and Design.

Keywords: teaching, university, research, sculpture

2013 Hipatia Press

ISSN 2014-8992

DOI: $10.4471 /$ brac. 2013.08 


\section{Apuntes sobre la Enseñanza de la Escultura en México}

Francisco Javier Tous Olagorta

Universidad Nacional Autónoma de México.

\section{Resumen}

Se presentan de forma sintética y a modo informativo, unos apuntes y reflexiones, sobre el desarrollo de la historia de la enseñanza de la escultura dentro de las Bellas Artes, iniciando desde la Antigua Academia de San Carlos de México fundada en 1781, que se transformó tras su Independencia y con el transcurrir de 232 años, en la actual Escuela Nacional de Artes Plásticas, incorporada desde mayo de 1910 a la Universidad Nacional de México, que es en la actualidad del siglo XXI, uno de los referentes más importantes en la República de México y Latinoamérica para la enseñanza y la investigación dentro de las universidades en donde se imparten las Artes Visuales, teniendo en cuenta que desde agosto del 2011 comenzó a impartirse un doctorado en Artes y Diseño.

Palabras claves: enseñanza, universidad, investigación, escultura 


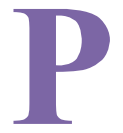

ara llevar a cabo esta investigación que abarca la enseñanza de la escultura, desde la Antigua Academia de San Carlos a la actual Escuela Nacional de Artes Plásticas, se utilizó una amplia bibliografía, revisándose diversos autores y fuentes de primera mano, que comprendieron historiadores de arte, ensayos publicados, catálogos de exposiciones, los Planes de Estudios y los Programas de trabajo de los Talleres de Escultura de las instituciones mexicanas revisadas.

También se dispuso del acervo histórico de la antigua Academia de San Carlos de México (creada en 1781). Parte de la documentación de primera mano que se revisó, se encuentra en los "Archivos sin Clasificar" y en los "Fondos Reservados del Acervo Histórico de la antigua Academia de San Carlos de México", perteneciente a la actual Escuela Nacional de Artes Plásticas (ENAP) y a la actual Facultad de Arquitectura de la Universidad Nacional Autónoma de México (UNAM).

La educación artística orientada a la escultura en México, es analizada, y revisada de modo: historicista, explicativo y descriptivo; basándose en su desarrollo y cómo fue enseñada, buscando y encontrando las razones y causas que ocasionaron los cambios del concepto escultórico.

Como método, se llevaron a cabo las revisiones de los distintos documentos, bajo una línea de investigación de tipo descriptivo, que sirvió para analizar cómo es y cómo se manifiesta un fenómeno y sus componentes, permitiendo detallar cada uno de los puntos estudiados básicamente a través de la medición de uno o más de sus atributos; además de ser también explicativa para buscar y encontrar las razones o causas que ocasionan ciertos fenómenos, siendo su objetivo último explicar por qué ocurre un fenómeno y en qué condiciones se da éste. ${ }^{1}$

\section{Antecedentes académicos}

En los inicios de la Real Academia de las tres Bellas Artes de San Carlos en la Nueva España, se contrataron diversos maestros españoles formados en el academicismo europeo, siendo el primer escultor y arquitecto de importancia el valenciano don Manuel Tolsá ${ }^{2}$, quien fue 
nombrado Director de la Rama de Escultura a partir de 1791.

Este escultor, desempeñó eficazmente su labor al modo de las Academias europeas; esto consistía en que el alumno aprendía en un principio los Fundamentos del Dibujo y a partir de ello pasaba a copiar partes del cuerpo humano presentadas en láminas, más adelante continuaba con la cabeza completa, brazos, piernas, el torso y finalmente terminaba con el dibujo del cuerpo completo a partir de modelos determinados; existía para ello un repertorio de estampas y grabados de "buenos maestros" que servían como estereotipos del cuerpo humano.

Una vez que se dominaba el dibujo de copia de láminas, el estudiante pasaba a lo que se conocía como Sala de Yesos, donde se copiaba de esculturas que las academias tenían como modelos de belleza clásica. Los yesos eran partes de figuras humanas, también cuerpos completos vestidos o desnudos, grupos escultóricos, etc. y comprendían una gran diversidad de estatuaria griega, romana, renacentista y neoclásica; entre ellos había figuras de bulto redondo y relieves; también animales, ornamentación y objetos arquitectónicos como capiteles.

Los yesos, de los que la Antigua Academia de San Carlos de México llegó a tener la mejor y más completa colección de América, se convirtieron durante casi doscientos años en el material docente por excelencia para la enseñanza del arte.

El fin del aprendizaje era que el alumno aprendiera las partes del cuerpo humano y del todo de un modo progresivo, así como la simetría, la proporción, el modelado en arcilla y el dibujo de las figuras tridimensionales junto con el sombreado de volúmenes de los que tomaría conocimiento de "la belleza" clásica.

Por último, dentro de su aprendizaje académico, el alumno pasaba a la Sala del Natural, donde se enfrentaba al modelo, desnudo o vestido, en las que el profesor instruía al alumno sobre "la Expresión y la belleza de las formas... También estudiaría óptica y el efecto de los paños en el maniquí" 3.

Esta práctica metódica generaba sobre todo expertos dibujantes, que representaban principalmente el cuerpo humano; la creación libre no estaba bien vista en la Academia, ya que la institución promovía en la práctica, la formación estricta y moralizadora, sujeta a reglas sin 
independencia y ateniéndose a las fórmulas académicas que se imponían.

Otros estudios importantes que se incorporaron a la enseñanza de las Bellas Artes y por lo mismo a la Escultura, fueron la Geometría, la Perspectiva y las Matemáticas y con el tiempo, las academias incluyeron la Historia del Arte, la Composición y la Anatomía artística, que entre sus objetivos comprendía: la osteología, la miología, la artrología, la morfología y el estudio de las facciones y expresiones de la cara.

Por lo tanto, las tres etapas generales del aprendizaje académico que perduraron prácticamente hasta los primeros años del siglo XX, se resumen en: la copia de dibujos bidimensionales, la copia de yesos y la copia del natural. Las Academias se reservaban el papel de impartir las enseñanzas teóricas y el dibujo con modelo desnudo, lo cual era obligatorio.

Esta formación era prácticamente la misma para todos, diferenciándose los que se especializaban en la Escultura, con la práctica del modelado, tanto en relieve como en bulto redondo, ya que la profesionalización especializada en procedimientos específicos, como la talla en mármol o la fundición a la cera perdida, generalmente se aprendía en talleres externos independientes, a los que no era fácil ingresar como aprendiz, además de que eran regidos directamente por el estilo personal de los maestros.

\section{La Academia de San Carlos tras la Independencia}

En México, tras la Independencia iniciada en 1810 y consumada en 1820, la Academia de Bellas Artes de San Carlos pasó por un periodo decadente, resurgiendo hacia mediados del siglo XIX, con la contratación de artistas extranjeros de formación académica. Fue el escultor español, Manuel Vilar (Barcelona 1812 - México 1860), quien quedó contratado para dirigir la rama de Escultura, el que se encargó de la renovación; este explicaba en un manuscrito fechado el 9 de mayo de 1852, a la Junta Directiva de la Academia Nacional de San Carlos, el siguiente método:

“...para hacer el estudio de la escultura comienzan los discípulos por 
copiar en barro y de todo relieves las obras antiguas, a saber: $1^{\circ}$ pies y manos, $2^{\circ}$ cabezas, $3^{\circ}$ torsos, $4^{\circ}$ figuras. ${ }^{\prime 4}$

A él, influido por un cierto romanticismo, se le debió la introducción en México de la talla en mármol y los estudios de composición. Junto a un academicismo afrancesado que dominaba a la mayor parte de los artistas de finales del S. XIX, se fue dando un arte nacionalista, que serviría al estado para ir forjando las características propias: en la escultura se vería reflejado en la representación de héroes y personajes históricos que se convirtieron en símbolos de identidad.

Los discípulos de Vilar que continuaron tras su muerte, como profesores de escultura de tradición académica fueron Epitacio Calvo (1832-1895), Felipe Sojo y el Miguel Noreña (1843-1894), este último creador de la notable estatua del Monumento a Cuauhtémoc en 1887, que se encuentra emplazada en el cruce de la avenida de los Insurgentes con la avenida de la Reforma, en el Distrito Federal.

\section{Anti-academicismo revolucionario}

Con el paso al siglo XX y el transcurrir de la Revolución Mexicana a partir de 1913, aparecieron en la capital del país las primeras "Escuelas de Arte al Aire Libre". Con ellas ocurrieron algunos hechos de importancia en la formación de los artistas mexicanos, ya que se reafirmaron en el arte nacionalista más auténtico, mostrando en general su inconformidad con los métodos de enseñanza académicos tradicionales, que no aceptaban las nuevas corrientes plásticas que estaban dándose en Europa. Por ello, de un método tradicional académico, se pasó a otro más innovador, con talleres libres, en donde se valoraba más la espontaneidad y la expresión del individuo, aunque se desarrollaron sin una metodología propia de la enseñanza y así fue que estas escuelas terminaron por perder su impulso inicial $\mathrm{y}$ prácticamente desaparecieron a los pocos años.

De ellas destacaremos la fundación en 1927, de la "Escuela Libre de Escultura y Talla Directa". Ésta, se instaló en la Ciudad de México, en el ex convento de la Merced, bajo la dirección del escultor Guillermo Ruiz; ahí se abrieron talleres de Talla directa en Piedra y Madera, así 
como un Taller de Metal.

La obra escultórica antiacadémica y nacionalista realizada durante este periodo y durante los siguientes años a modo de arte oficial, por un grupo de diez escultores, será conocida por la crítica, tras una exposición de obras de pequeño formato en el Palacio de Bellas Artes en el DF, en 1990, como la "Escuela mexicana de escultura".

\section{La incorporación a la Universidad Nacional de México}

Los primeros Planes de Estudios y programas de asignaturas modernos, que se realizaron en la "Escuela Central de Artes Plásticas", como fue llamada durante unos pocos años la antigua Academia de San Carlos, datan de 1930, y se dieron tras su integración en la Universidad Nacional de México, que había alcanzado la autonomía universitaria en 1929.

En los archivos sin clasificar de la Academia de San Carlos, se encuentran 17 programas de Escultura y oficios relacionados, destacando los siguientes seis: "Programa para Clase de Modelado y Fundición", del profesor Ignacio Asúnsolo; "Programa de Talla directa en Madera" del profesor Guillermo Toussaint; "Programa de Escultura en Piedra" del profesor Guillermo Ruiz; "Programa de Anatomía (Mecánica humana)" del profesor Carlos Dublan; "Programa de Ebanistería" del profesor Arnulfo Velasco; "Programa de Ornamentación Arquitectónica" del Profesor Federico Canessi del Campillo y el "Programa de Orfebrería" del profesor García Cahero.

De estos programas de Escultura, los de Talla directa en Madera y en Piedra fueron los más innovadores del momento, al romper con la rígida disciplina académica.

Desde entonces, el Plan de Estudios General de 1930, contó con una exposición de motivos principales, que lo estructura en base a conseguir la especialización técnica y práctica del alumno, inculcándole un compromiso social con su trabajo. En los Programas particulares de los años 30 no se indicaban objetivos principales, ni como se evaluaba, eran simplemente unas hojas con el nombre de las materias, en donde se describía un temario con diversos puntos, en donde el conocimiento de los materiales y los principios generales de la escultura eran marcados 
como temas. También se indicaban diferentes cuestiones para estudiar, como el arte autóctono y se realizaban maquetas a escalas como parte del proceso.

Por ejemplo, el de "Talla directa en Madera" del profesor Guillermo Toussaint, firmado el 31 de mayo de 1930, marcaba los ejercicios a realizar con diferentes herramientas:

"Ejercicio de corte con sardina o serrote, en varias direcciones, en madera desflemada y en troncos de árbol, para conocer las calidades de las diversas maderas que pueden usarse (...), Desbaste: Ejercicios practicados con hacha, hachuela, etc." 5

Estos ejercicios contemplaban la realización de esculturas en bulto y de relieves, con temas como naturalezas muertas, paisajes, retratos, máscaras, etc.; en el programa se indica que el profesor tomará en cuenta la capacidad de cada alumno.

\section{La Escuela Nacional de Artes Plásticas}

Entre 1935 y 1936, la Antigua Academia de San Carlos tomó su nombre definitivo como Escuela Nacional de Artes Plásticas (ENAP), y se presentó un proyecto para la Carrera de Escultor desarrollada en cuatro años y que contenía para el primer año, temas como la preparación de las herramientas, ejercicios de volumen en Modelado con y sin modelos vivo, el manejo del yeso en Moldes y Vaciados, el aprendizaje del oficio de cantero, la Anatomía Artística, el Dibujo del Natural, el Constructivo y la Perspectiva.

Para el segundo año, además de los Dibujos, se modelaban cabezas y bustos en bulto redondo y en relieves, continuándose con la copia en materiales definitivos. En el tercer año se desarrollaban en modelado figuras vestidas y desnudas, en bulto redondo y en relieves, con y sin modelo vivo, siendo importante la construcción de armazones de hierro para estructurar el modelado; también se realizaban estudios de composiciones ornamentales y maquetas, así como la Talla Directa en distintos materiales a elección del alumno, se incluía un primer curso 
anual de Historia del Arte. Por último en el cuarto año, se desarrollaban composiciones de Escultura modelada y se ejecutaban algunos trabajos en materiales definitivos, incluyéndose un segundo año de Historia del Arte.

En 1959 bajo la dirección del Mtro. Roberto Garibay en la ENAP, se hicieron reformas a los Planes de Estudio; en ellos, como finalidad para la Escultura, se estableció una mayor capacitación técnica dirigida a los distintos problemas específicos del área, como son el retrato, la proyección y la composición escultórica; dejando para el último año la ejecución de trabajos con tema dado y con fines de aplicación profesional.

Las asignaturas de 1959 para la carrera de escultor eran las siguientes: Dibujo Preparatorio; Taller de Artes Plásticas I y II; Historia General del Arte I y II; Dibujo de Figura; Dibujo del Desnudo; Taller de Escultura; Laboratorio de Materiales de Escultura; Historia del Arte Precortesiana y Colonial; y Taller de Dibujo. Los temas correspondientes a la práctica en los talleres indicaban cuestiones como:

"Estudio con modelos vivos, de diferentes edades, estructuras a escala y estudio de figuras de desnudo y vestido, ejercicio de composición previo boceto, pruebas repentinas con modelo, amplificación a escala, retrato, etc."'6

En los talleres de Escultura de los años 60 de la (ENAP), se establecieron diferentes materias en las que se indicaba la finalidad de las mismas: Figura Humana, Diseño Abstracto, Iniciación a la Experimentación, Desarrollo de la Técnica y Uso de todos los Materiales, Práctica de Modelado; Talla en Madera, Escultura directa en Metales, Esmaltes y Fundición.

En todos ellos se irán incorporando poco a poco bibliografía, generalmente manuales técnicos, como los de soldadura; o el manejo de materiales plásticos; además se añadirán otras asignaturas teóricas y de talleres como: Dibujo Constructivo, Dibujo de Desnudo, Anatomía Comparada, Perspectiva, Teoría de la Composición, Taller de Dibujo de Composición, Geometría aplicada a la Escultura, Maquetas, Teoría de la 
Arquitectura, Elementos de Urbanismo, Taller de Escultura Monumental, Taller de Escultura y Composición en Relieve, Historia General del Arte, Precortesiana y Colonial, Arte Moderno y Contemporáneo, Sociología del Arte, Francés, Técnica General de la Enseñanza, Cerámica, Fundición y Talla en Madera.

En 1966, se presentó por parte del profesor Jorge Tovar Santana y de la profesora Elizabeth Catlett de Mora, un "Plan de Estudio y Programa para la Carrera de Escultura", en cinco años, que fue aprobado por "el acuerdo en junta de colegio de profesores de escultura y en presencia de varios invitados, profesores y alumnos de la especialidad, el 28 de julio de $1966 "$ ".

En este Plan de Estudio para la Escultura, que era muy completo, se indican los objetivos generales y también por semestres. Los temas que se incluyen contemplan: el análisis compositivo de figura humana, ejercicios en bocetos (...), copia e interpretación escultórica, relieves y medallas, talla en piedra, conocimiento y fabricación de herramientas (...), distintos materiales, visitas a museos y galerías, etc.; se especifican ejercicios de bocetos (modelado, tallado y dibujo), y se indican ocho diferentes talleres que apoyarán a los maestros de escultura encargados "de la crítica estética constructiva", con "maestros técnicos" capacitados para resolver los problemas específicos de su especialidad: Cerámica, Talla en Piedra, Moldaje (moldes) y Vaciado, Talla en Madera, Fundición, Materiales Nuevos (plásticos), Metales y Esmaltes.

Este plan de estudios no llegó a prosperar, originando una crisis y la deserción entre los estudiantes que se fue acentuando en poco tiempo, obligando a efectuar pequeños cambios en las materias, que llevaron finalmente a una revisión profunda de los planes de estudios en 1970.

En el taller de Escultura llamado Iniciación I de 1967, se requería en la preparación del alumno, que el curso lo condujera a los distintos objetivos marcados:

De forma progresiva a los cuatro aspectos que abarca la enseñanza de la Escultura que son: Concepto formal, desarrollo de la inventiva y creatividad, el aprendizaje del oficio básico y despertar o afirmar la vocación del alumno. (Archivos $\mathrm{S} / \mathrm{C}$ de la ENAP, años 60 cajón 116 [50]) 
También en el mismo programa se propone una serie de actividades específicas sugeridas por el maestro, que contemplaba el modelado de forma transitoria para algunos ejercicios, la fabricación de molde perdido en yeso, así como el modelado definitivo en diferentes técnicas (terracota, morteros y cemento, estuco, papel, yeso, etc.) complementándose con la visita a sitios como museos, salas de exposiciones, estudios privados y películas que no se especifican.

Por su parte las Asignaturas del Ciclo Superior aplicado en 1967, que complementaban el Plan General de Estudios para la Escultura, incluía: Historia del Arte Moderno y Contemporáneo; Historia de Arte Moderno y Contemporáneo en México; Sociología del Arte I y II; Taller de Dibujo y Composición III y IV; Escultura III (Clave B-5), llamado Taller de Escultura y Composición en Relieve, que se aplicaba como segundo del ciclo profesional; Taller de Escultura VII y VIII; Maquetas I y Teoría de la Arquitectura I.

Para este Plan modificado se creó, el "Título Profesional de Maestro en Artes Plásticas Especialidad Escultura", con una duración de 12 semestres; existiendo también el "Título Profesional de Carrera de Escultor", con una duración de 10 semestres y los diplomados con una duración de 8 semestres.

En la reforma que se da en a finales de los 60, se definen los parámetros generales de las asignaturas y se incorporan otras nuevas como: Educación Visual, Diseño Básico, Diseño Gráfico y Arte Cinético; además los Talleres de los últimos semestres, que en un momento dado, se convierten en "Talleres de Experimentación Plástica I y II", que en el caso de la Escultura, correspondieron a los de Talla en Madera y Talla en Piedra; en ellos se pretendía acercar a los alumnos a los trabajos profesionales externos, individualmente o en equipo, en donde pudieran resolver en la práctica los diferentes problemas propios de la Escultura de Caballete o la integrada a la Arquitectura a la que se nombró Escultura Monumental:

Escultura Monumental: El Taller de Experimentación Plástica, tiene la finalidad de proporcionar al estudiante avanzado, un sitio donde pueda investigar y experimentar sobre nuevos materiales, técnicas y formas de expresión, sin ninguna limitación creativa. En él cuenta 
con asesoría de un Maestro y Técnicos en Escultura, Pintura y Arquitectura con el fin de realizar estudios de experimentación e integración plástica. Al mismo tiempo este taller tiene el concepto de Taller de producción a Nivel Profesional donde se podrán realizar trabajos de encargo. $(\ldots)^{8}$

En 1970, se hizo una reforma notable en la ENAP, como respuesta a la crisis que se había dado con el plan anterior. Esta reforma originó la Licenciatura en Artes Visuales y en 1971 se aplicarían finalmente los nuevos Planes que sustituían las carreras de Pintura, Escultura y Grabado; aunque estas se conservaban como áreas dentro de los estudios.

En 1975, con el director Antonio Ramírez Andrade, se dieron otros pequeños ajustes a los planes de estudio, aunque conservando la parte sustancial de los anteriores. Prácticamente desde esas fechas el Plan de Estudio y las Asignaturas, no cambiaron mucho durante los siguientes 30 años, aunque se fueron actualizando y revisando en diferentes momentos.

Los Programas de las Asignaturas que fueron definidos en lo general, se adecuaron desde entonces, en lo particular, a partir de los distintos profesores y maestros contratados que imparten las materias. Estos se pueden dividir todavía hoy en día, entre los que imparten "las prácticas o talleres y en los ocupados de las teóricas, (...) Las dos ideas centrales antes mencionadas son: la teorización de las prácticas y la "pragmatización" de las teorías." (Acha: 2004. P.126) Se puede aseverar así mismo, que los distintos profesores plantean, en los Talleres y

Laboratorios, sus respectivos Programas desde la perspectiva de la libertad de cátedra y de acuerdo a sus intereses personales; con ello, dentro de los múltiples Programas, coinciden las nuevas tendencias junto a las tradicionales.

En la Licenciatura en Artes Visuales de la ENAP/UNAM, en el año 2013, hay como planta docente en el área de Escultura, un cuerpo colegiado de 14 profesores, formado por un doctor, once con maestría y dos con licenciatura; tres de estos últimos profesores con maestría, se encuentran cursando el doctorado en Artes y Diseño de la ENAP. 


\section{Reflexiones actuales}

Como reflexión al respecto de todo lo anterior, se puede indicar que actualmente como profesor de escultura, en una institución de educación superior ligada a la Universidad, no se forman solamente artistas del modo tradicional, sino que esta enseñanza responde a funciones y fines diferentes. En ellas se debe aspirar a poder conseguir cosas muy diversas, como es formar profesionales en posesión de conocimientos académicos amplios, tanto teóricos, como conocedores de las diferentes técnicas artísticas tradicionales y actuales, pues así les permitirá ejercer tanto una profesión libre, como dedicarse a la docencia, a la publicidad, al diseño o al montaje de escenografías por ejemplo.

La escultura tradicional y su enseñanza/aprendizaje continua vigente dentro de las escuelas de arte, a pesar de los nuevos conceptos y teorías que han ampliado enormemente su campo de acción y que se han introducido en las últimas décadas como un modo de entender el presente. Más que sustituir los procedimientos tradicionales, los nuevos conceptos, materiales y métodos, se sirven de lo anterior para experimentar el presente.

Desde luego todos los Planes de Estudios y Programas específicos universitarios son susceptibles de ser mejorados. Esto se ha visto reflejado en la ENAP que ha realizado revisiones, adecuaciones y evaluaciones de los mismos en diferentes tiempos, incluyendo dentro de estas, la reciente modificación de la Licenciatura en Arte y Diseño del 2013.

No se debe olvidar que el hecho artístico tiene mucho de intuitivo, y de experimental en el manejo manual y metódico de las distintas técnicas, aunque en la enseñanza superior se apoya o complementa con la teoría, que es el producto neto de las universidades; hay que tener presente que en su origen más íntimo, el arte surge a través de la práctica y de la manipulación de los materiales propios en los talleres o laboratorios.

\section{La investigación en las Artes Visuales}

Otro aspecto importante para la reflexión sobre la educación artística 
superior en México, que se presenta a continuación, es el concerniente a la investigación desde la perspectiva de las Artes, sobre todo teniendo en cuenta las pautas y referencias marcadas en Europa, concretamente con el establecimiento del Doctorado en las Facultades de Bellas Artes en España, a partir de los años 1984/85.

De algún modo lo sucedido en España sirvió de pauta y modelo, para que en agosto del 2011, se instaurara en la ENAP un Doctorado en Artes y Diseño apoyado en otras dos instituciones de la UNAM, el Instituto de Investigaciones Estéticas y la Facultad de Arquitectura.

Una adecuación importante en los primeros planes de estudio del Posgrado en Artes Visuales de la UNAM/ENAP, se dio en 1999, cuando los estudios de Maestría se modificaron y se preparó un nuevo reglamento de posgrado, para que otras instituciones se vincularan con el Posgrado de la ENAP (La Facultad de Arquitectura y el Instituto de Investigaciones Estéticas de la UNAM) y se pudieran aplicar convenios con otras universidades tanto nacionales como extranjeras.

Como ejemplo, está el que se dio con la Facultad de Bellas Artes de la Universidad Politécnica de Valencia, en donde se formaron durante más de diez años los primeros Doctores en Bellas Artes, pertenecientes a la planta docentes de la ENAP, con lo que se fortaleció la investigación de alto nivel, buscándose desde entonces la creación de un Doctorado en Artes Visuales, que finalmente fue aprobado por el Consejo Universitario de la Universidad Nacional Autónoma de México el 26 agosto del 2011.

En el día de hoy (2013), en el posgrado de la ENAP, hay como plantilla docente del área de Escultura un total de 12 profesores: cinco doctores, seis maestros y un licenciado.

Son variadas y distintas las cuestiones que tienen que ver con la investigación en arte, ya que esta abarca diversas perspectivas, tanto la utilizada por algunos artistas para explicar su producción profesional, como lo correspondiente a su enseñanza en los ciclos superiores de la educación artística y que tienen como meta principal la producción de una tesis doctoral, generalmente apoyada en un documento escrito y en una metodología historicista no siempre afinada. 
..."En torno a ella (la investigación artística) se organizan simposios y se fundan revistas, en su nombre se convocan becas y puestos académicos, la crítica y los propios artistas la invocan para explicar y defender su trabajo."9

La Investigación, en todas las áreas del conocimiento, es una de las vertientes más importante en las humanidades y las ciencias de la Universidad Nacional Autónoma de México (UNAM), que se refleja también de manera clara en el país.

A pesar de los presupuestos insuficientes, que dentro de la investigación en general se destinan al arte, en la Escuela Nacional de Artes Plásticas (ENAP) encontramos que en los estudios del Posgrado en Artes Visuales, existe un interés sustancial y creciente hacia las distintas orientaciones que se dan dentro de este rubro; como se ve por ejemplo en la temática de las distintas tesis de la Maestría en Artes Visuales, que comprenden las áreas de Pintura, Escultura, Dibujo, Arte Urbano y Gráfica o también lo que concierne al estudio, clasificación y conservación del Acervo de la Antigua Academia de San Carlos, que se realiza en el Departamento de Curaduría.

La investigación puramente plástica, pertenece a un campo fundamental libre, que no tiene límite ni en la elección de temas ni en el método elegido para desarrollarlo. El acercamiento teórico a la escultura en la universidad se da principalmente en las investigaciones destinadas a la elaboración de las Tesis de Licenciatura, Maestría y con mucho más rigor en las Doctorales. De estas últimas en la ENAP, algunas investigaciones conducentes al Doctorado en Artes y Diseño, se plantearon a partir de los proyectos comenzados a partir del convenio con la Facultad de Bellas Artes de la Universidad Politécnica de Valencia, que no concluyeron, y que se están realizando aún en la actualidad, retomándolos con la planta de tutores que forman parte de la ENAP/UNAM; otros proyectos nuevos han ido surgiendo de las dos últimas convocatorias al Doctorado.

Con seguridad a medida que se terminen y presenten como tesis concluidas las primeras investigaciones conducentes al Doctorado, estas tendrán que pasar por un periodo de prueba y ajuste en el que se evaluará la metodología utilizada, los criterios de evaluación, las 
aportaciones teóricas y artísticas, así como los distintos parámetros que se marquen para asegurar la calidad y seriedad de las mismas. Uno de los intereses principales marcados en el doctorado de la ENAP, es vincular el apartado de la producción artística con el de la investigación teórica, problema actual aún vigente y sin resolver convenientemente en las Artes Visuales.

En todas las investigaciones sobre arte, sustentadas en un documento escrito, conviene separar el aspecto productivo del meramente reflexivo, que es primordial a la hora de ponerse a escribir o describir una idea o concepto; esto es indispensable para el desarrollo de la tesis. Por ello es necesario el apoyo y la dirección que reciben los doctorandos de los tutores académicos, que sirven de guía y orientación en el complejo proceso de investigar y escribir el documento.

Desde una perspectiva humanista se pretende formar al estudiante, con un sentido ético y de servicio social, de acuerdo a las necesidades actuales del país. Se busca también que los egresados puedan ejercer la producción artística profesional dentro de diferentes campos o que pueda teorizar o dedicarse a la docencia, si así lo requiere

Las primeras vertientes de investigación en el Posgrado de Artes Visuales de la ENAP/UNAM, se formularon a partir de una consulta al profesorado y una revisión de los intereses encontrados en las tesis de maestría en Artes Visuales y son señaladas a modo de orientación en la página de Internet 2005, como siguen, aunque se continúan ampliando:

"Teoría, análisis y crítica en las artes visuales el diseño y la comunicación visual.

Experimentación técnica y en materiales.

Discurso museográfico y dinámicas museológicas.

Nuevas tecnologías aplicadas a las artes visuales.

Didáctica de las artes visuales, el diseño y la comunicación visual.

Métodos y sistemas en el diseño y la comunicación visual.

Tecnología para el diseño y la comunicación visual.

Enfoques historiográficos de las artes visuales, el diseño y la comunicación visual.

Enfoques formales, semióticos y perceptuales de las artes visuales, el diseño y la comunicación visual. 
Teoría y análisis del proceso creativo.

Estudio de la cultura a partir de las manifestaciones visuales.

Documentación y conservación del acervo artístico de la Antigua Academia de San Carlos.

Documentación y conservación de la biblioteca de la Antigua Academia de San Carlos.

Medios no convencionales en las artes visuales, el diseño y la comunicación visual."

Las líneas de Investigación desarrolladas en la Facultad de Arquitectura para las Artes Visuales de la ENAP, son las siguientes:

"Análisis, Teoría e Historia de la Arquitectura.

Enseñanza de la Arquitectura.

Historia y presente de la Ciudad de México.

Vanguardia en la Arquitectura Nacional e Internacional.

Diseño asistido por computadora.

Diseño y Medio Ambiente.

Arquitectura y Sociedad.

Nuevas tendencias en la Arquitectura.

Restauración Histórica.

Teoría y Crítica de la Restauración.

Patrimonio Cultural y Calidad de Vida.

(WWW del posgrado en Artes Visuales de la ENAP/UNAM (2005).

En referencia a las Tesis de Maestría en Artes Visuales de la ENAP, desde la primera presentada en 1980 hasta el 2011, hay registradas en la biblioteca del Posgrado, 69 tesis relacionadas directamente con la Escultura y cuatro de Arte Urbano que se podrían incluir en el mismo campo. Ver Anexo I.

En estas se abordan muy diferentes temas que se fueron desarrollando y presentando a lo largo de 31 años. Se puede encontrar en el Anexo I, al final de este artículo y a modo indicativo, la lista con los títulos y el año de presentación de las Tesis relacionadas con la Escultura.

Estos trabajos, con el tiempo, se han ido haciendo más adecuados a los requisitos de una investigación especializada y universitaria, se han fortalecido las distintas metodologías aplicadas, el manejo de la información y su presentación analizada y comparada, las citas de fuentes, las aportaciones y las propuestas, etc., “...la metodología del 
proyecto se alimenta fundamentalmente de la psicología, la filosofía, la sociología y la práctica profesional." (Esteve: 2001. p. 10), de ahí se desarrolla y surge "el proceso mental desde el que se aborda dicho problema” (ídem. p.107).

Podríamos afirmar que, con el tiempo, se han ido afinando $y$ profesionalizando las estrategias y las trayectorias a seguir para poder solucionar los problemas "con unos métodos y desde una perspectiva metodológica determinada" (ídem), todo ello enfocado con mayor o menor acierto, al desarrollo de las tesis de Artes Visuales.

Esto ha sido posible cada vez de mejor modo, por la mayor experiencia adquirida de los tutores en la dirección de los temas, sobre todo en cuanto a los requisitos específicos de la metodología y la formalidad en su presentación.

En un porcentaje significativo las propuestas de investigación presentadas en la Maestría en Artes Visuales de la ENAP, tienen que ver directamente y de un modo obvio con la obra personal, lo cual en ocasiones significan y expresan un conflicto ético en cuanto a la imparcialidad de los intereses y métodos utilizados en una la investigación científica más pura; algunas de estas investigaciones se definen como tesis teórico-prácticas y están condicionadas por una metodología específica que desarrolla la reflexión sobre la obra producida, buscando aspectos que puedan aportar algo importante al conocimiento, en cuanto a técnicas y materiales, nuevas tecnologías, aplicaciones didáctica, etc.

Dentro de los intentos y trabajos sobre la investigación artística, destacaríamos para clarificar un poco más este asunto, las anotaciones y diferencias, que hicieron algunos especialistas que participaron dentro del contexto del: ler. congreso internacional Nuevos Procedimientos Escultóricos, Valencia 2002 ¿Qué es la escultura, hoy? ${ }^{10}$, y años después en el seminario: En torno a la investigación artística. Pensar y enseñar arte: entre la práctica y la especulación teórica, realizado en el Museu d'Art Contemporani de Barcelona (MACBA) el 9 y 10 de abril de 2010 y que publicaron sus ensayos ${ }^{11}$ en diferentes textos.

Estos autores distinguen entre hacer obra artística dentro de una experimentación plástica, conducida como investigación propia, creativa y personal, y que en principio poco aporta al enriquecimiento 
social establecido, mientras no se incorpore en el mercado del arte a través de galerías y exposiciones. Por otro lado, lo que sería la reflexión comparada y apoyada en diversas ciencias y pensamiento humano como: la Estadística, la Sociología, la Filosofía, la Antropología, la Historia, etc., productora y conducente en mayor medida a crear un documento escrito, convertido en una tesis doctoral, en donde se aporta algo más "que objetos", al conocimiento general de la sociedad; aunque esto último irónicamente, pueda ser una contradicción en sí mismo, ya que la tesis doctoral, como texto encuadernado, se convierte en un objeto, a modo de libro objeto, con volumen y peso propio y por otro lado, de acuerdo al refrán, hablando de objetos e imágenes, "una imagen vale más que mil palabras".

\section{Conclusiones}

Como ha sido presentado a lo largo de esta exposición, a modo de recapitulación, se puede indicar que desde su incorporación a la UNAM, los Planes de Estudio generales y los Programas de trabajo particulares, tanto en la Licenciatura como en la Maestría y Doctorado, que se imparten bajo la libertad de cátedra, se convirtieron en los principales instrumentos para organizar la enseñanza artística dentro de la ENAP; hoy en día esto se puede observar definiendo con claridad los nombres y objetivos generales y particulares de las materias, la metodología a emplear en su aplicación, junto a las fuentes bibliográficas que sirven de apoyo, así como en la manera de evaluar los resultados y en la adecuada programación del calendario semestral.

La ENAP como otras universidades mexicanas, está comprometida como institución, a la revisión constante y adecuación continua de los Planes y Programas, a fin de actualizarlos de acuerdo a los nuevos tiempos, siendo esto un mecanismo dinámico y efectivo para la enseñanza superior de las Artes Visuales.

Dado que en la escultura, el peso, las dimensiones y los distintos materiales utilizados deben manipularse en lugares adecuados y con las herramientas y la técnica precisa, los espacios de trabajos, talleres y laboratorios, deben ser construidos teniendo en cuenta la seguridad de acorde a las necesidades particulares, y preferiblemente contar con la 
adecuada amplitud y divisiones correspondientes, con una buena iluminación y ventilación, suelos y paredes resistentes así como todos los servicios complementarios.

La velocidad y los tiempos de trabajo de cada técnica y material utilizado que requiere de un aprendizaje práctico y artesanal especializado, es variable y no siempre igual en todos los casos: ya sea la tradición de modelar arcilla o plastilina, la cera para fundición, tallar o cortar madera o piedra, fundir o forjar y soldar metales, realizar moldes en yeso o resinas y plásticos, junto a las nuevas tecnologías y posible manipulación de otras, gran cantidad y variedad de materiales no tan tradicionales que se han ido incorporando, junto a los nuevos conceptos que interactúan en el campo expandido de la escultura. La necesidad de contar con espacios y equipos acondicionados se convierte en una obligación para las instituciones donde se imparte la educación superior.

En el año 2011, siendo la UNAM/ENAP la que marca principalmente la pauta México y Latinoamérica, se podían encontrar veinte universidades que ofrecían estudios superiores correspondientes a la Licenciatura en Artes Visuales. En sus facultades y escuelas correspondientes, solo unas pocas comenzaban a ofrecer maestrías y únicamente dos un doctorado. En el Anexo II se presentan las veinte instituciones de educación superior que actualmente imparte la licenciatura en Artes Visuales.

Definitivamente en la república Mexicana con sus altibajos y circunstancias propias, han ido surgiendo en los últimos años, diferentes centros de enseñanza del arte en un nivel superior, que se han esforzado para adaptarse a los nuevos tiempos de comunicación global, incorporando los requisitos para estar al día con respecto a otros países de Latinoamérica y Europa.

\section{Notas}

1 Tous, F. J. (2012). La enseñanza de la escultura en México Editorial Académica Española; Saarbrücken, Alemania.

${ }^{2}$ Don Manuel Tolsá sustituyó al primer escultor llegado en 1788 don José Arias, quien había fallecido ese mismo año. Puede encontrarse información sobre Tolsá en: VVAA (1998). Manuel Tolsá. Nostalgia de lo "antiguo" y arte ilustrado. México-Valencia; 
Catálogo. UNAM. Generalitat Valenciana; Imprenta Pentagraf, S.L.; México 1998.

3 Citado de: "Puntos acordados en las juntas del año de 1803" en la Real Academia de las tres Bellas Artes de San Fernando de Madrid por: Navarrete, Esperanza (tesis doctoral) (1999): La Academia de Bellas Artes de San Fernando y la pintura en la $1^{a}$ mitad del siglo XIX; Fundación Universitaria Española, Madrid.

4 Moreno, Salvador. (1969). El Escultor Manuel Vilar; Instituto de Investigaciones Estéticas; UNAM, México.

${ }^{5}$ Programa para las enseñanzas de Talla directa en Madera en el primer año de taller libres, a cargo del Prof. Guillermo Toussaint. Archivos Sin Clasificar de la Academia de San Carlos.

${ }^{6}$ Archivos sin Clasificar de la ENAP, años 60. "Prácticas" del Programa de escultura para los tres años profesionales de la Carrera de Escultor. 1959. Caja 116 [50]

7 Ídem. Plan de Estudio y Programa para la Carrera de Escultura año 1966.

8 Archivos sin Clasificar de la ENAP, años 60. Caja 116 [50]: Taller de Escultura Experimentación Plástica I y II (Clave B-10).

9 VVAA. (2010). En torno a la investigación artística. Pensar y enseñar arte: entre la práctica y la especulación teórica; Edt. Museu d'Art Contemporani de Barcelona (MACBA); España. P.9

10 Martínez Barragán, Carlos. (2002). "Investigación científica o experiencia plástica" en ¿Qué es la escultura hoy?

11 Ídem.

\section{Referencias}

Acha, Juan. (2004). Educación Artística escolar y profesional; Edt. Trillas, México, $2^{\mathrm{a}}$ edc.

Azcue Brea, L. (1992). "Escultura. Teoría y Docencia”; Real Academia de BBAA de San Fernando; Madrid.

Brown, Thomas. (2010). "Haz lo propio" pp. 87-102 en VVAA: En torno a la investigación artística, (MACBA), Barcelona,

Brown, Thomas A. (1976). La Academia de San Carlos de la Nueva España. T. I Fundación y Organización; Traducido por María Emilia Martínez Negrete Delfis; SEP; México. 175 pp. il.

ídem. (1976). La Academia de San Carlos de la Nueva España. T. II La Academia de 1792 a 1810. Traducido por María Emilia Martínez Negrete Delfis; SEP; México. 190 pp.

Del Villar Quiñones, P. (Director: Román de la Calle; tutor Dr.

Sebastián Miralles Puchol). (2003). Análisis de la creatividad en el proceso escultórico. Una propuesta Teórico-Metodológica; Universidad Politécnica de Valencia, Facultad de Bellas Artes San Carlos, Departamento de Escultura; Valencia. 
196 F. J. Tous - La enseñanza de la escultura en México

Dieter, Lesage. (2010). "Portafolio y suplemento" Pp.67- 85 en VVAA: En torno a la investigación artística. (MACBA)

Efland Arthur D. (2002). Una Historia de la educación del arte.

Tendencias intelectuales y sociales en la enseñanza de las artes visuales; (A History of Art Education, 1990) Ediciones Paidos Ibéricas SA, Barcelona.

Efland y otros. (2003). La educación en el arte posmoderno; (Postmodern Art Education; The National Art Education Association; Virginia, USA, 1996) Traducido por Lucas Vermal; Ediciones Paidós Ibérica, S.A. Barcelona.

Esteve de Quesada, A. (2001). Creación y Proyecto. El método en diseño y otras artes; Institució Alfons el magnànim. Diputació de València.

García, D. (2010). "Más mística que racionalista, alcanza verdades que la lógica no puede alcanzar." Pp.59-65 en VVAA. (2010). En torno a la investigación artística, (MACBA), Barcelona.

Garibay Sida, Roberto. (1990).Breve historia de la Academia de San Carlos y de la Escuela Nacional de Artes Plásticas; División de Estudios de Posgrado/Escuela Nacional de Artes Plásticas/UNAM; México.

Echevarria, Guadalupe. 2010. "There is plenty of room at the bottom" pp. 45-58 en VVAA. (2010). En torno a la investigación artística, (MACBA), Barcelona.

Martínez, E. (2007). "Creación e investigación en arte” pp.14-17, en VVAA: catálogo "En memoria de Bruce Wallas"; CAM obras sociales; UPV, del 6 al 26 de febrero 2007,

Masó, A. (2004) Qué puede ser una escultura (Edición revisada y

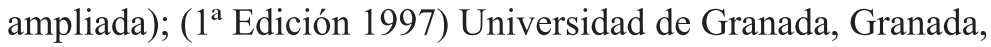
España.

Matilla, J. M. (1989): “el escultor: el modelo, la técnica y la idea” en: VVAA (Catálogo): La formación del Artista: De Leonardo a Picasso; Real Academia de Bellas Artes de San Fernando; Calcografía Nacional, Madrid.

Michaud, Yves. (1999). Enseigner L'Art? Analyses et réflexions sur les écoles d'art; Ed. Jacqueline Chambon; Nîmes, Francia. 
Pevsner, Nikolaus, (1982) epílogo de Francisco Calvo Serraller. Las Academias de Arte. Pasado y Presente; (Academies of Art. Past and Present) Traducido por Margarita Ballarín; Edt. Cátedra, Madrid.

Pinedo Herrero, C.; E. Mas Zurita y A. Mocholí Roselló. (2003). La Enseñanza de las Bellas Artes en Valencia y su repercusión social. 250 años; UPV; Valencia.

Rodríguez Prampolini, I. (1997) La crítica del arte en México en el siglo XIX. T. I, II y III; UNAM, IIE, México.

Rodríguez García, S. (1988). La investigación y la tesis doctoral en Bellas Artes; Facultad de Bellas Artes de la Universidad Politécnica de Valencia, Valencia.

Tous Olagorta, Francisco J. (2012). La enseñanza de la escultura en las Artes Visuales. Historia y análisis de los planes de estudio y programas vigentes en México. Editorial Académica Española; Saarbrücken, Alemania.

VVAA. (2002) ¿Qué es la escultura, hoy? 1er. Congreso Internacional Nuevos Procedimientos Escultóricos; Grupo de Investigación UPV, Valencia.

VVAA. (2003). La enseñanza de las Bellas Artes en Valencia y su repercusión social. 250 años; Catálogo. Valencia.

VVAA. (1998) La Investigación en Bellas Artes. Tres aproximaciones a un debate; Grupo Editorial Universitario; España.

VVAA (catálogo). (2000). Escultura mexicana de la academia a la instalación; Consejo Nacional para la Cultura y las Artes; Landucci Editores; México, D.F.

VVAA. (1989). La formación del artista: De Leonardo a Picasso. Aproximación al estudio de la enseñanza y el aprendizaje de las Bellas Artes; Catálogo. Real Academia de Bellas Artes de San Fernando; Calcografía Nacional; Madrid.

VVAA. (marzo-abril, 1990). La Escuela mexicana de escultura: Maestros fundadores; Consejo Nacional para la cultura y las Artes, Instituto Nacional de Bellas Artes, Museo del Palacio de Bellas Artes; México, D.F.

VVAA. (2010) En torno a la investigación artística Pensar y enseñar arte: entre la práctica y la especulación teórica; Catálogo del 
Seminario organizado por el MACBA el 9 y 10 de abril de 2010; Dep. de Publicaciones del MACBA y Servei de Publicacions de la Universitat.

\begin{abstract}
Anexo I
Listado de tesis de Maestría en Artes Visuales presentadas en la ENAP desde 1980 al 2011:

1.Escultura en el espacio urbano (1980)

2.La escultura en la sociedad de clases. (1982)

3.Arte como verdad. (1989)

4.Experimentación y desarrollo formal en escultura monumental para espacios abiertos. (1989).

5.El rescate de espacios urbanos ociosos, proyecto: Cipreses IK.(1990)

6.Mural escultórico: un caso experimental de material de desecho arqueológico. (1990).

7.Influencia de elementos artesanos-populares en la estructura artística de tres artistas colombianos en la década de los ochenta.(1991)

8.Un estudio morfomicoerótico escultórico de la sexualidad del mexicano; (1991).

9.Brasilia, utopía del siglo XX: Forma y función de un arte integral. (1992).

10.Expresión plástica de la cerámica por la repetición, el punto, la línea y el contorno de la geometría: cerámica y arte óptico. (1994).

11.El muro como elemento escultórico, un aporte mexicano. (1994).

12.Introducción a las Artes Visuales y al diseño gráfico nivel mediosuperior de la Universidad de Guanajuato. (1994).

13.Integración de arte, ciencia y tecnología en objetos estrictamente clasificados de 1950-1990. (1994).

14.Un mensaje visual a través de la realización de objetos utilizando frutas, vegetales y material inorgánico. (1995).

15.Aproximación a la escultura. Relaciones e interrelaciones de la forma. (1995).

16. Tintes naturales mexicanos en la producción de tapiz artístico.

Análisis de los tintes naturales mexicanos en algodón, henequén, lana y su viabilidad de aplicación en la actualidad. (1996).

17.El icono escultórico católico como campo artístico contemporáneo. (1996).

18.El caballo en el arte. Anatomía del caballo desde el punto de vista artístico. (1997).
\end{abstract}


19.Las máscaras de la ciudad, cazadores urbanos. (1998).

20.Formas blandas. (1999).

21.Felipe Sojo y la Academia de San Carlos. (1999). (Tesis de licenciatura)

22.El acero como material de expresión. (1999).

23.Espacio y medios alternativos. (2000).

24.La paciencia como método. (2000).

25.La superficie pictórica del ensamblaje (una propuesta personal). (2000).

26.Idealidad y realidad en la representación del cuerpo femenino, algunos casos del arte contemporáneo. (2001).

27.Las cabezas inútiles: El homo sistematizado. (2001).

28.El espacio como escultura o la escultura como espacio. (2001).

29.Iluminación en la escultura, el signo de la luz. (2001).

30.Materiales alternativos en la escultura, los polímeros. (2002)

31.Breves comentarios entorno al espacio y el tiempo. El objeto artístico. (2002).

32.Aspectos bidimensionales en la escultura mexica. (2002).

33.La influencia de la tauromaquia en las artes plásticas, concretamente en la escultura. (2003).

34.La producción escultórica integral. (2003).

35.Artes visuales y silencio (lenguaje, intertextualidad y cultura contemporánea). (2003).

36.La imitación o-culta: establecimiento de un proceso de análisis que permita comparar las intenciones de una propuesta escultórica con los resultados obtenidos en una exposición. (2004).

37.El agua como un elemento estético en la escultura. (2004).

38.La silla como objeto de introspección. (2004).

39.Señales arte público, revisión de las variables de su producción. (2004).

40.La transformación escultórica de materiales de desecho. Análisis de cinco obras de la serie REUSARTE (1999-2004).(2004). 
41.De lo personal en el arte y de lo ambiental en las Artes Visuales. (2005). (Contiene un CD)

42.La perspectiva artística femenina de nueve escultoras mexicanas del siglo XX-XXI nacidas entre 1950-1980, tres generaciones.(2005).

43.La transgresión de la forma. Teoría y propuesta plástica acerca de la conceptualización del cuerpo grotesco en la escultura contemporánea. (2007). (Contiene un CD)

44.La escultura solar. (2007).

45.La fenomenología en la escultura contemporánea. (2007).

46.Símbolo y escultura, especialidad común y encuentro con lo sagrado. (2008).

47.Arte y utopía en tres momentos del movimiento social: de la forma a la resignificación de la palabra. (2008).

48.La apariencia como recurso y posibilidad plástica en materiales escultóricos en propuestas actuales (elemento de mi obra plástica). (2009).

49.La maqueta como escultura. Modelos a escala. (2009).

50.La experimentación técnica y el uso de materiales industriales (látex, resinas y espuma de poliuretano) en la escultura mexicana contemporánea 1960-2007. (2009).

51.Antártica: Diseño y elaboración de una propuesta plástica a partir del análisis de la instalación como planteamiento escenográfico. (2010). 52.La escultura de Armando Amaya. Documentación de una técnica heredada de la Escuela Nacional de Pintura, Escultura y Grabado. (2010).

53.Escultura filiforme en ferrocemento y concreto reforzado. Propuesta personal. (2010).

54.Las huellas del tiempo. Vestigios de la naturaleza en los materiales utilizados en un proceso escultórico. (2010).

55.Investigación de nuevas pátinas para reforzar el lenguaje plástico de la escultura en bronce. (2010).

56.Investigación documental del acervo escultórico de la Academia de San Carlos y reproducción de la Victoria de Samotracia tamaño natural. Testimonio de su objetivo didáctico. (2010).

57.El plato de hoy: El artista como enseñante de conceptos visuales... y su resultado más allá de la maquila. (2010). 
58.La textura como elemento plástico formal con características bidimensionales y tridimensionales para crear sensaciones espaciales en el acero. (2010).

59.Presencia de la escultura abstracta en el arte público de Morelia. (2010).

60.El juego de lo permanente. Una propuesta escultórica experimental, docente y de investigación. (2011).

61.Análisis formal en la escultura policromada Novohispana, una propuesta para su estudio. (2011).

62.Elementos sígnicos y matéricos de la naturaleza de la madera y sus posibilidades de expresión y producción plástica en lo escultórico. (2011).

63.Los procesos de ideación y planeación en proyectos artísticos, análisis y documentación. (2011).

64.Construcción del personaje y la escena en escultura. (2011).

65.La luz artificial como concepto plástico en la escultura (una propuesta personal). (2011).

66.Lluvia sobre el puente, escultura-arquitectura. (2011).

67.Interpretación del triángulo semiótico de Charles S. Peirce en la producción escultórica en madera de José Luis Morales Jurado.(2011). 68.De la escritura bidimensional al diseño escultórico. (2011). 69.Reivindicación del objeto escultórico en cerámica a través de la instalación (propuesta personal). (2011).

Tesis de Arte Urbano relacionadas:

1.Intervenciones escultóricas temporales. Un medio de incisión en el espacio público. (2006).

2.Cuerpo y ciudad: el cuerpo humano en el arte público. Performance, body paint, estatua viviente, instalación y los actosperformáticos.(2009). 3.El cuerpo femenino en el performance a manera de ritual personal. (2010).

4.La ruta de la amistad. Un hito del arte urbano de México. (2011).

\section{Anexo II}

Veinte instituciones de enseñanza superior mexicanas en donde se imparte la licenciatura en Artes Visuales: 
1.Universidad Nacional Autónoma de México. Escuela/Facultad Nacional de Artes Plásticas. D.F. UNAM/ENAP

2.Escuela Nacional de Escultura, Pintura y Grabado, "La Esmeralda", D.F.

3.Universidad de Guanajuato, Guanajuato.

4.Universidad Autónoma del Estado de México. Toluca.

5.Universidad Veracruzana. Xalapa, Veracruz.

6.Universidad de Guadalajara.

7.Universidad Autónoma de Baja California.

8.Universidad Autónoma de Puebla.

9.Universidad Autónoma de Yucatán-Facultad de Arquitectura.

10.Universidad Juárez del Estado de Durango.

11.Universidad Autónoma de la Laguna (en Torreón) y en (Coahuila)

12.Universidad Autónoma de Nuevo León (Monterrey)

13.Universidad Autónoma de ciudad Juárez. (Chihuahua)

14.Universidad Autónoma de Chihuahua.

15.Universidad Autónoma de Yucatán.

16.Universidad Autónoma del Estado de Hidalgo.

17.Instituto Allende. (Guanajuato)

18.Universidad de Montemorelos. (Nuevo León)

19.Universidad Michoacana de San Nicolás de Hidalgo (Michoacán) 20.Universidad Autónoma del Estado de Morelos.

Dr. Francisco Javier Tous Olagorta: Profesor Titular C de Tiempo Completo Definitivo, Escuela Nacional de Artes Plásticas / Universidad Nacional Autónoma de México, Posgrado en Artes Visuales - Departamento de Escultura -, México, D.F.

Contact Address: Calle Bosque del Centenario, $\mathrm{n}^{\circ}$ 32, La Herradura. C. P. 52784. Estado de México, Mexico. E-mail: franciscotous_o@hotmail.com 
Instructions for authors, subscriptions and further details:

http://brac.hipatiapress.com

\section{Las Voces y el Cine Invisible}

Joaquim Cantalozella Planas \& Marta Negre Busó ${ }^{1}$

1) Departamento de Pintura. Universitat de Barcelona, España.

Date of publication: October 3rd, 2013

To cite this article: Cantalozella Planas, J., Negre Busó, M. (2013). Las Voces y el Cine Invisible. BRAC - Barcelona Research Art Creation, 1(2), 203-227. doi: 10.4471/brac.2013.09

To link this article: http://dx.doi.org/10.4471/brac.2013.09

\section{PLEASE SCROLL DOWN FOR ARTICLE}

The terms and conditions of use are related to the Open Journal System and to Creative Commons Non-Commercial and Non-Derivative License. 


\section{The Voices and the Invisible Cinema}

Joaquim Cantalozella Planas \& Marta Negre Busó

Universitat de Barcelona

\section{Abstract}

The eccentric, controversial figure of João César Monteiro and certain biographical episodes of mental instability are often reflected in his highly unconventional films. This article explores the more irrational facet of the auteur and analyses the links between his work and disorders of the mind. It also addresses questions related to both psychiatry and film, and places the work of the director within the context of the difficulties cinema has encountered in seeking to represent madness. The article finishes with a study of Branca de neve (Snow White) a key work in his oeuvre, in an attempt at charting the development of the themes discussed above, from a perspective that steps away from conventional cinema and which is more closely linked to the experimental nature of contemporary art.

Keywords: Cinema, psichiatry, Monteiro, Walser, outsider, contemporary art. 


\section{Las Voces y el Cine Invisible}

Joaquim Cantalozella Planas \& Marta Negre Busó

Universitat de Barcelona

\section{Resumen}

La excéntrica y provocadora personalidad de João César Monteiro, así como ciertos episodios biográficos relacionados con desequilibrios mentales, quedan reflejados, a menudo, en sus poco convencionales filmes. El presente artículo es una aproximación a la faceta más irracional del autor, y plantea un análisis de los vínculos entre su obra y los trastornos de la razón. También se abordan aspectos relacionados con la psiquiatría y el cine, y se contextualiza la obra del director dentro de la problemática de la representación de la locura en el ámbito cinematográfico. Finalmente se estudia Branca de neve, película clave dentro de su producción, para ver cómo se desarrollan los temas anteriormente abordados, desde una perspectiva que se aleja del cine convencional y que se vincula a propuestas experimentales propias del arte contemporáneo.

Palabras claves: Cine, psiquiatría, Monteiro, Walser, outsider, arte contemporáneo. 


\section{Locura certificada}

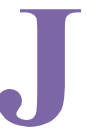

oão César Monteiro fue un cineasta polémico tanto por su obra como por su personalidad. Su cine bebió de fuentes tan diversas como la cultura popular, la antropología, la literatura, la filosofía, el cine de autor o el erotismo, por citar solo algunas de las más recurrentes. El carácter arisco, provocador y a veces impulsivo e iracundo le proporcionó una fama de hombre intratable y de enfant terrible. En Portugal, su país natal, provocó todo tipo de recelos y el arrinconamiento de la industria cinematográfica. Esta fama venía precedida por periodos de su vida en que la bohemia, la precariedad, el alcoholismo y los arrebatos públicos le convirtieron en un personaje peculiar e inclasificable. A todo ello cabría añadir el efecto que causó su transgresora producción cinematográfica y escrita. Otro episodio que, sin duda, ayudaría a fijar esta imagen fue el internamiento en un hospital psiquiátrico. Cierto es que Monterio no fomentó ni divulgó una imagen propia ligada a este hecho, rehuyendo casi siempre hablar de ello, pero creemos que proporciona uno de los puntos de partida para la comprensión de su obra, puesto que la locura y lo que Erving Goffman llamó "instituciones totales" son lugares comunes de su imaginario. Su amigo Víctor Silva Tavares consideraba que esta reclusión se debía a las presiones y restricciones sociales que sufrió el director, y criticaba la manera en que la sociedad gestiona y entiende la locura:

Le fou est juste le miroir d'une société, elle, paranoïaque. Une société qui voit dans le fou le miroir de sa propre paranoïa, et ce pourquoi elle le cache. Quand on met le fou à l'asile, c'est la même chose que mettre le voleur en prison. C'est tourniquet par lequel on expulse l'autre, par lequel on l'entrave. ${ }^{1}$

Como se verá, estas críticas coinciden con el debate, público y especializado, en torno a las prácticas psiquiátricas, concretamente en lo que refiere a la función de las instituciones de internamiento. Volviendo al caso de Monteiro, al parecer, la causa que provocó la crisis fue una ruptura amorosa que, en su texto autobiográfico $A$ minha certidão (1974), llamó "fiebres" (Monteiro, 2005, p. 58). Un amour fou que lo 
desestabilizó psíquicamente, en sus propias palabras "por el amor de esta chicha terminé loco" (Rocha, 2005, p. 110). Con esta mujer había grabado, años atrás, una película cuyos fragmentos servirían para dar inicio a Quem Espera por sapatos de difunto morre descalzo (1970) y que, en cierto modo, vertebra el hilo argumental del filme, tal y como se analizará más adelante. El paso por el manicomio, donde recibió tratamiento a base de electroshocks, lo convirtió tal y como él mismo dijo en un "loco certificado" (Rocha, 2005, p. 108). La evidente ironía que escondían estas palabras le permitía construir un personaje que funcionaba al margen de las convenciones sociales, jugando a hacerse el loco cuando más le convenía; para él estas fiebres eran un subterfugio. De hecho, la relación de Monteiro con la locura es ambigua, los episodios autobiográficos no parecen ser más que una anécdota dentro de su vida y la circunstancia de que no soportase a los locos (Gil, 2005, p. 97) dan evidencias del relativo interés que tenía por este mundo. También es cierto que las alusiones a la locura dentro de su obra son tan abundantes que acaban por constituir un cuerpo temático significativo.

El objetivo de este artículo es, pues, mostrar las claves de esta relación, tomando en consideración la figura de las instituciones, y ver cómo se valía de la impronta cultural de ambas, sus implicaciones y connotaciones, para entretejer significados que perfilarían un mundo tan singular y personal como es su cine. Con este fin y antes de pasar al análisis de la obra de Monteiro, intentaremos esbozar un marco general para inscribir la relación entre el cine y la psiquiatría.

\section{Cine y psiquiatría}

Durante buena parte de la segunda mitad del siglo XX, desde ámbitos tan distintos como la sociología, la filosofía, el periodismo, el cine o la misma psiquiatría, se han criticado y cuestionado los saberes y las prácticas llevadas a cabo por los psiquiatras y psicoanalistas, poniendo especial énfasis en la función y gestión de las instituciones mentales. En este apartado queremos ver cómo el cine se ha apropiado de este pensamiento crítico y reformista, y ha contribuido a divulgarlo de forma más o menos acertada. Así mismo, pretendemos esbozar un marco conceptual donde inscribir la relación de João César Monteiro con toda 
esa amplia y compleja temática.

Erving Goffman, sociólogo integrante de la segunda escuela de Chicago, a mediados de los años cincuenta realizó una serie de estudios dedicados a los internados. Hospicios, hospitales, cárceles, campos de trabajo y concentración, cuarteles, barcos, escuelas de internos, abadías, monasterios y conventos forman parte, a distintos niveles, de lo que llamó instituciones totales, cuya característica central es que dentro de ellas se desarrollan todos los ámbitos de la vida bajo la supervisón de una única autoridad (Goffman, 2009, p. 21). Realizó sus investigaciones en el Hospital St. Elisabeth de Washington, que era una institución de prestigio de la época. Sus estudios evidenciaron que los asilos psiquiátricos eran, junto con los penitenciarios, los que integraban las estructuras más rígidas y controladoras (es cierto que muchos de ellos también ejercían una función carcelaria, pero aun así no era pretexto para que en ciertos casos pudieran llegar a ser sumamente represivos y violentos). Después de la segunda guerra mundial se empezó a poner de relieve la desposesión de los derechos de los "alienados", a la vez que se denunciaron las terribles condiciones a las que muchos de ellos estaban sometidos. No es de extrañar que esto sucediera, pues durante el inicio del s. XX los abusos habían ido en aumento. Ejemplos relevantes los podemos encontrar en los programas de esterilización obligatoria implementados durante los años cuarenta en la mayoría de estados norteamericanos (Scull, 2013. pp. 95-98). Se trataba de prácticas que conocieron su vertiente más inhumana con el régimen nazi, durante cuyo mandato se puso en marcha el "Programa T-4" exterminando a entre 200.000 y 250.000 pacientes en menos de cinco años. Se podrían añadir, también, las polémicas lobotomías promovidas por el premio Nobel Edgar Moniz y los psiquiatras americanos Walter Freeman y James Watts, que pasaron de ser un sistema de curación novedoso y aceptado a ser consideradas, en diez años, como prácticas inhumanas. Es pues justamente después del conflicto bélico cuando surgen algunos discursos importantes que intentan dar visibilidad a la imagen del alienado y, también de pasada, desestabilizar la psiquiatría. En Francia, Michel Foucault publicó su polémico libro La historia de la locura en la época clásica (1964), donde mostró la imagen de la locura que se había forjado durante los siglos XVII y XVIII. Destacó, entre otras cosas, que los dispositivos de poder —a partir de una concepción científica- 
originan las representaciones y los discursos de la enfermedad y la locura. Con ellos se legitiman mecanismos, diagnósticos e instituciones que pueden acabar siendo destinadas al control, la coerción y la segregación del sujeto. Es decir, este aparato permitía que el individuo no solo sufriera las dolencias provocadas por su desorden cerebral, sino que además se viera perjudicado por unas biopolíticas que lo sometían a un estado de excepción — reglamentado por poderes constituyentesque vulneraba y ponía en suspensión todos sus derechos básicos. Foucault localizaba el origen represivo de la locura y su posterior institucionalización en el siglo XVII, lo que dejaba entrever una dura crítica al racionalismo y, por extensión, al inicio de la era moderna. Según este autor, la sociedad disciplinaria surgía bajo la promesa de libertad del racionalismo, y con ello, siguiendo a Nietzsche, instauraba la duda dentro del proyecto del Siglo de las Luces. De forma colateral, esta crítica al racionalismo implicaba cierta visión idealizada de la vida en la época premoderna. Con todo, las tesis de Foucault supusieron un golpe fatal al saber psiquiátrico moderno con la denuncia de las ilusiones del humanismo y la noción de "progreso" (Roudinesco, 1993, p. 109). La celebridad que con el tiempo fue ganando el filósofo e historiador francés, hizo que sus ideas se consolidasen en la conciencia de la sociedad, pero también alentó a otros estudiosos a contrastar y verificar las fuentes en las que se basó. Los resultados obtenidos por algunos de ellos no fueron los imaginados, pues alertaban de que muchas de las referencias utilizadas eran desfasadas, incompletas o erróneas, concluyendo que las afirmaciones de Foucault eran en buena medida exageradas, e incluso, descabelladas (Scull, 2008), además de simplistas y generalizadoras (Porter, 2002, p. 97). Muchas críticas se han centrado en cómo Foucault proyectaba una atractiva imagen de la figura del loco, argumentada en el poder creativo inherente de la irracionalidad. Se ha visto al filosofo francés como uno más dentro de una corriente, cada vez más frecuente en Occidente, que ensalzaba las virtudes de la locura, siguiendo unos criterios más fundados en la estética que en la ética. En este sentido, pese a su extensión creemos oportuno introducir la cita entera de Juan José Sebreli, puesto que resume perfectamente las principales objeciones al pensamiento foucaultiano: 
El romanticismo primero, y luego el surrealismo y los postestructuralistas, en especial Foucault, difundieron la idea de locura como un estado de plenitud. La influencia nietzscheana los llevaba a pensarla como un estado de plenitud, como la lucha de los instintos dionisíacos contra la opresión de la racionalidad apolínea. Por el contrario, ajeno a esas febriles teorizaciones, el loco vive atormentado por el miedo y por la angustia. Lejos de liberar sus instintos o representar una contestación a la sociedad establecida, el loco, al igual que el hombre primitivo, suele ser prisionero del sentimiento de culpa que deriva de la imaginaria violación de los tabúes. La locura es un sufrimiento tan intenso que clama por la curación y desautoriza su idealización. Los poetas y los filósofos, con su exaltación lírico-metafísica de la locura, fueron manipuladores de los sufrientes, más peligrosos que la psiquiatría que denunciaban. ${ }^{2}$

Después de las reivindicaciones del mayo del sesenta y ocho, las tendencias que negaban el modelo psiquiátrico vigente empezaron a cobrar relevancia dentro del panorama social. La principal fue la llamada antipsiquiatría, que agrupaba a psiquiatras y psicólogos de procedencias distintas que no siempre se mostraban a gusto bajo dicha etiqueta. Esta corriente, al igual que muchos de sus protagonistas, sigue siendo polémica y actualmente denostada, pero la repercusión social, sobre todo en los ámbitos de izquierdas, fue lo suficientemente importante como para que su influencia se viera en distintos ámbitos de la sociedad. Entre otras manifestaciones, se podrían mencionar proyectos artísticos que, partiendo de premisas que cuestionaban el proceder de los asilos psiquiátricos, contribuyeron de forma notable a la configuración de la imagen y la opinión pública de la psiquiatría. Los psiquiatras iniciadores provenían y operaban en varios lugares: en Inglaterra trabajaron David Cooper y Ronald D. Laing, en Italia Franco Basaglia y en Estados Unidos Thomas Szasz, pese que este último rehusaría su vinculación con el movimiento. Todos ellos desarrollaron experiencias que iban en contra de las concepciones psiquiátricas establecidas, del encierro de los enfermos mentales, de la medicación o de las relaciones de jerarquía entre médico y paciente. Los métodos poco ortodoxos que utilizaron dieron sus frutos en casos como el de 
Mary Barnes, que al parecer padecía una esquizofrenia incurable, y a la que Ronald D. Laing intentó, con éxito, devolver a la sociedad. El caso fue célebre porqué años después Barnes acabaría convirtiéndose en una pintora reconocida. Otros episodios parecidos, tal vez no tan llamativos, permitieron que estas ideas se expandieran por todo Occidente, socavando por enésima vez los cimientos de la ciencia psiquiátrica. Entre los logros que se les puede atribuir, cabría destacar el hecho de haber situado un debate, que permanecía invisible, en la esfera pública. Más allá de los aciertos y errores de todos estos autores, lo que queremos resaltar son las distintas maneras en que se pone en tela de juicio las parcelas de control, el poder y el abuso que se escondían en ciertas prácticas psiquiátricas y centros de internamiento. La incidencia de estas denuncias en la sociedad estuvo acompañada de un creciente interés del mundo del cine hacia la psiquiatría, sobre todo en la figura del loco y en la institución. El médico psiquiatra también fue tomando relevancia, en especial el psicoanalista al que Hollywood le confirió un atractivo glamour. Lo que nos interesa aquí es dibujar el contexto en el que se inserta una producción artística que gira en torno a estas temáticas y realidades. Queremos mencionar, ni que sea brevemente, algunas de las producciones cinematográficas que partieron de dichos presupuestos y contribuyeron, en parte, a la denuncia y rectificación de las prácticas médicas. También debe resaltarse que, en muchos casos, ayudaron a difundir tópicos y visiones poco apropiadas. Todo ello con la finalidad de ofrecer un marco que ayude a ubicar las similitudes y diferencias de la aproximación a la locura por parte de João César Monteiro.

Como hemos señalado el cine tuvo un papel significativo en el momento de ofrecer una imagen sórdida de las prácticas psiquiátricas. De hecho esto no era nada nuevo, pues los precedentes se remontan a la novela romántica del siglo XIX con títulos como Jane Eyre (1847) de Charlotte Brontë, las pinturas de Francisco Goya o las terribles historias surgidas del hospital de Bethlem (Londres). Las críticas que se leían en las películas, estuvieran más o menos fundamentadas, jugaron un importante papel en la construcción de un imaginario estético, que situaría la locura y su gestión en un plano propio del cine de terror. Además, hay que tener en cuenta que buena parte de las producciones que provenían de Hollywood estaban muy influenciadas por el 
psicoanálisis freudiano, que durante buena parte del s. XX tuvo mucha aceptación en los Estados Unidos, lo que confería una visión muy concreta sobre los procedimientos psiquiátricos que se alejaban de la psicología dinámica. En muchos casos los argumentos cinematográficos se centraban en el análisis del inconsciente del enfermo, fuera este víctima o agresor, buscando en él las causas de su comportamiento y posibles traumas. También se dibujaban, no obstante, las instituciones psiquiátricas como lugares de coerción en las que una vez se había entrado era casi imposible salir. Son muchas las películas que abordan el tema de la locura y su confinamiento, y que principalmente se pueden dividir en dos grupos: las que presentan al enfermo mental recurriendo a tópicos para así ponerlos al servicio del guión; y aquellas que, comprometidas con el problema, han intentando contribuir con sus críticas, para así repercutir en la revaloración de la condición del enfermo dentro del tejido social. De las películas producidas en Hollywood que podríamos situar en el primer grupo destacamos Bedlam (1946) de Mark Robson, Psicosis (1960) de Alfred Hitchcock o la reciente Shutter Island (2010) de Martin Scorsese. En el segundo grupo entrarían producciones como The Snake pit (1941) de Anatole Litvak, Suddenly, Last Summer (1959) de Joseph L. Mankiewicz, Shock Corridor (1963) de Samuel Fuller o One Flew Over the Cuckoo's Nest (1975) de Milos Forman. Es interesante releer lo que el propio Monteiro escribió de Suddenly, Last Summer: "O mundo de Mankiewicz é um mundo de loucura ou de vítimas suas. Mas a loucura existe. Existe quotidianamente na desagregação do homem de hoje. A presença de manhã não é para nós; nem a de uns deuses dourados..." (Monteiro, 2005 , p. 80). Las películas mencionadas y muchas más colaboraron, en mayor o menor medida, en la construcción de la imagen del sujeto alienado en los hospitales, así como en divulgar una visión del médico psiquiatra, conservador y tradicional, capaz de reducir la personalidad de sus pacientes a las exigencias de la sociedad (Solà, 2006, p. 39). Una vertiente mucho más radical y realista fue proporcionada por documentales como Titicut Follies (1967) de Frederick Wiseman, o San Clemente (1980) y Urgences (1987) de Raymond Depardon. Estas películas son claros ejemplos de cómo se puede poner el dedo en la llaga mostrando abusos y las pésimas condiciones a las que eran sometidos los internados. El crudo realismo en que fueron filmadas daba 
muestras sobrecogedoras, verdaderamente difíciles de ignorar.

Las películas nombradas son algunos ejemplos del amplio catálogo cinematográfico de la relación entre cine y psiquiatría. Son producciones internacionales que gracias a su gran difusión e impacto social permiten dibujar un contexto conceptual o temático. El cine de Monteiro se podría inscribir en este debate, si bien formal y estilísticamente configura unas directrices propias. Mucho más cerca quedaría la película Jaime (1974) de António Reis, tal vez el precedente más claro dentro del cine portugués y de la cual Monteiro escribió una crítica en la que la definía como:

um dos mais belos filmes da historia do cinema ou, se preferem: una etapa decisiva e original do cinema moderno, obrigatório ponto de passagem para quem, neste ou noutro país, quiser continuar a prática de um certo cinema, o cinema que só tolera e reconhece a sua própria austera e radical intransigência. ${ }^{3}$

Jaime es un medio metraje dedicado a la vida de Jaime Fernandes, campesino que a los treinta y ocho años fue internado en el hospital Miguel Bombarda, donde fallecería a la edad de sesenta y nueve años. Durante su vida en el hospital, y una vez cumplidos los sesenta años, empezó a realizar una serie de dibujos y escritos que lo convirtieron en una figura clave del arte alienado portugués. La película fue rodada en ese famoso edificio, el mismo donde Monteiro filmaría Recordações da casa amarela (1989). Ese centro psiquiátrico es célebre por su pabellón de seguridad en forma de panóptico, diseñado por José María Nepomuceno siguiendo las coordenadas de Jeremy Bentham: un modelo no sólo de prisión sino también pensado para cualquier tipo de institución total, un mecanismo para que el poder de la institución cobre máxima fuerza, "un esquema formal para la constitución de un poder individualizador y un saber sobre los individuos" (Foucault, 2005, p. 89). Cabe decir que, hoy en día, el Hospital Miguel Bombarda ha perdido su función originaria y se ha convertido en un museo que exhibe la historia de la institución y una colección de arte outsider.

La película de Reis es de corte experimental y, por la manera de 
presentar el espacio psiquiátrico y a sus habitantes, podemos decir que también es de denuncia. Es preciso hacer notar el carácter onírico de todo el filme, tanto por sus imágenes sumamente enigmáticas, como por los dibujos y textos de Jaime Fernandes, o por la inquietante música de Stockhausen que de vez en cuando ocupa el espacio sonoro (como se verá Monteiro recurrirá a las partituras de este compositor en algunas de sus películas). Así mismo queremos resaltar un detalle singular: hacia la mitad del metraje hay un plano, fotografiado en un acentuado claroscuro, donde se puede ver un paraguas abierto en medio de una sala. Esta misma composición y posición del paraguas la encontramos en la escena de Le bassin de J. W. (1997) de Monteiro, en la que João de Deus se halla escondido debajo del paraguas en frente del puerto marítimo. Las dos escenas guardan evidentes parecidos formales y compositivos, pese a que la de Reis es sombría y la de Monteiro cuenta con la radiante luz de Lisboa. Se puede medir el efecto que le causó la cinta si se tiene en cuenta que Monteiro aún tenía la película en la cabeza veinte y tres años después de haberla visto.

\section{Cerrar fisuras}

Hasta el momento hemos expuesto algún aspecto biográfico que relaciona la vida de Monteiro con la locura. Hemos intentado también ofrecer un breve repaso a los episodios más destacados de la historia reciente de la psiquiatría y mostrar de qué manera el cine se ha ocupado de ellos. Pasemos ahora a analizar las películas de Monteiro que más explícitamente abordan la temática de la locura, para ver cómo - lejos de querer construir una visión general - Monteiro utiliza la alienación mental con la finalidad de exhibir actitudes y opiniones que de otra manera no hubieran sido posibles, sin asumir riesgos personales.

Quem espera por sapatos de difunto morre descalzo (1972) fue la segunda película de Monteiro, pero la primera en la que aparecían elementos autobiográficos. Este medio metraje se rodó en 1970, justo después de haber salido del internamiento psiquiátrico. El filme empieza con las secuencias de una película antigua de 1965, que había sido parte de un proyecto frustrado por falta de dinero. En la cinta aparece su expareja, cuya relación con ella desencadenó las crisis que llevaría al 
director a la reclusión psiquiátrica e incluso a recibir un electroshock. La recuperación de la cinta significa algo más que una revisión de un pasado cercano, parece más bien un intento de suturar heridas emocionales. Quem espera es una nueva escenificación del proyecto truncado. El personaje principal, Lívio, primer álter ego de Monteiro, es interpretado por Luís Miguel Cintra, pero doblado por Monteiro; y Paula Ferreira interpreta el papel de Mónica. Cuando empieza la verdadera película, después de los créditos, el negro inunda toda la sala con música de Anton Webern. Seguidamente empieza el drama, que a partir de un guión sumamente críptico repasa diferentes momentos autobiográficos. Es muy interesante la escena que reproduce milimétricamente la antigua discusión entre los dos amantes, la original era muda, pero la actual cuenta con un diálogo que acaba con estas palabras: "Mónica, Mónica, Mónica/ não me abandones/ disse ainda o fantasma antes de/ a luz o absorver/ completamente/ quem, a não ser vida/ tem o dom de tocar a vida?" donde se aprecia la importancia de la luz para describir los estados anímicos. La escena termina con el álter ego de Monteiro cubriéndose la cara con las manos, en sentido de desesperación. La fotografía se quema gradualmente virando al blanco con la consiguiente entrada de la música. Es importante señalar que tanto la presentación en negro, los virajes al blanco (luz), como el plano final fijo de un minuto y medio de la cara del actor son claros precedentes de los planteamientos que treinta años después se verán en Branca de Neve (2000).

El siguiente filme fue Fragmentos de un Filme-Esmolal A sagrada família rodado entre 1972 y 1973, pero en el que siguió trabajando durante los cuatro años siguientes. En esta película de carácter experimental —que cuenta con textos de James Joyce, André Breton, Esquilo y Francis Ponge; y la música de Mozart y Stockhausenabundan las referencias a la locura. En la primera escena de la película y a modo de presentación, aparece Monteiro levantando el dedo medio de la mano, haciendo la peineta a la cámara. Este gesto puede entenderse como una declaración de principios y como un preludio de lo que a continuación va a seguir. El personaje principal, João Lucas, interpretado por João Perry, es otro álter ego de Monteiro, las escenas donde aparece se pueden dividir en dos tipos: aquellas en las que está en la cama y aquellas otras en las que está en cuclillas encima de una mesa 
luciendo una careta de cerdo. En las primeras se ven diferentes acciones que van desde lamentos angustiosos a escenas amorosas y de coito con su pareja, pasando por juegos infantiles con su hija. La segunda tipología, que de hecho es un largo plano secuencia de más de diez minutos, es en nuestra opinión el nudo de la película, a parte de ser una de las escenas más perturbadoras de toda la producción de Monteiro. En ella se muestra la discusión entre dos parejas: João Lucas y su mujer, y los padres de ella. Mientras los cuatro hablan la hija del matrimonio va entrando y saliendo del plano con una cámara en la mano en acción de grabar. La postura de João Lucas destruye la lógica de una conversación familiar, de hecho funciona a modo de revulsivo de toda norma social. Mientras la hija permanece casi callada y la abuela muestra una actitud conciliadora, el abuelo, que es el único que se percata de la provocación, lo reprueba constantemente, hasta llegar a compararlo con un australopiteco y a decir que está loco. Estas últimas palabras rompen el silencio de João Lucas y salta de forma violenta encima del anciano, que termina por echarlo de la casa. Aunque sea una mera suposición no deja de ser factible hacer una analogía entre los arrebatos y la actitud del personaje ficticio con la del propio director.

Hay rastros de locura en el diálogo que parte de un texto de Breton, cuando el personaje declama a su mujer que "desea que sea locamente amada", poco después ella le dispara y terminan los dos muertos tendidos en la cama. Una vez más se repite la tragedia entre dos amantes (téngase en cuenta lo reciente que aún estaba el episodio del internamiento de Monteiro). Otra referencia, quizás más sutil, es el tema musical de Stockhausen, dedicado al color rojo que suena mientras la mujer de João Lucas baila en estado de trance. El contraste de los coros que repiten, en distintos idiomas, la palabra rojo con la imagen en blanco y negro iluminada con un flash intermitente, crea una imagen visual alucinatoria y sumamente onírica.

\section{El oficial aristocrático}

Recordações da casa amarela (1989) es la primera película de la trilogía de João de Deus. El póster promocional incluye una pintura de George Grosz titulada Johann der Frauenmörden (1918) —la 
traducción literal sería Johann el asesino de mujeres - y en ella se puede ver a un hombre cabizbajo vestido de negro huyendo y dejando atrás el cuerpo mutilado de una mujer desnuda. Esta pintura encaja perfectamente con el contenido y la forma de la película, tanto es así que se puede llegar a identificar el personaje pintado con el interpretado por Monteiro. La película está rodada a modo de comedia sórdida. Empieza con un significativo texto escrito sobre pantalla negra: "Na minha terra chamavam casa amarela à casa onde guardavam os presos, por vezes, quando brincávamos na rua, nós, crianças. Lançávamos olhares furtivos para as grandes grades escuras e silenciosas das janelas altas e, com o coração apertado, balbuciávamos: «coitadinhos!...»". La casa amarilla no es precisamente una cárcel, sino un manicomio (Da Costa, 2004, p. 384), lugar donde habita João de Deus. En ella se desarrolla un periplo vital que se inicia con el reconocimiento de ciertas dolencias testiculares y deriva en delirios que lo llevarán a perpetrar una violación y finalmente a ser internado en el asilo Miguel Bombarda. Son muchos los aspectos que se cruzan en el camino: la religión, el sexo claramente identificado con el clarinete de la bella Julieta (Teresa Calado), los fetiches vouyerísticos, y finalmente la identificación con un oficial de caballería portugués, que no tarda en calificar de aristocrático. Esta identificación se basa en el teniente de la caballería austriaca Erich von Steuben, protagonista de la película Blind Husbands (1919), dirigida por Erich von Stroheim que, al igual que Monteiro, se pondrá en la piel del militar. El teniente von Steuben es un dandi mujeriego, algo mezquino, que intenta seducir a una mujer casada. El personaje hace gala de porte militar, presumiendo durante toda la película para dar al final muestras de mezquindad y cobardía. João de Deus tiene su fotografía colgada en la pared de su habitación, y en el preciso momento que, hacia la mitad de la película, la cámara enfoca el retrato, es cuando enloquece, viola a la chica, se viste de militar y se adentra en la locura. Es significativo que cuando João de Deus es registrado en la comisaría, uno de los objetos que se le requisan es una edición de la tragedia La muerte de Empédocles de Friedrich Hölderlin, poeta que pasó buena parte de su vida afectado por trastornos mentales.

También es notable la presencia de la madre en una de las secuencias. João de Deus hace una breve y fría visita a su madre, a la que encuentra fregando el suelo de la escalera, para pedirle algo de dinero. La escena 
es relevante porque da pistas de lo que pudiera haber sido la relación con su madre verdadera, es decir distante. En el escrito autobiográfico $A$ minha certidão, Monteiro relata la muerte de su padre y algunos aspectos de su carácter: "Tendo finalmente conseguido dissipar toda a fortuna na satisfação de brutais apetites, o meu garboso pai veio a falecer vitimado por cruel ataque cardíaco, deixando-me, perplexo e sem um chave, a coçar a cabeça." (Monteiro, 2005, p.57). El texto parece poco fiable, pues alguna fuentes próximas al director contradicen lo dicho e insinúan que en realidad no falleció por un ataque al corazón sino por suicidio (Da Silva, 2004, p. 64). De su madre casi no existen referencias escritas, tan solo podemos reconstruir su imagen a partir de las tres veces que aparece en sus películas: en Fragmentos de un FilmeEsmola (1972), en Recordações da casa amarela y en Vai e vem (2002). Como se verá un poco más adelante, la figura materna se volverá a plantear en Branca de neve (2000), puesto que esta sí que fue una pieza clave en la vida de Robert Walser y, en el poema dramatizado, la relación entre hija y madrastra es el eje vertebral de la historia. Las relaciones entre madre e hijo permitirían hacer especulaciones desde el ámbito del psicoanálisis, entendemos, no obstante, que las lecturas que ofrecen tanto los filmes de Monteiro como los de Walser son suficientemente sugerentes como para que no queden restringidas a este ámbito. Léase su mención solo desde un punto de vista referencial, puesto que un análisis en profundidad escapa a las intenciones de este artículo.

João César Monteiro, en Recordações da casa amarela (1989), se refiere explícitamente al mundo de la locura: los delirios, la extravagancia y el despliegue de un comportamiento fuera de lo habitual son la norma. En muchas de sus películas él mismo encarna a diversos personajes que, a modo de dobles, le sirven para presentarse en estado de embriaguez, enfermo mental, mostrar su lado perverso e incluso la enfermedad terminal. En una entrevista realizada dos años después del rodaje de Recordações, explicaba de la siguiente manera cómo entendía los personajes que encarnaba: "Não é uma autobiografia no sentido exacto do termo. Penso que a personagem é uma espécie de duplo da minha pessoa. Um duplo um tanto ou quanto exagerado, tratado de uma forma hiperbólica" (Monteiro; Gili, 2004, p. 411). Desde este punto de vista destaca la escena rodada en el hospital Miguel Bombarda. Es 
justamente allí donde João de Deus encuentra a Lívio (Luis Miguel Cintra) primer álter ego aparecido en Quem Espera por sapatos de difunto morre descalzo. Este encuentro permite trasladar el problema del doble, hasta ahora situado entre la realidad del director y la ficción encarnada por actores; para pasar a ser una superposición de personalidades que remiten a una misma figura, es decir, a João César Monteiro, y así enlazar tiempos y espacios distintos. El lugar donde esto sucede es un hospital psiquiátrico; el doble, una especie de miraje especular, surge de la irracionalidad cercada. Con este guiño temporal, Monteiro consigue trenzar sus películas convirtiéndolas en un continuo temático, donde las referencias y citas se entrecruzan para construir a partir de fragmentos algo similar a lo que es una experiencia vital. El cine se constituye como un poliedro de significados.

\section{El cine invisible}

El ciclo de João de Deus empieza con Recordações, y pese que estrictamente conforma una trilogía junto con $A$ comédia de Deus (1995) y As Bodas de Deus (1998), se podría decir que todas las demás películas realizadas a partir de 1989 constituyen un cuerpo unitario coherente. Nos referimos a O Último Mergulho (1992), Le Bassin de J. $W$. (1997), Branca de Neve (2000) y Vai e Vem (2002), a la que, como se ha visto, se podría añadir Quem Espera por sapatos de difunto morre descalzo (1972), Fragmentos de un Filme-Esmolal A sagrada família (1972) y prácticamente todos los cortos rodados a partir de 1989. La razón radica en el hecho de que todas estas películas son distintas maneras de elaborar autorretratos, mediante dobles y álter ego. Si bien la bohemia y las irreverencias están presentes en todo el ciclo - especialmente en Le Bassin de J. W., rodada e interpretada en estado de embriaguez-, la locura no es el leitmotiv principal de todas ellas. El sexo y sus desviaciones son los aspectos más subversivos que aparecen en $O$ Último Mergulho, As Bodas de Deus y A comédia de Deus, pudiéndose ofrecer una visión perversa e irracional de su tratamiento. Por otro lado Vai e Vem explora el lado más intimista y reflexivo del autor. No hemos querido detenernos en el análisis de dichos filmes, puesto que entendemos que el enfoque de este trabajo se dispersaría 
demasiado. Branca de Neve es, sin duda, un caso distinto que apela directamente a los estados mentales. De todo este ciclo es la obra más críptica e inaccesible, y en la que el hecho autorreferencial es menos visible, excepto en la escena final, cosa que la convierte en una peculiaridad dentro del conjunto.

Schneewittchen (1902) es un poema dramatizado de juventud de Robert Walser, que continúa el cuento clásico de los hermanos Grimm allí donde ellos lo habían dejado. La historia empieza cuando Blancanieves rechaza casarse con el príncipe e intenta reconciliarse con su madrastra que, contradiciendo la versión de los Grimm, no está muerta. Publicado originariamente en 1902 en la revista Dies Insel, el texto fue incluido en una selección de poemas de 1909 con el título Gedichte, editada por Bruno Cassirer. Walter Benjamin veía en el poema un ejemplo de cómo se formulaba el proceso de curación de unos personajes "que llevan y tienen tras de sí la locura"; de él dijo que era "una de las obras más profundas de la literatura reciente" (Benjamin, 2010, pp. 333-334). La adaptación del texto por parte de Monteiro fue concebida como una acción radical que acabó transformándose en una experiencia que va más allá de lo puramente cinematográfico, ofreciendo un resultado sin equivalentes en el mundo del cine. Una acción fílmica que parte de la negación de proyectar imágenes, es decir, de iluminar la pantalla, y que expone un texto que reconcilia a unos personajes antagónicos.

Branca de Neve invita a hacer una lectura que tenga en cuenta las circunstancias vitales de Monteiro. La película se enmarca en una situación de crisis creativa, manifestada en un encadenamiento de escollos que imposibilitan llevar a término los proyectos ideados. Los excesos que habían protagonizado el rodaje de Le Basin de J. W. en forma de repetidos episodios de mal genio y embriaguez, se convierten aquí en impotencia. En un principio se planeó una adaptación de $L a$ Philosophie dans le boudoir ou les instituteurs immoraux (1795) del marqués de Sade, obra en forma de diálogos que, como en Schneewittchen de Walser, tiene en la relación entre madre e hija el elemento central. Sade es una figura muy presente en el ciclo de João de Deus, ya sea por su carácter erótico y perverso, ya sea porque se le cita directamente. De hecho Sade, junto con Strindberg y Céline, es una de sus principales influencias. Se puede afirmar que Branca de neve (2000) 
surge de la impotencia de filmar la obra del marqués. La solución a esta renuncia es adaptar el poema dramatizado de Walser, en el que se desarrollan algunos temas paralelos de manera menos cruel, pero más sensual y poética. En medio del rodaje de Branca de Neve, Monteiro empezó a plantear preguntas en torno al sentido y la función de las imágenes. Los resultados que estaba obteniendo no le gustaban, así como tampoco le satisfacía la actuación de los actores ni la propia idea de la que partía. El poema era extraordinario y su puesta en escena mediante imágenes en movimiento no iba a funcionar (Barroso, 2000). Dado que no quería hacer una ilustración decidió suprimir la imagen; de los actores solo permanecerían las voces, el cine quedaría a oscuras. Según contó él mismo en una entrevista fue después de pasar una noche en velo que acordó con el director de fotografía hacerlo de esta forma (Monteiro, 2000). Resulta curioso la manera como escenificó la obra, el primer paso fue registrar todos los diálogos en portugués, sin filmar; seguidamente los actores, que eran franceses, representaron la obra mediante la sincronía de labios. Este método hace que la banda sonora resultante sea una especie de simulacro en la que, mediante el montaje, se unen dos tiempos distintos: las palabras y el sonido ambiental. La drástica decisión de eliminar la imagen, parte, sin duda, de una serie de reflexiones estéticas radicales en torno a qué es y cómo se debe abordar la adaptación de una obra literaria al cine, pero cabe recordar también que surge de una situación personal complicada. Monteiro no intenta disimular su impotencia, de hecho mientras rodaba él mismo decía que no sabía nada sobre cine y que no se sentía capaz de hacerlo (Tavares, 2004, p. 87). La opción por la que se decantó fue la de dejar la pantalla en negro, obviando los desajustes en los costes de producción subvencionados por el Estado, lo que generó una auténtica polémica en Portugal. Tal y como se puede ver en un documento filmado durante la presentación de la película, cuando fue preguntado al respecto, sus respuestas fueron "puta que os pariu" y "quer que o público se foda", alimentando la fama de director intratable y subversivo. Parece como si Monteiro estuviera sujeto en una dicotomía: Branca de neve era un producto rompedor y de gran densidad intelectual, pero este había surgido de un estado emocional complejo fruto de reiteradas sensaciones de fracaso.

Como se ha dicho, Monteiro sitúa al espectador en un espacio oscuro 
ocupado por voces. Este actúa como una especie de caja de resonancia donde los diálogos en verso llenan el lugar de imágenes verbales que remiten a la nieve, concretamente al color blanco. En este sentido, la inclusión de las fotografías de Walser muerto, yaciendo sobre la nieve, toma un valor metafórico que actúa como bisagra entre la vida y la muerte. Otros espacios de tránsito se darían entre el fin del relato de los Grimm y el inicio del de Walser, y el paso del mundo visible de la imagen luz (proyectada) al de la oscuridad del texto. El odio, el amor, la traición, el perdón y la reconciliación son algunos de los temas que se van entrelazando entre la musicalidad del recitar y la presencia fantasmal de los personajes. El espectador queda sumergido en un lugar sin luz, donde la palabra es la única fuente de visibilidad; una visón que remite a imágenes idealizadas formadas gracias al influjo del verbo. Las voces resuenan por toda la sala y lo hacen de forma sensual. La poesía circunscrita al espacio cerrado y oscuro, se convierte en una analogía de la voz mental.

Existen en el cine experimental o el vídeo arte algunos antecedentes que pueden ayudarnos a ubicar la obra de Monteiro. No es seguro que él tuviera conocimiento de ellos, pero sí habían sido claros precedentes en la revisión de los lenguajes cinematográficos, ya sea desde el arte o el cine. Estas propuestas dan cobertura a proyectos que, como el suyo, rozan los límites de las disciplinas. Una pieza temprana es Wochenende (1930) del director alemán Walter Ruttmann. Esta película de once minutos y diez segundos, que se anticipó a la música concreta, deja la pantalla en negro para dar lugar a un collage sonoro que emplea sonidos del paisaje urbano. Otro precedente podría ser Arnulf Rainer (19581960) de Peter Kubelka, cinta de seis minutos y veinte y cuatro segundos elaborada mediante la interacción de fotogramas transparentes y opacos, a lo que se le sumaba un sonido hiriente que simulaba el paso de la luz a la oscuridad. La película sometía al espectador a una experiencia extrema de fotosensibilidad que en ciertos casos podían producir ataques epilépticos. En ella se recurre a diferentes efectos que podrían devenir torturas audiovisuales y sonoras, de hecho un espectador corriente solo la puede tolerar debido a su corta duración. Diez años más tarde, Kubelka planteó otra pieza similar, A propos Film (Invisible Cinema) (1970), que consistiría en dejar una sala de cine completamente a oscuras en la que sólo hubiera sonido. Las dos 
propuestas de Kubelka inciden en un aspecto común con Branca de neve; nos referimos a que se sale de los parámetros de la representación visual normativa con el objetivo de situar en primer término el espacio de proyección (Windhausen, 2003, p. 13). En un plano diferente estaría Blue (1993) de Derek Jarman, película rodada poco antes de su muerte, donde un azul intenso ocupa toda la pantalla y en la que se narran aspectos íntimos de la vida y el pensamiento del director. Estas propuestas situadas en el límite del cine permiten asegurar un contexto intelectual y de diálogo con la obra de Monteiro, al mismo tiempo que alejarla de cualquier suposición acerca del carácter extravagante o provocativo del director. Es posible que la decisión de dejar a oscuras al espectador no parta solo de planteamientos puramente estéticos, pues hay que tener en consideración el efecto psicológico producido por el negro y los breves incisos de luz, que actúan como descargas que dilatan las pupilas y ciegan la vista. En la estructura de Branca de neve se pueden ver aspectos de todas las películas antes mencionadas, pero toma distancia por el hecho de que en ella la sensualidad coge protagonismo. No se puede decir que Monteiro utilice la oscuridad para violentar al espectador, entendemos que aquí su uso es más introspectivo y, por qué no decirlo, afectado. Pensemos en la melancolía, el propio nombre esta compuesto de dos raíces latinas que son melan y chole que significan negro y bilis respectivamente, es decir, un ánimo negro para denominar estados depresivos (Scull, 2013, p. 30). Siguiendo esta senda, no es difícil intuir que la decisión de eliminar la luz de la sala no esté del todo desligada del hecho de reproducir los efectos o estados anímicos del propio autor.

El planteamiento de Monteiro parte de un aspecto mucho más ligado a la poesía y a la literatura. Con el recitar de la poesía se construyen imágenes, que se tornan visibles en nuestras mentes como si fueran ensoñaciones o alucinaciones. Son voces, quizás, parecidas a las que oía Walser en sus sueños, tal como él mismo relata: "en los últimos años de Berna me atormentaban desordenados sueños: truenos, gritos, manos que me estrangulaban, voces alucinadas, de tal modo que a menudo me despertaba gritando" (Seeling, 2000, p. 23). Tales experiencias llevaron al escritor a realizar un frustrado intento de suicido y, siguiendo los consejos de su hermana Lisa, a visitar al doctor Walter Morgenthaler - el mismo que unos años antes había tratado a su hermano Ernst- que 
al encontrarlo deprimido y afectado decidió internarlo en Waldau. Tan solo entrar en el asilo le fue diagnosticada esquizofrenia, a causa de su deteriorado estado $\mathrm{y}$, también, del historial de sus antecedentes familiares (Sauvat, 2002, p. 212). En la película de Monteiro se entrecruzan el negro con el blanco. La vista se hunde en la oscuridad, mientras que con la mente nos adentramos en blancos y fríos parajes. La nieve tiene una función dual parecida a la que se detecta en la obra de Walser. El paisaje blanco fue motivo de inspiración y referencia tanto en sus escritos como en su vida, tal y como lo atestigua su amigo Carl Seeling:

durante el cumpleaños, empezó a nevar suavemente. Cuando la esposa del Dr. Steiner habló a sus hijos de las bellas páginas que Robert Walser había escrito sobre el invierno, la nieve y el frío, dijeron que sin duda nevaba porque al señor Walser le gustaba tanto el invierno, y hoy era su cumpleaños. ${ }^{4}$

Fue, no obstante, también en la nieve donde lo encontraron tendido y muerto. Blancanieves ya advirtió que la nieve no soportaba la luz del sol "Soy callada/ como nieve blanda al sol./ Nieve soy, y con el cálido/ aliento de primavera,/ que no es mío, me derrito./ Lenta fusión. ¡Tierra mía,/ acógeme en tu morada!/ Estar al sol me hace daño." (Walser 1997, p. 73). La luz y la oscuridad cumplen en la nieve una premonitoria metáfora en torno a la vida. Las preguntas que se hacía el poeta cobran relevancia "¿Acaso la vida humana está siempre llena de sol? ¿No son sólo la luz y las sombras las que le dan sentido?" (Seeling, 2002, p. 37). Monteiro escenifica esta dualidad e invita a la reflexión y a la poesía, en la que el paso de lo conocido a lo desconocido se da mediante el tránsito de luz y de oscuridad. Al final de la película la luz regresa con la figura de Monteiro, el director habla a la cámara pero el sonido está ausente. Un zoom lento amplia su rostro hasta que el ojo ocupa toda la pantalla. Una aparición que se vincula con la primera escena de Fragmentos de un Filme-Esmolal A sagrada familia, a modo de firma, de acto de presencia. Branca de Neve quizás sea la película que mejor define una postura que se siente incómoda dentro de las convenciones, pero que a la vez es extremadamente sensible a todo aquello que la rodea. 
Monteiro, pese a la fama, fue según contaba la actriz Claúdia Teixeira una persona hipersensible, dada a los excesos pero también extremadamente dulce y benévola (Teixeira, 2004, p. 151). Lo mismo sucede en su obra en la que el juego entre lo racional y lo irracional sirve para elaborar un complejo autorretrato, que es a la vez concreto y escurridizo.

\section{Conclusión}

João César Monteiro fue, sin duda alguna, una figura singular no solo dentro del cine portugués, sino de la escena europea. Como se ha visto, algunos episodios personales, juntamente con las imágenes que proyectan los álter ego que circulan por sus películas, refuerzan la idea de que situó tanto su vida como su obra al límite. De su afinidad con autores como Strindberg, Rimbaud, Céline o Pasolini heredó un carácter anárquico e individualista que lo llevaría a continuos enfrentamientos con los representantes de la cultura de su país. Monteiro colocaba a sus álter ego en posiciones extremas en las que la cordura parecía no existir. Pero a diferencia de otros cineastas, no utilizó la demencia de manera romántica o escabrosa, ni tampoco quiso elaborar una crítica sobre las circunstancias de la psiquiatría y sus pacientes. Para Monteiro la locura fue una coartada para expresar aquello que desde la normalidad no era posible. Su cuerpo y su voz, seguramente los rasgos más característicos de su cine, fueron las herramientas. Los álter ego —Lívio, João Lucas, João de Deus, senhor Eloi, Jean de Dieu o João Vuvu — no son roles neutros, se imponen a la pantalla y al espectador; sus pasiones y perversiones toman protagonismo a modo de exposición psicológica. Creemos que las palabras que le dedicó Manoel de Oliveira describen perfectamente la ambivalente personalidad de Monteiro: él fue "um esquizofrénico controlado, raramente descontrolado", una esquizofrenia que afectaba "no seu modo de expressar os seus impulsos esquizofrénicos que agiam nele como se fora nele uma normalidade e assim essa naturalidade dada às imagens tornando-se normal em sua perfeita excentricidade" (Oliveira, 2005, p. 581). Monteiro muestra su figura vulnerable en situaciones adversas y comprometidas, aquellas que ponen en cuestión y en graves aprietos al sujeto, a su persona. Los 
procedimientos para hacerlo oscilaban entre el drama (sus primeros filmes), la comedia (Recordações da casa amarela) o la presentación más descarnada, donde el propio director se exhibía embriagado delante la cámara (Le basin de J. W.). Pero de todos ellos la formulación menos evidente pero sí más críptica (Branca de neve) es la que proporciona la información más sugerente, entretejida por el texto y el gesto poético, instala al espectador en el centro mismo del conflicto haciéndolo partícipe de un entorno preformativo.

\section{Agradecimientos}

Este artículo forma parte del proyecto ALST (referencia FFI2012-31024), financiado por el Ministerio de Economía y Competitividad.

\section{Notas}

1 Silva Tavares, Víctor (2005). Silva Tavares, p. 85.

2 Sebreli, J. J. (2007). El olvido de la razón. Un recorrido crítico por la filosofía contemporánea. pp. 325-326. Barcelona: Debate.

3 Monteiro, J. C. (2005). Jaime, o inesperado no cinema português. En Nicolau, J. (Ed.), João César Monteiro (p. 172). Lisboa: Cinemateca Portuguesa.

4 Seeling, 2002, p. 128.

\section{Referencias}

Barroso, M. (2000). Entrevista. En Monteiro, J. C., Branca de neve. (DVD). Lisboa: Lusomundo.

Benjamin, W. (2010). Robert Walser. En Benjamin, W., Obras. Libro II/vol. 1 (331-334). Madrid: Abada.

Da Costa, J. B. (2005). César Monteiro: Depois de deus. En Nicolau, J. (Ed.), João César Monteiro (pp. 381-404). Lisboa: Cinemateca Portuguesa.

Da Silva, P. (2004). Le buisson ardent. En Colin, L.; Da Silva, P.;

Larrosa, S.; Loiseau, S.; Py, A.; Uzal, M. (Eds.), Pour João César Monteiro «Contre Tous les feux, le feu, mon feu» (pp. 57-69). 


\section{Lieja: Yellow Now.}

Gili, J. A. (2005). Um cineasta na cidade (entrevista com João César

Monteiro). En Nicolau, J. (Ed.), João César Monteiro (pp. 410-

416). Lisboa: Cinemateca Portuguesa.

Gil, M. (2005). Propos recueillis à Lisbonne, en julliet 2003. En Colin,

L.; Da Silva, P.; Larrosa, S.; Loiseau, S.; Py, A.; Uzal, M. (Eds.),

Pour João César Monteiro "Contre Tous les feux, le feu, mon feu»

(pp. 95-106). Lieja: Yellow Now.

Foucault, M. (2005). El poder psiquiátrico. Madrid: Akal.

Goffman, E. (2009). Internados. Ensayos sobre la situación social de los enfermos sociales. Buenos Aires: Amorrortu.

Monteiro, J. C. (2005). Bruscamente no verão passado. En Nicolau, J. (Ed.), João César Monteiro (pp. 80-81). Lisboa: Cinemateca Portuguesa.

Monteiro, J. C. (2005). A minha certidão. En NICOLAU, J. (Ed.), João César Monteiro (pp. 57-59). Lisboa: Cinemateca Portuguesa.

Monteiro, J. C. (2005). Jaime, o inesperado no cinema português. En

Nicolau, J. (Ed.), João César Monteiro (pp. 171-189). Lisboa:

Cinemateca Portuguesa.

Monteiro, J. C. (2000). Entrevista a JCM. En Monteiro, J. C., Branca de neve. (DVD). Lisboa: Lusomundo.

Oliveira, M. (2005). César Monteiro. Cineasta deontologicamente exemplar. En Nicolau, J. (Ed.), João César Monteiro (pp. 581583). Lisboa: Cinemateca Portuguesa.

Porter, R. (2002). Breve historia de la locura. Madrid: Turner/Fondo de cultura económica.

Rocha, P. (2005). Propos recueillis à Porto, en juillet 2003. En Colin, L.; Da Silva, P.; Larrosa, S.; Loiseau, S.; Py, A.; Uzal, M. (Eds.), Pour João César Monteiro "Contre Tous les feux, le feu, mon feu» (pp. 107-112). Lieja: Yellow Now.

Roudinesco, E. (1993). La batalla de cien años. Historia del psicoanálisis en Francia. 3 (1925-1985). Madrid: Fundamentos.

Sauvat, C. (2002). Robert Walser. Mónaco: Éditions du Rocher.

Scull, A. (2008). "Los endebles cimientos del monumento foucaultiano": Revista de libros de la Fundación Caja Madrid, 135, 27-30.

http://www.jstor.org/discover/10.2307/30231100?uid=3737952\&u 


\section{$\mathrm{id}=2129 \&$ uid $=2 \&$ uid $=70 \&$ uid $=4 \&$ sid $=21102166487251$}

Scull, A. (2013). La locura. Una breve introducción. Madrid: Alianza. Sebreli, J. J. (2007). El olvido de la razón. Un recorrido crítico por la filosofía contemporánea. Barcelona: Debate.

Seeling, C. (2000). Paseos con Robert Walser. Madrid: Siruela.

Silva Tavares, V. (2004). Propos recueillis à Lisbonne, En Colin, L.; Da

Silva, P.; Larrosa, S.; Loiseau, S.; Py, A.; Uzal, M. (Eds.), Pour

João César Monteiro «Contre Tous les feux, le feu, mon feu» (pp.

71-93). Lieja: Yellow Now.

Solà. A. (2006). Hollywood. Cine y psiquiatría. Barcelona: Base.

Teixeira, C. (2004). Entretien réalisé à Lisbonne en juin 2003 par

Sandrine Loiseau et Aurélien Py. En Colin, L.; Da Silva, P.;

Larrosa, S.; Loiseau, S.; Py, A.; Uzal, M. (Eds.), Pour João César

Monteiro «Contre Tous les feux, le feu, mon feu» (pp. 145-153).

Lieja: Yellow Now.

Walser, R. (1997). Blancanieves (Comedia en verso 1902). En Walser,

R. Poemas. Blancanieves (pp. 57-112). Barcelona: Icaria Poesía.

Winhausen, F. (2013). Límits i possibilitats. En Miró, N. (ed.), Insomnia

(pp. 10-15). Barcelona: Fundació Joan Miró.

\section{Joaquim Cantalozella Planas es Profesor Agregado en el}

Departamento de Pintura de la Facultad de Bellas Artes de la Universitat de Barcelona. España.

Marta Negre Busó es Profesora Lectora en el Departamento de Pintura de la Facultad de Bellas Artes de la Universitat de Barcelona. España.

Contact Address: Facultad de Bellas Artes. Universitat de Barcelona. Departamento de Pintura. C/ Pau Gargallo, 4. 08028 Barcelona. España. E-mail address: jcantalozella@ub.edu, martanegre@ub.edu 
Instructions for authors, subscriptions and further details:

http://brac.hipatiapress.com

Conxita Boncompte, “Iconografia picassiana (1905-1907). Influencia de la pintura pompeiana".

Goya, núm. 335 (2011), pp. 156-179

Mireia Freixa ${ }^{1}$

1) Departamento de Historia del Arte, Facultad de Geografía e Historia. Universitat de Barcelona, España.

Date of publication: October, 3rd 2013

To cite this review: Freixa, M. (2013). Conxita Boncompte, "Iconografia picassiana (1905-1907). Influencia de la pintura pompeiana”. Goya, núm. 335 (2011), pp. 156-179. (Review of the doctoral thesis). Barcelona, Research, Art, Creation, 1(2), 228-230. doi: 10.4471/brac.2013.10

To link this article: http://dx.doi.org/10.4471/brac.2013.10

\section{PLEASE SCROLL DOWN FOR ARTICLE}

The terms and conditions of use are related to the Open Journal System and to Creative Commons Non-Commercial and Non-Derivative License. 
BRAC - Barcelona Research Art Creation. Vol. 1 No. 2, October 2013

pp. 228-230

\section{Reviews (I)}

Boncompte, C. (2009). Iconografia picassiana (1905-1907). Influencia de la pintura pompeiana. (Tesis doctoral no publicada). Universitat de Barcelona, España.

La personalitat de Pablo Picasso es una de les més estudiades a la història de l'art, Per aquest motiu són destacables els estudis que hi ha dedicat la Dra. Conxita Boncompte, una aportació que te, a més el valor afegit, que és el resultat d'una tesi doctoral presentada a la Universitat de Barcelona. El llarg article, 24 pàgines de text amb 108 notes documentals, ha estat publicat a revista Goya, editada per la Fundación Lázaro Galdeano de Madrid, i una de les més prestigioses en llengua castellana en Història de l'Art.

Conxita Boncompte, l'autora, és pintora i crítica d'art. Va estudiar la carrera de dret entre 1974 i 1979 i, el 1994, va optar per replantejar-se la seva orientació professional cap a la recerca en història de l'art amb l'objectiu de justificar des d'un punt de vista teòric la seva inicial - i molt prematura- vocació plàstica. Va cursar la llicenciatura de Geografia i Història fent l'especialitat de Història de l'Art i va obtenir el Diploma d'Estudis Avançats DEA, el 2004. El 2009 va defensar la seva tesi doctoral sota la direcció de la Dra. Lourdes Cirlot.

La gran contribució de Boncompte a la història de l'art- i en concret, als estudis picassians és, precisament, aportar a la visió de la pintura la seva perspectiva d'artista en actiu. La pràctica de la pintura desperta una sensibilitat especial, una manera de veure que, a voltes, ens manca als

2013 Hipatia Press

ISSN 2014-8992

DOI: $10.4471 /$ brac. 2013.10

Hipatia Press

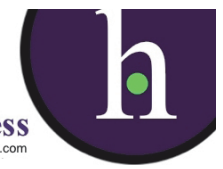


historiadors. L'origen de la tesi va sorgir d'una intuïció - un estat molt pròxim a la creació, al cap i la fi- que després va tenir el coratge d'anar desenvolupant de manera paral•lela als grans estudis sobre aquest període de Picasso. El període estudiat per Boncompte es correspon amb l'etapa picassiana que es coneix com Época rosa, la primera etapa francesa de Picasso, un cop bandejada la barcelonina Època blava. Un dels moments claus dels anys roses, va ser l'estada que el pintor va fer a Gósol, un petit poble del Pirineu, entre el mesos de maig i agost de 1906. Hi ha abundosa bibliografia però, cal admetre, que els investigadors estrangers no coneixen ni entenen Gósol, ni el seu paisatge amb el canvis d'hivern a estiu i, menys encara, les seves tradicions i costums. Entre els investigadors catalans a, més del clàssic estudi de Josep Plau i Fabre, hi han fet aportacions de Claustre Rafart, Jessica Jaques Pi i Mercè Vidal Jansà. Boncompte hi afegeix un acurat estudi de la iconografia de les pintures i el seguiment de la vida de les imatges que conformen l'imaginari de Picasso en aquell moment.

La gran aportació del treball resideix en que ha plantejat una nova mirada sobre el pas de l'època blava a l'època rosa de Picasso. L'autora profunditza en l'entorn cultural de l'artista tant a Barcelona com a París, tot defensant la importància de la influència de les pintures pompeianes en la producció d'aquest període- abans doncs, del viatge de l'any 1917, un moment que la seva vida gravitava a l'entorn d'Olga Koklova i els Ballets Russos. Més enllà encara, hi veu també traces de les més profundes arrels locals, tant en els costums i tradicions com en l'observació de la imatge de la Mare de Deu de Gòsol del segle XII -ara conservada al MNAC però venerada encara in situ a inicis del segle $\mathrm{XX}$-. Si, be les pintures pompeianes eren conegudes en l'entorn culte en el que es movia el jove Picasso a París; a inicis del segle XX, encara es qualificava el romànic com "art bàrbar", encara no s'havien descobert les pintures murals del Pirineu i tot l'interès dels col•leccionistes es centrava en el que, ara, coneixem com art gòtic.

A l'actualitat, l'autora continua investigant sobre Picasso i te com a objectiu preparar una exposició que li permeti mostrar les seves hipòtesis de treball. L'article que comentem parteix, com he dit, d'una primera intuïció, però després una recerca acurada, ha arribat a unes sòlides conclusions que amplien, sens cap dubte, els coneixements sobre 
230 Freixa, M. - Iconografia picassiana (1905-1907)

Picasso. I, sempre, i això és també un aspecte cal considerar, ha estat treballat amb entusiasme.

Mireia Freixa, Universitat de Barcelona mireia.freixa@ub.edu 